\title{
Stratigraphy, Petrology, and Depositional Environment of the Kenwood Siltstone Member, Borden Formation (Mississippian), Kentucky and Indiana
}

GEOLOGICAL SURVEY PROFESSIONAL PAPER 1007

Prepared in cooperation with the

Kentucky Geological Survey 


\section{Stratigraphy, Petrology, and Depositional Environment of the Kenwood Siltstone Member, Borden Formation (Mississippian), Kentucky and Indiana}

By ROY C. KEPFERLE

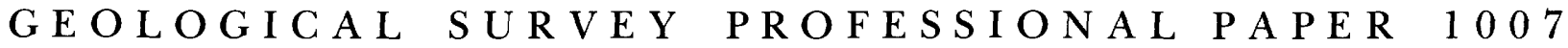

Prepared in cooperation with the Kentucky Geological Survey

Paleocurrents, trace fossils, and facies analysis of a vertical profile through a terrigenous clastic sequence are combined to determine the paleogeography for a part

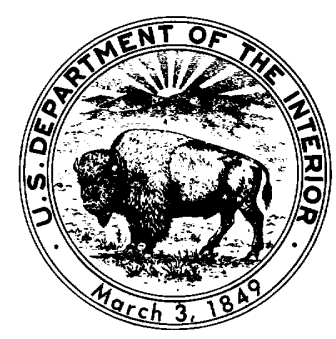
of the Lower Mississippian 


\title{
UNITED STATES DEPARTMENT OF THE INTERIOR
}

\author{
CECIL D. ANDRUS, Secretary
}

\section{GEOLOGICAL SURVEY}

\author{
V. E. McKelvey, Director
}

Library of Congress Cataloging in Publication Data

Kepferle, Roy Clark, 1926-

Stratigraphy, petrology, and depositional environment of the Kenwood Siltstone Member, Borden Formation (Mississippian), Kentucky and Indiana.

(Geological Survey professional Paper 1007)

Bibliography: p. 47-49.

Supt. of Docs. No.: I 19.16:1007

1. Geology, Stratigraphic-Mississippian. 2. Siltstone--Kentucky. 3. Siltstone--Indiana. 4. Geology-Kentucky.

5. Geology--Indiana. I. Kentucky. Geological Survey. II. Title: Stratigraphy, petrology, and depositional environment of the Kenwood Siltstone Member. III. Series: United States. Geological Survey. Professional Paper 1007.

QE471.15.S54K46

$551.7^{\prime} 51^{\prime} 09769$

$76-608334$

For sale by the Superintendent of Documents, U.S. Government Printing Office

Washington, D.C. 20402

Stock Number 024-001-02994-4 


\section{CONTENTS}

\begin{tabular}{|c|c|c|c|}
\hline & Page & & Page \\
\hline Abstract & 1 & Paleocurrent analysis & 25 \\
\hline Introduction & 1 & Provenance & \\
\hline Acknowledgments & 1 & Depositional model & \\
\hline Review of previous work & 1 & Evidence from stratigraphy & \\
\hline General stratigraphy of Borden Formation & 2 & Evidence from petrology & \\
\hline Stratigraphy of the Kenwood Siltstone Member & 7 & Evidence from bedding structures & \\
\hline Size and shape & 7 & Basin geometry & \\
\hline Bedding of siltstone & 7 & Subsea fan model & \\
\hline Siltstone content & 7 & Triggering mechanism of the turbidity currents & \\
\hline Petrology & 10 & Facies analysis and the vertical profile & \\
\hline Composition & 11 & Environments of deposition & \\
\hline Siltstone & 11 & Basin-floor environment & \\
\hline Clay mineralogy & 18 & Base-of-slope environment & \\
\hline Texture & 18 & Slope environment & \\
\hline Siltstone & 18 & Platform environment & \\
\hline al environment indicators & $\begin{array}{l}18 \\
18\end{array}$ & Erosional phase and depositional hiatus & \\
\hline uctures & 18 & Carbonate platform environment & \\
\hline Inter & 20 & The paleoslope and paleotectonics & \\
\hline External sedimentary structures & 23 & References cited & \\
\hline
\end{tabular}

\section{ILLUSTRATIONS}

FIGURE 1. Index map of north-central Kentucky and adjacent Indiana

2. Columnar section of the Borden Formation

3. Correlation chart of stratigraphic nomenclature, Kentucky and Indiana

4. Diagrammatic cross section showing relation of Borden to Fort Payne

5-8. Maps showing:

5. Areal extent of Borden delta front

6. Area underlain by Kenwood Siltstone Member

7. Thickness of the Kenwood Siltstone Member

8. Thickness of interval between base of Kenwood and base of Borden

9. Fence diagrams of Kenwood

11. Photographs showing thick beds in the Kenwood

12. Map showing thickness of thickest siltstone bed in Kenwood

13. Diagrammatic cross sections of channel-fill types in the Kenwood

14. Map showing siltstone:shale isoratios of the Kenwood

15. Photomicrograph of basal contact, bed 2, Kenwood Hill

16. Pie diagrams of modal composition of Kenwood

17. Diagram showing composition of siltstone of members of Borden

18. Photomicrographs of siltstone of the Kenwood

19. X-ray diffractometer traces of typical Kenwood sample

20. X-ray diffractometer traces of clay from Kenwood

21. Triangular-plot textural analyses of the Kenwood

22. Grain-size histogram in typical siltstone of the Kenwood

23. Columnar section of Kenwood type locality showing vertical variation

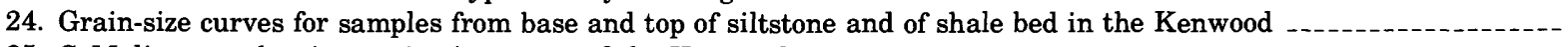

25. C-M diagram showing grain-size image of the Kenwood

26-29. Photographs showing:

26. Planar lamination in siltstone of the Kenwood

27. Internal bedding sequences in siltstone beds along Firetower Hill Road

28. Siltstone bed in the Kenwood along Pleiss Hollow

29. Sideritic "ironstone" concretions in Kenwood 
Figure 30. Diagrams showing flow regime related to structures in turbidite 31-35. Photographs showing:

31. Sole marks on the siltstone beds of the Kenwood

32. Trace fossils

33. Trace fossils of Pascichnia affinities

34. Trace fossil Chondrites sp

35. Trace fossils of Fodinichnia affinities

36. Diagrammatic classification of the trace fossils

37. Diagrammatic ichnocoenose of the Borden delta front

38. Map and histogram of paleocurrent lineations and vectors, Kenwood

39. Sketch map showing paleocurrents in the Borden Formation in Kentucky

40. Diagrams showing variation of internal bedding sequence in turbidites

41. Vertical profile and facies analysis of Borden Formation

42. Block diagrams showing depositional environments

43. Paleogeographic diagram of eastern interior

\section{TABLES}

1. Modal analyses of thin sections of siltstones of the Borden Formation

2. Statistical parameters for textural analysis of the Kenwood Siltstone Member of the Borden Formation

3. Linear directional indicators in the Kenwood Siltstone Member of the Borden Formation Siltstone Member of the Borden Formation

5. Comparison of proximal and distal turbidites, Kenwood Siltstone Member of the Borden Formation

6. Characteristics of modern and ancient subsea fans relative to the Kenwood Siltstone Member of the Borden Formation

7. Triggering mechanisms of turbidity currents, Kenwood Siltstone Member of the Borden Formation 


\title{
STRATIGRAPHY, PETROLOGY, AND DEPOSITIONAL ENVIRONMENT OF THE KENWOOD SILTSTONE MEMBER, BORDEN FORMATION (MISSISSIPPIAN), KENTUGKY AND INDIANA
}

\author{
By Roy C. KePferle
}

\begin{abstract}
The Kenwood Siltstone Member of the Borden Formation (Mississippian) is a wedge of sediment that thins from $110 \mathrm{ft}(33.5 \mathrm{~m})$ to zero across a width of $10 \mathrm{mi}(16 \mathrm{~km})$ and that extends for $50 \mathrm{mi}(80 \mathrm{~km})$ along depositional strike from southern Indiana southeastward into north-central Kentucky.

Detailed petrologic analysis of the Kenwood discloses two rock types: an illitic clay to silt shale and a clayey siltstone, illite-arkose to illite-subarkose. The shale is similar to that of the New Providence Shale Member of the Borden Formation on which it lies or locally intertongues. The siltstone is poorly sorted, immature, and medium grained. Cumulative grain-size curves are strongly fine skewed and leptokurtic. Textural data plotted on a C-M diagram fall near the fine end of the turbidite field and in the field for pelagic suspension.

Internal bedding sequences are characterized by planar-bedding laminae but locally include the complete Bouma-sequence. Sole marks consist mainly of grooves and trace fossils.

Paleocurrents were generally west-southwest in water depth postulated as circalittoral $(150-600 \mathrm{ft}$, or $46-180 \mathrm{~m})$. Such paleocurrents, considered with a coarsening-upward vertical profile through the Nancy and Holtsclaw Siltstone Members of the Borden Formation, suggest that the siltstone beds of the Kenwood were deposited as a turbidite sequence that fanned out from two centers along the front of a prograding platform of sediment. The front of this platform marks the outer edge of the Catskill-Pocono delta system that began building westward in Late Devonian time. The end of the westward progradation is recorded by a widespread, burrowed, glauconitestrewn surface on the sediment platform. The glauconite probably originated during a depositional hiatus in Kentucky and Indiana after the final stages of the Acadian orogeny in the east.
\end{abstract}

\section{INTRODUCTION}

The Kenwood Siltstone Member in the lower part of the Borden Formation is fairly well exposed and crops out in a relatively small area (fig. 1). It is a turbidite sequence in which individual beds are timestratigraphic units that show paleocurrent directions. This report presents a depositional model for the Kenwood based on the interpretation of its shape and physical relations, paleocurrent markings, bedding, and trace fossils. This model, in combination with a facies analysis of the whole Borden Formation in the study area, is used to construct a picture of the paleogeography of the region in the Early Mississippian.

\section{ACKNOWLEDGMENTS}

Support for part of the fieldwork and travel was furnished by a Penrose Grant from the Geological Society of America. The Indiana Geological Survey courteously furnished access to stratigraphic information in their files. I am indebted to many of my colleagues in the U.S. Geological Survey, particularly to Warren L. Peterson, who also recognized the Borden delta front in central Kentucky and whose discussions helped develop my concepts of depositional environments. Prof. Wayne A. Pryor and Prof. Paul Edwin Potter, University of Cincinnati, encouraged me to undertake the study. I benefited from visits to the outcrop area with Prof. Francis J. Pettijohn, Dr. Alan F. Thomson, and students from Johns Hopkins University. This report is based on part of a dissertation submitted June 1972 to the University of Cincinnati, Cincinnati, Ohio, in partial fulfillment of the requirements for the degree of Doctor of Philosophy.

\section{REVIEW OF PREVIOUS WORK}

Early stratigraphic and paleontologic studies in the Lower Mississippian rocks of the region were summarized by Butts (1922) and Stockdale (1931, 1939). Butts discussed the Lower Mississippian rocks in eastern Kentucky in some detail, touched on relationships with the rest of the State, and attempted correlations with southern Indiana. Stockdale's early detailed study in Indiana was later expanded to unify the correlations of the Lower Mississippian rocks in Kentucky and Ohio. For 20 years after Stockdale's work, studies of the Borden were chiefly paleontologic (Gutschick, 1954; Conkin, 1954, 1956, 1957, 1960).

Recent detailed geologic mapping in Kentucky has led to a redefinition of the Borden and some of its subdivisions (Weir and others, 1966; Sable and others, 1966; Weir, 1970; Kepferle, 1971) and to reinterpretations of some of the depositional environments of some Mississippian units (Thaden and others, 1961; Sedimentation Seminar, 1969, 1972; Moore and Clarke, 


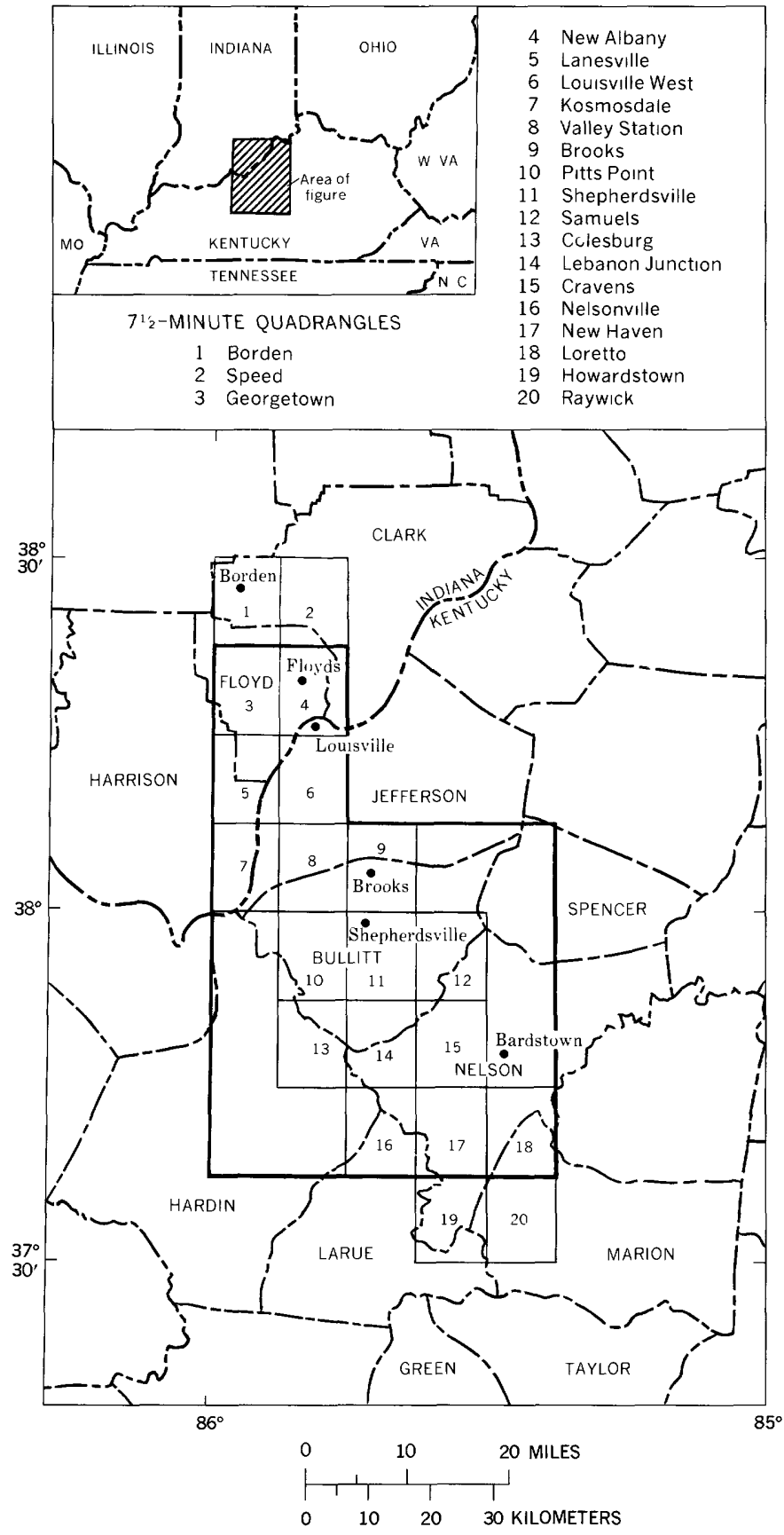

FiguRE 1.-Index map of study area in part of north-central Kentucky and adjacent Indiana, showing counties and quadrangles referred to in text. Heavy line outlines area of figures $6,7,8,12$, 14 , and 38.

1970; Peterson and Kepferle, 1970; Kearby, 1971; Pryor and others, 1974).

In Indiana, stratigraphic relations and depositional environments of the upper part of the Borden have been restudied by Smith (1965), Whitehead (1973, 1976), Lane (1973), Nicoll and Rexroad (1975), and students at the University of Indiana (Suttner and
Hattin, 1973). In Illinois, important contributions to interpretation of depositional environments in Borden equivalents have been made by studies of subsurface data (Swann and others, 1965; Lineback, 1966, 1968a, 1969).

\section{GENERAL STRATIGRAPHY OF BORDEN FORMATION}

The Borden Formation is a complex sequence of dominantly terrigenous clastic rocks. In the central part of the study area, the general sequence is as follows, in ascending stratigraphic order: the New Providence Shale, the Kenwood Siltstone, the Nancy, the Holtsclaw Siltstone, and the Muldraugh Members (figs. 2, 3). The Floyds Knob Formation as used by Stockdale (1939, p. 191-200) is herein called the Floyds Knob Bed and is included as the basal part of the Muldraugh Member. Some members intertongue and intergrade with others. For example, the Kenwood Siltstone Member descends stratigraphically and intertongues with the New Providence Shale Member; similarly, the Holtsclaw Siltstone Member descends and grades out into the Nancy Member (fig. 4).

The Borden Formation in most of the study area overlies the New Albany Shale, an olive-black to grayish-black, silty, carbon-rich shale. In most of Indiana and locally in northern Kentucky (Conkin and Conkin, 1972; Kepferle, 1974), the two are separated by the Rockford Limestone, a single thin bed of greenish-gray to olive-gray, ferruginous, glauconitic, micrograined dolomitic limestone.

The New Providence Shale Member, the basal member of the Borden Formation, is mainly mediumgray to olive-gray silty clay shale, which weathers light greenish gray or yellowish gray. It is obscurely laminated. In fresh exposures, parting is commonly hackly and uneven to subconchoidal. Abundant to rare siderite concretions locally stand out along some bedding planes. Minor constituents are rare phosphate nodules and discontinuous thin beds and stringers of crinoidal limestone. The thickness of the New Providence ranges from 90 to $220 \mathrm{ft}(27.4-67 \mathrm{~m})$ in the study area. Fossils in the New Providence include brachiopods, crinoid plates, bryozoans, small horn corals, auloporid corals, foraminifers, and trace fossils. Biostratigraphic subdivisions of the New Providence (Conkin, 1957) have no apparent lithostratigraphic counterparts.

The Kenwood Siltstone Member, which consists of interbedded siltstone and shale, overlies and locally intertongues with the New Providence Shale Member. The thickness of the member is generally less than 40 $\mathrm{ft}(12.2 \mathrm{~m})$ but locally reaches $110 \mathrm{ft}(33.5 \mathrm{~m})$.

The Nancy Member (Weir and others, 1966) directly 


\begin{tabular}{|c|c|c|c|c|}
\hline 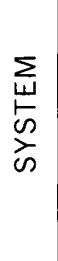 & 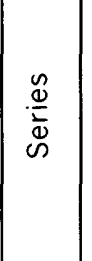 & $\begin{array}{l}\text { FORMATION, } \\
\text { MEMBER, } \\
\text { AND BED }\end{array}$ & $\begin{array}{l}\text { LITHOLOGY } \\
\text { AND } \\
\text { THICKNESS } \\
\text { IN FEET } \\
\text { (METERS) }\end{array}$ & DESCRIPTION \\
\hline \multirow{7}{*}{$\begin{array}{l}z \\
\frac{1}{0} \\
\frac{2}{\infty} \\
\frac{N}{5} \\
\frac{N}{\Sigma}\end{array}$} & \multirow{7}{*}{ 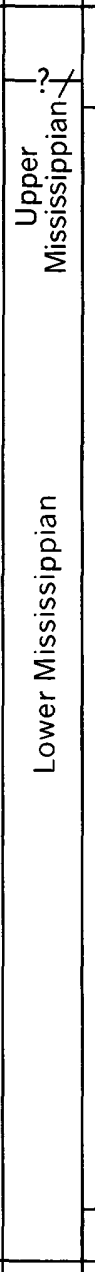 } & $\begin{array}{l}\text { Harrodsburg } \\
\text { Limestone }\end{array}$ & 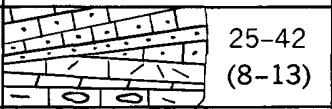 & $\begin{array}{l}\text { Limestone, dolomitic in part, and chert. Crinoidal } \\
\text { biosparrudite. }\end{array}$ \\
\hline & & $\begin{array}{c}\text { Muldraugh } \\
\text { Member } \\
\begin{array}{c}\text { Floyds Knob } \\
\text { Bed }\end{array} \\
\end{array}$ & (6-18) & $\begin{array}{l}\text { Limestone, dolomite, and chert; silty, geodal; } \\
\text { glauconitic at base; resistant. }\end{array}$ \\
\hline & & $\begin{array}{l}\text { Holtsclaw } \\
\text { Siltstone } \\
\text { Member }\end{array}$ & 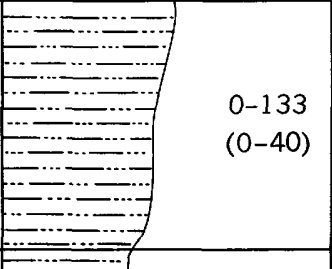 & $\begin{array}{l}\text { Siltstone, argillaceous, calcareous in part. } \\
\text { Brachiopods, trilobites. Calcareous concretions } \\
\text { common near top; resistant. }\end{array}$ \\
\hline & & $\begin{array}{l}\text { Nancy } \\
\text { Member }\end{array}$ & 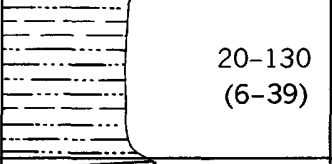 & $\begin{array}{l}\text { Shale, silty, argillaceous, abundant trace fossils; } \\
\text { moderately resistant. }\end{array}$ \\
\hline & & 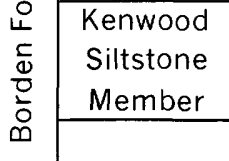 & 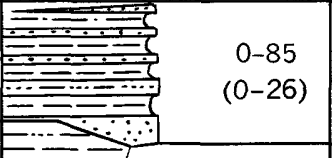 & $\begin{array}{l}\text { Siltstone, tabular, very thin to thick beds, resistant; } \\
\text { alternating with shale similar to that in unit be- } \\
\text { low. Abundant trace fossils. }\end{array}$ \\
\hline & & $\begin{array}{c}\text { New } \\
\text { Providence } \\
\text { Shale } \\
\text { Member }\end{array}$ & 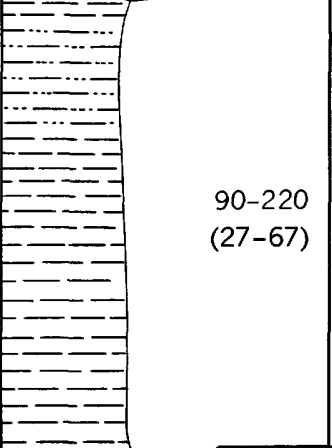 & $\begin{array}{l}\text { Shale, argillaceous, silty; increasing clay toward } \\
\text { base, phosphate nodules at base. Scattered } \\
\text { siderite ironstone nodules; rare fossils, other } \\
\text { than trace fossils; poorly resistant. }\end{array}$ \\
\hline & & $\begin{array}{l}\text { Rockford } \\
\text { Limestone }\end{array}$ & $0-3(0-1)$ & Limestone, thin, dense, gray; sparse in Kentucky. \\
\hline $\begin{array}{l}z \\
\sum \\
\vdots \\
\\
\end{array}$ & 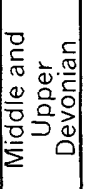 & $\begin{array}{l}\text { New Albany } \\
\text { Shale }\end{array}$ & 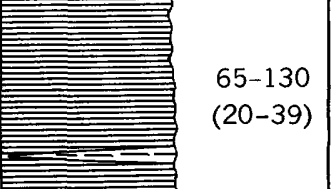 & $\begin{array}{l}\text { Shale, silty, olive-black to grayish- black, pyritic; } \\
\text { phosphate nodules in upper part. thin gray } \\
\text { shale seams near base; fissile; carbonaceous. } \\
\text { Callixylon newberryi. }\end{array}$ \\
\hline
\end{tabular}

FIGURE 2.-Generalized columnar section of the Borden Formation in north-central Kentucky.

overlies the Kenwood in easternmost exposures and to the west overlies the New Providence Shale Member (fig. 4). The Nancy is dominantly olive-gray to medium-gray clayey silt shale and ranges in thickness in the study area from 20 to $190 \mathrm{ft}(6.1-57.8 \mathrm{~m})$. Strata equivalent to the Nancy Member in Indiana include part of the Locust Point Formation and possibly some of the lower part of the Carwood Formation (fig. 3). Fossils in the Nancy include abundant "curly" trace- fossil markings along the bedding and, in rare calcareous zones, crinoid columnals, bryozoans, and brachiopods.

The Holtsclaw Siltstone Member (Kepferle, 1971) overlies the Nancy Member in easternmost exposures and intertongues with the Nancy to the west in Jefferson and Bullitt Counties, Ky. (fig. 4). In Indiana, strata equivalent to the Holtsclaw are in the Carwood Formation (fig. 3). The Holtsclaw is medium-dark-gray to 
KENTUCKY

This report
INDIANA

(Smith, 1965; Stockdale, 1939; Lineback, 1968b)

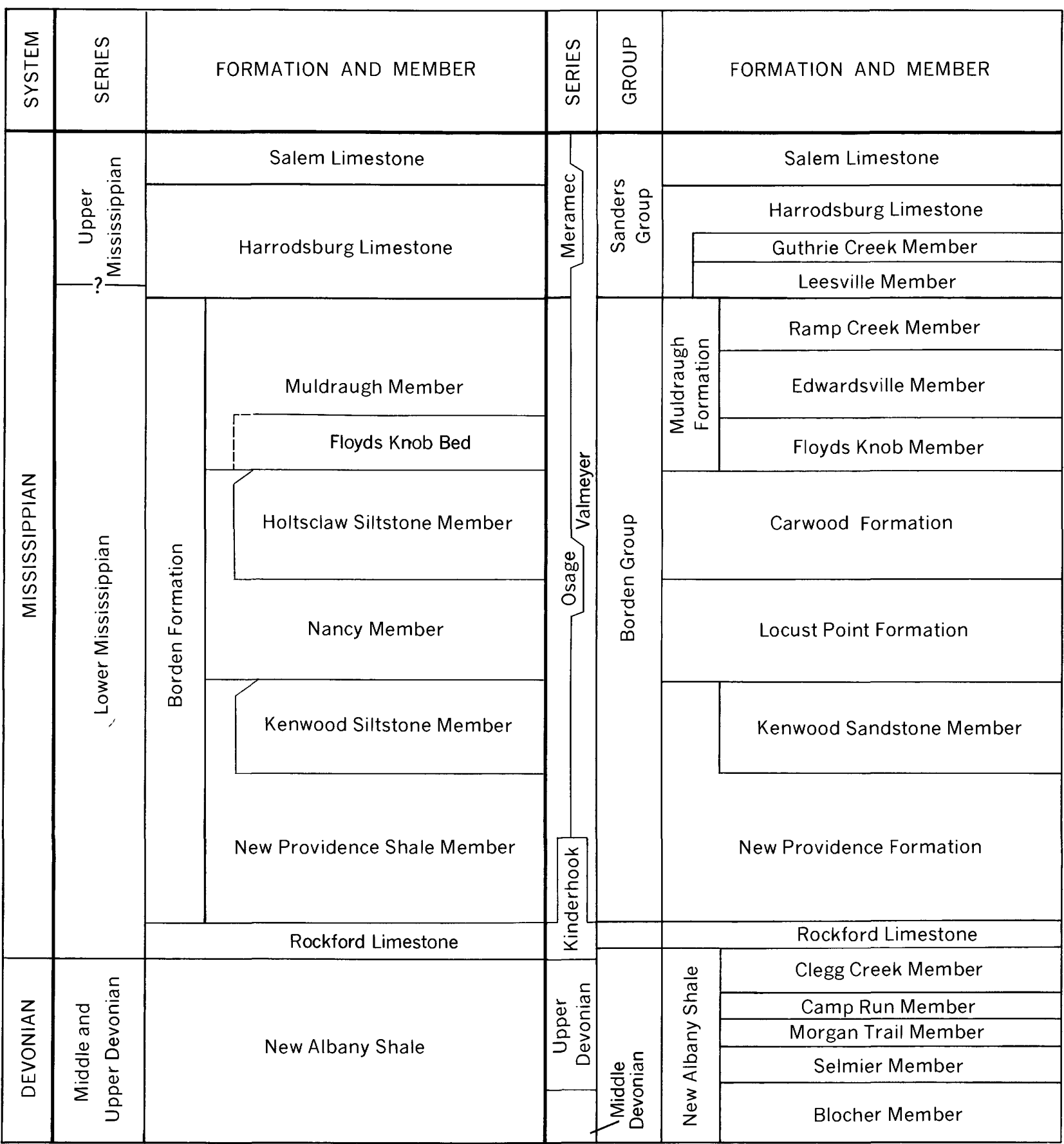

FIGURE 3.-Correlation chart comparing stratigraphic nomencl ature of the Louisville area, Kentucky, with that used in southern Indiana. (The boundary between the Borden and Sanders Groups in Indiana has been redefined recently by Nicoll and Rexroad (1975, pl. 2). This redefinition does not affect the data presented in this report.)

dark-gray siltstone, which weathers olive gray to yellowish gray. The thickness of the Holtsclaw reaches about $130 \mathrm{ft}(39.6 \mathrm{~m})$. The upper $20 \mathrm{ft}(6.1 \mathrm{~m})$ is slightly coarser grained and is extensively bioturbated.
Brachiopods, gastropods, trilobites, and bryozoans are locally abundant, commonly as molds.

The complex of the Nancy and Holtsclaw is overlain by a silty glauconitic unit here called the Floyds Knob 


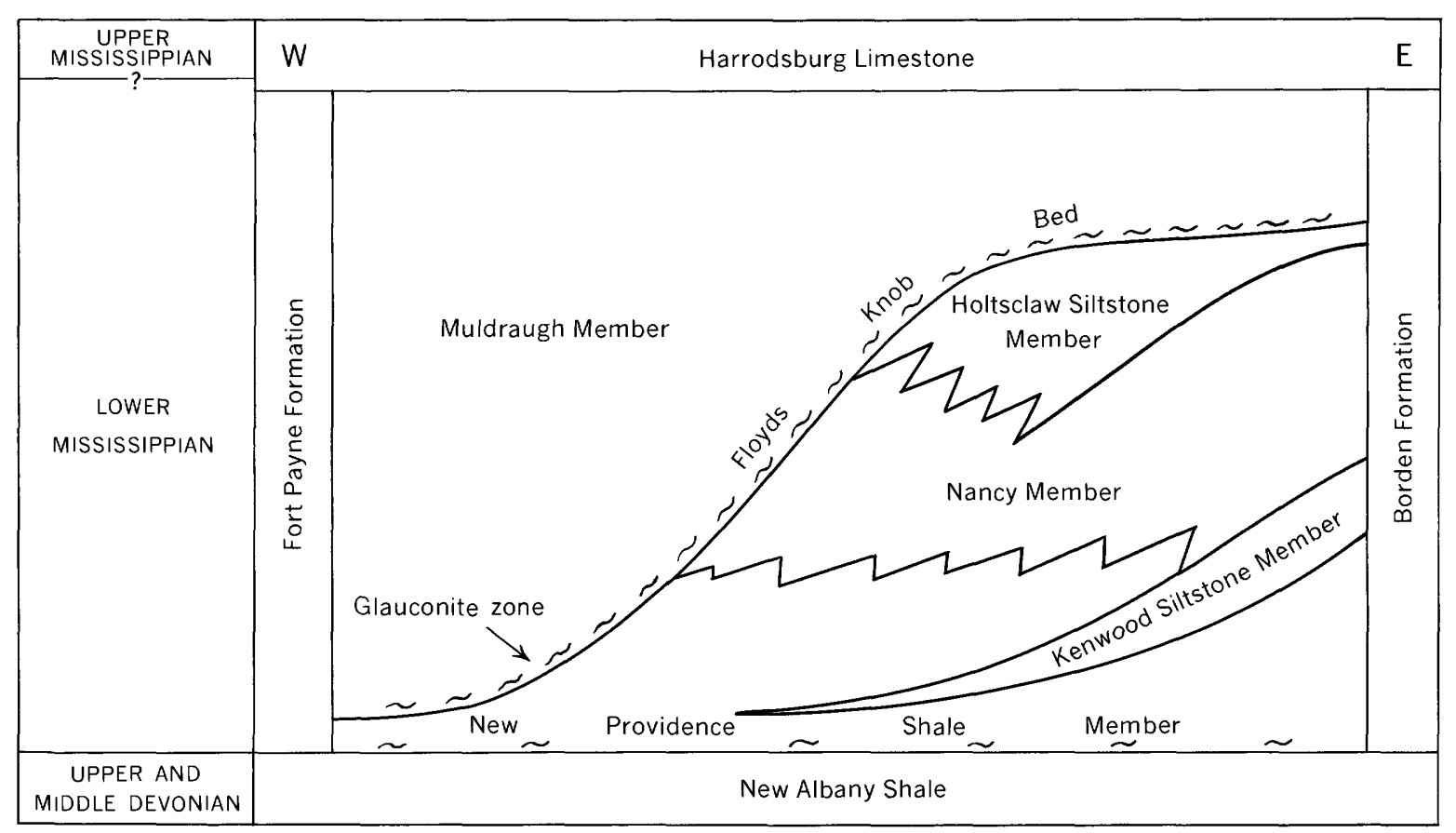

FIGURE 4.-Diagrammatic cross section showing general relation of subdivisions of the Borden in the Louisville area to the Fort Payne Formation of central Kentucky.

Bed. This bed is nearly everywhere marked by a conspicuous basal layer and a less prominent upper layer of greenish-black glauconitic silt. The layers locally coalesce but commonly are separated by $5-18 \mathrm{ft}$ $(1.5-5.5 \mathrm{~m})$ of phosphatic, siliceous silty dolomite, dolosiltstone, clayey siltstone, or brownish-grey oolitic limestone. The bed contains abundant foraminifers (Conkin, 1954, 1960) and locally abundant pelmatozoans, brachiopods, and bryozoans. Because this glauconitic zone is thin, it has been for the most part mapped with the Muldraugh Member.

The Muldraugh is the uppermost member of the Borden in the area. It consists of olive-gray to medium-dark-gray dolomitic siltstone, dolosiltstone, and silty dolomite, irregularly interbedded with medium- to light-gray, coarse crinoidal limestones. Chert and siliceous geodes are common and locally accentuate a "knotty" mottled appearance of the outcrop. The thickness in the study area ranges from $20-60 \mathrm{ft}$ (6.1-18.3 m). Bryozoans, crinoid columnals, sponge spicules, and brachiopods are locally common.

The Edwardsville has been included as a member in the lower part of the Muldraugh Formation in Indiana by Smith (1965) and Whitehead $(1973,1976)$ and is now considered by Nicoll and Rexroad (1975) as the uppermost formation in the Borden Group. It is missing or is in part equivalent to the Floyds Knob Bed in Kentucky (fig. 3).
The Harrodsburg Limestone overlies the Borden throughout a broad area in southwestern Indiana and west-central Kentucky, including the study area (figs. 3, 4). The Harrodsburg is a sparsely glauconitic, light-gray to light-olive-gray crinoidal limestone with a matrix that ranges from sparry clear crystalline calcite to micritic calcite. Scattered grains of glauconite and the sparry matrix of the Harrodsburg distinguish it from the crinoidal limestone of the Borden.

The lithology of the Borden Formation changes a few miles southwest of the western extent of the Kenwood. This change is marked by an incomplete termination of the dominantly terrigenous clastic siltstone and shale facies that constitute the main part of the Borden to the north and east and by a southwestward thickening of the dolomitic, calcareous, siliceous facies characteristic of both the Fort Payne Formation and the Muldraugh Member of the Borden (fig. 4). This narrow area of rapid stratigraphic change has been called the "Borden delta front" (Peterson and Kepferle, 1970, fig. 4). The strike of the front (fig. 5) is projected in subsurface to the northwest into central Indiana, where it coincides with the $100-\mathrm{ft}$ isopach line of the Borden siltstone delta of Swann, Lineback, and Frund (1965). On the basis of detailed surface mapping, the front is thought to extend southeastward at least as far as the Elk Valley area of Tennessee (Englund, 1968, p. 10 11). The position of the front is thought to influence 

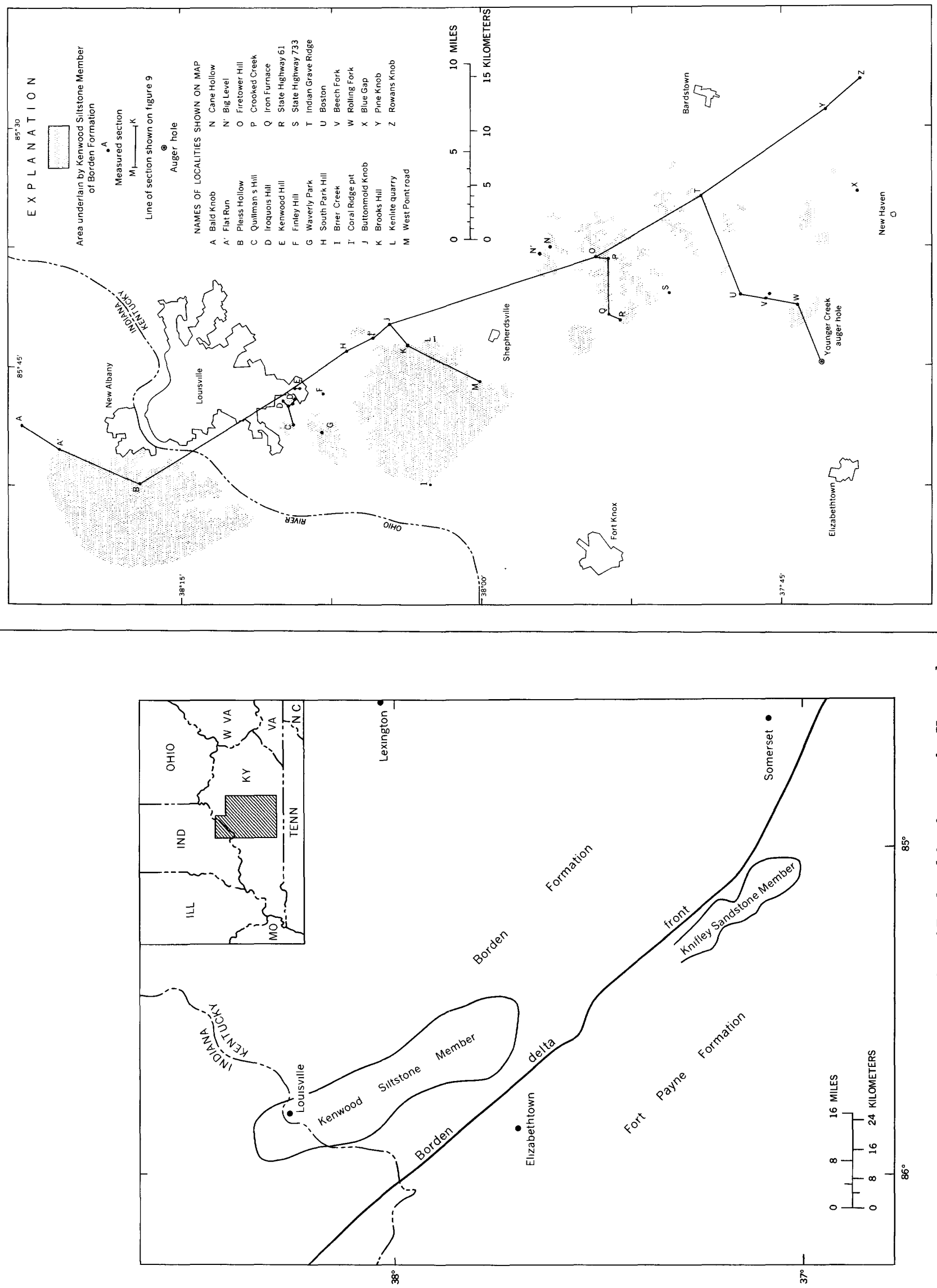

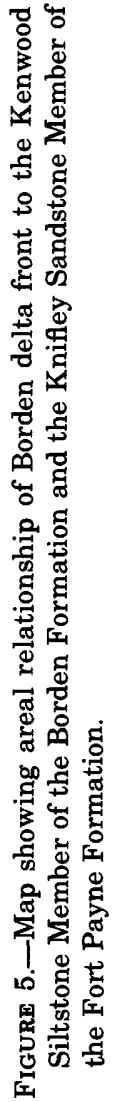


depositional patterns in units such as the Knifley Sandstone Member of the Fort Payne Formation (fig. 5; Sedimentation Seminar, 1972).

\section{STRATIGRAPHY OF THE KENWOOD SILTSTONE MEMBER}

The Kenwood was named by Butts $(1915$, p. 148) for exposures of interbedded siltstone and shale on Kenwood Hill in the southern part of the city of Louisville, Jefferson County, Ky. (loc. E, fig. 6). Minor revisions of the original definition were made by Stockdale (1939, p. 109-111) and Kepferle (1972b). Detailed mapping, including that of Peterson (1966a, b, 1967, 1968, 1972), shows that the member is more extensive and generally thicker than previously recognized. Significant exposures, for which complete measured sections of the Kenwood are described separately (Kepferle, 1972c), are shown on figure 6.

Siltstone characterizes the Kenwood, even though shale is the dominant lithology. The siltstone, where freshly exposed, is medium gray to medium dark gray; it weathers medium light gray to light olive gray or yellowish gray and is commonly limonite stained to a dark yellowish orange. The shale, like the New Providence, is dark greenish gray, dark to medium gray, and olive gray to grayish green where fresh, and it weathers yellowish gray to light greenish gray.

\section{SIZE AND SHAPE}

The Kenwood is an irregular wedge-shaped body about $50 \mathrm{mi}(80 \mathrm{~km})$ long and $10 \mathrm{mi}(16 \mathrm{~km})$ wide (fig. 7) which dips gently southwestward to its pinchout and which has lost much of its thick northeastern edge to erosion (fig. 8). The Kenwood is thick in two areas along the eastern margin of the study area (fig. 7). The area of greatest thickness is the eastern part of the Shepherdsville quadrangle, Bullitt County, Ky., where the Kenwood is $110 \mathrm{ft}(33.5 \mathrm{~m})$ thick. The other area is north, in Brooks and Louisville West quadrangles, Jefferson County, Ky., where the Kenwood is $65 \mathrm{ft}$ $(19.8 \mathrm{~m})$ thick.

The depositional dip of the Kenwood Siltstone Member ranges from about 5 to $20 \mathrm{ft} / \mathrm{mi}(0.9-3.7 \mathrm{~m} / \mathrm{km})$ relative to the base of the Borden (figs. 8,9 ).

\section{BEDDING OF SILTSTONE}

The siltstone beds in the Kenwood are moderately indurated and form ribbed slopes and gullys in contrast to the less indurated more easily weathered shale. Most beds are planar and tend to maintain their thickness over the length of most exposures, which is seldom more than a few tens of feet long. The bed thickness ranges from less than 0.1 to $20 \mathrm{ft}(3 \mathrm{~cm}-6.1 \mathrm{~m})$, and the graphic mean thickness is $0.7 \mathrm{ft}(21.6 \mathrm{~cm})$ as determined in much the same manner recommended for determining grain-size parameters (Folk, 1968, p. 44-50). (See fig. 10.) The thicker beds, such as those shown in figure 11, are generally found in the easternmost areas of outcrop (fig. 12). Rare examples of large differences of thickness in short distances are for the most part related to the accumulation or compounding of thicker beds in probable channel fills.

In channel fills.-Channel fills of the Kenwood are divided into three types on the basis of thickness, number, and geometry of the siltstone beds in the fill. Type $I$ is shallow, narrow, and restricted to a single siltstone bed, whose top is planar (fig. 13a). Type II is filled with siltstone beds that are thicker than beds outside the channel and whose tops are planar (fig. 13b). Type III consists of several inclined siltstone beds that tend to coalesce towards the center of the channel (fig. 13c). Thick beds in a type III channel fill that are replaced by shale are interpreted as rescour (fig. 13d). Theoretically, rescour could remove beds of type I or type II channels, but I know of no examples from the study area. In all the channel fills, sole marks on the basal beds are absent.

Distribution of siltstone beds in vertical section.Siltstone beds in the Kenwood occur singly and in packages of several beds. The packages are continuous over greater distances than individual beds and thus are useful markers in studying the Kenwood. These packages may be grouped into three classes according to the arrangement of thick and thin beds in the package as suggested by Thomson (1971). Class I packages, characterized by thicker beds, possibly composite beds, appearing in the base of the package, are in a narrow band on the east margin of the area of outcrop. Class II packages, characterized by thicker composite beds in the middle of the package, are just west of the eastern outcrops. Class III packages, characterized by mainly separate beds, occupy the remainder and largest part of the area.

The number of siltstone beds is greater in the easternmost belt of outcrops than in the remainder of the area. Field observations suggest that the member, on average, contains about six to eight siltstone beds. At the featheredges, however, the Kenwood is a single siltstone bed. Where the member is thick, beds are more numerous; on the south end of Indian Grave Ridge in Nelson County, Ky. (loc. T, fig. 6), it contains as many as 37 individual siltstone beds.

\section{SILTSTONE CONTENT}

The siltstone content of the Kenwood decreases fairly regularly westward (fig. 14). The area containing the greatest percentage of siltstone is along the east 

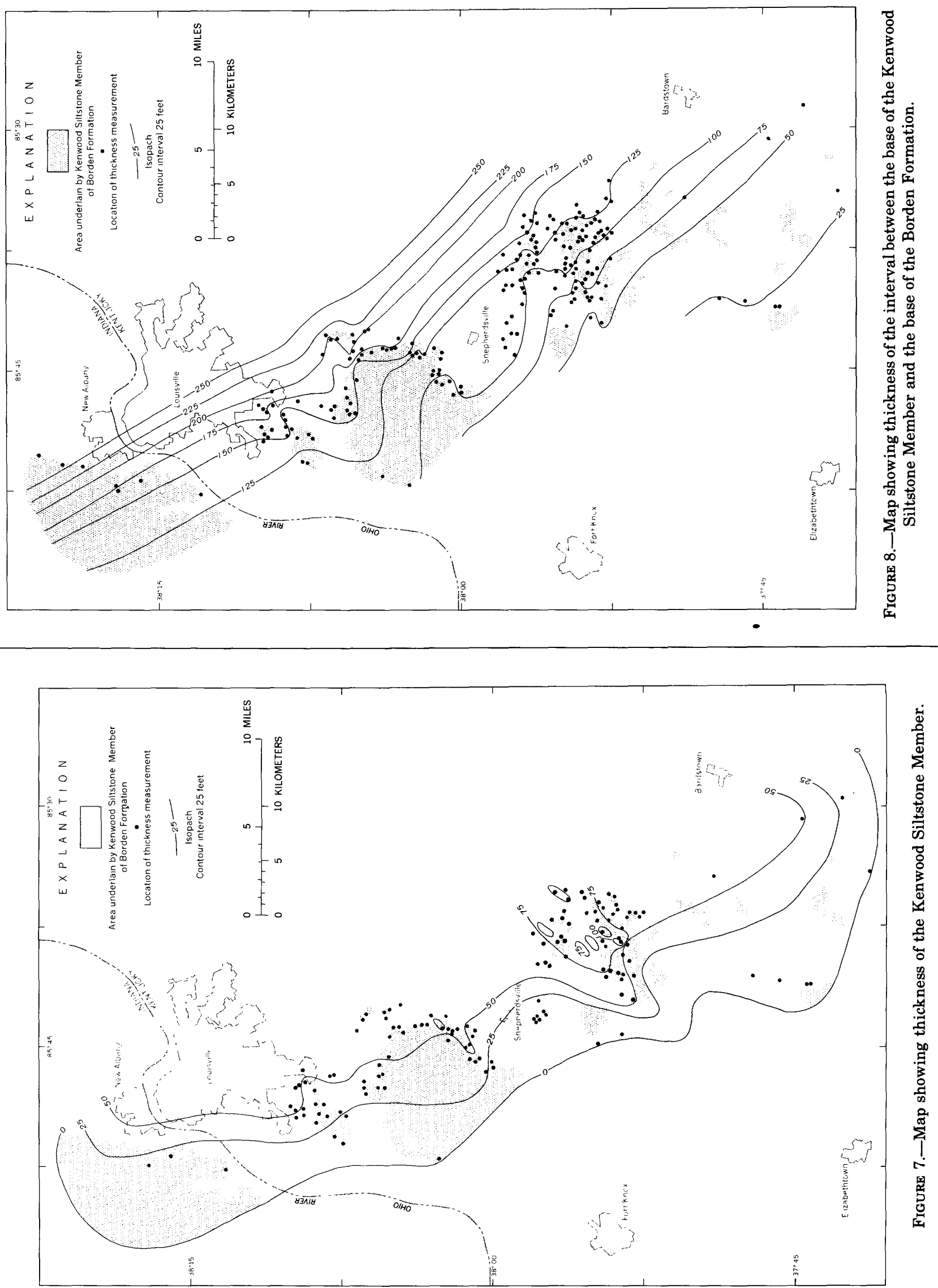

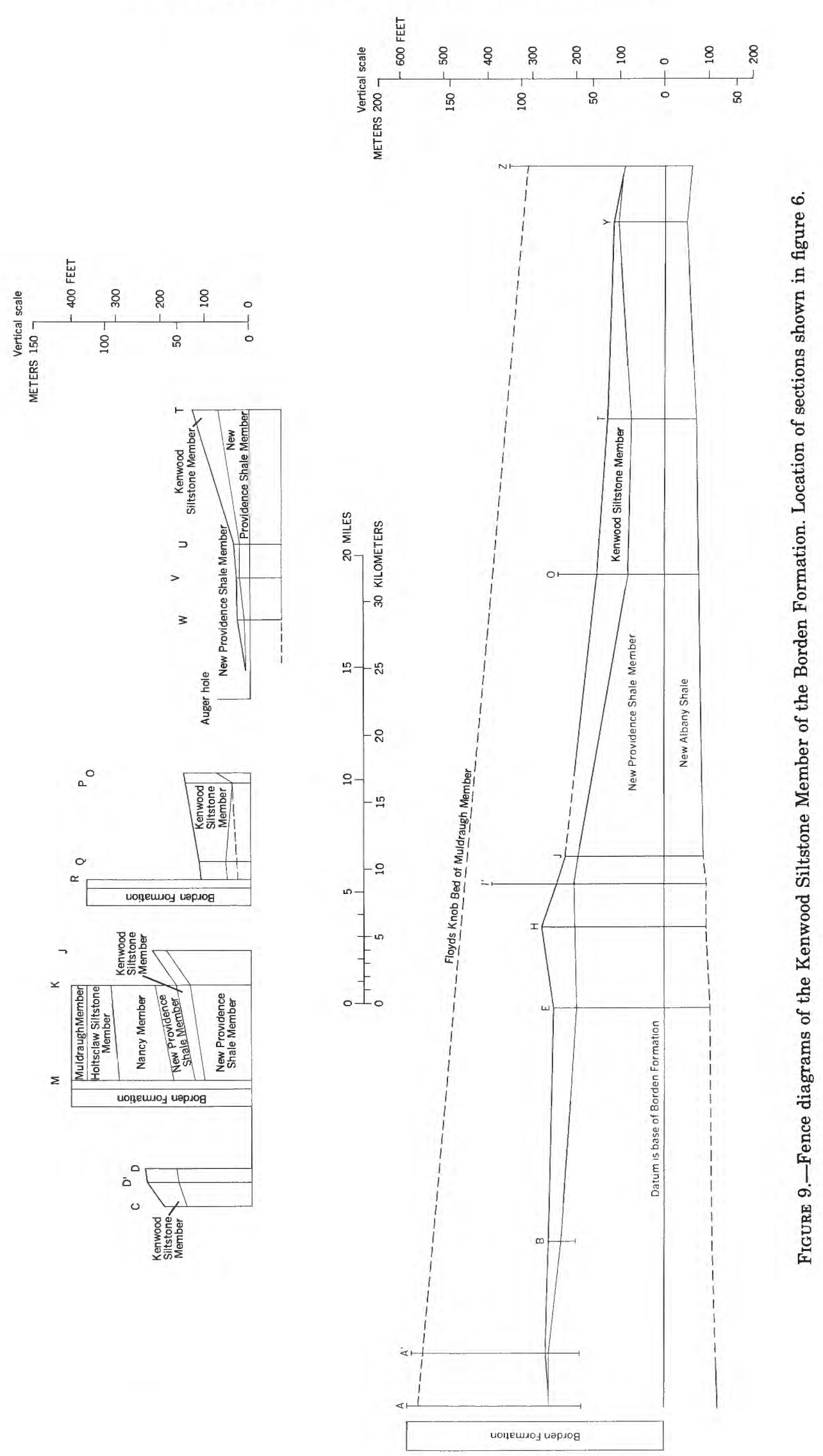


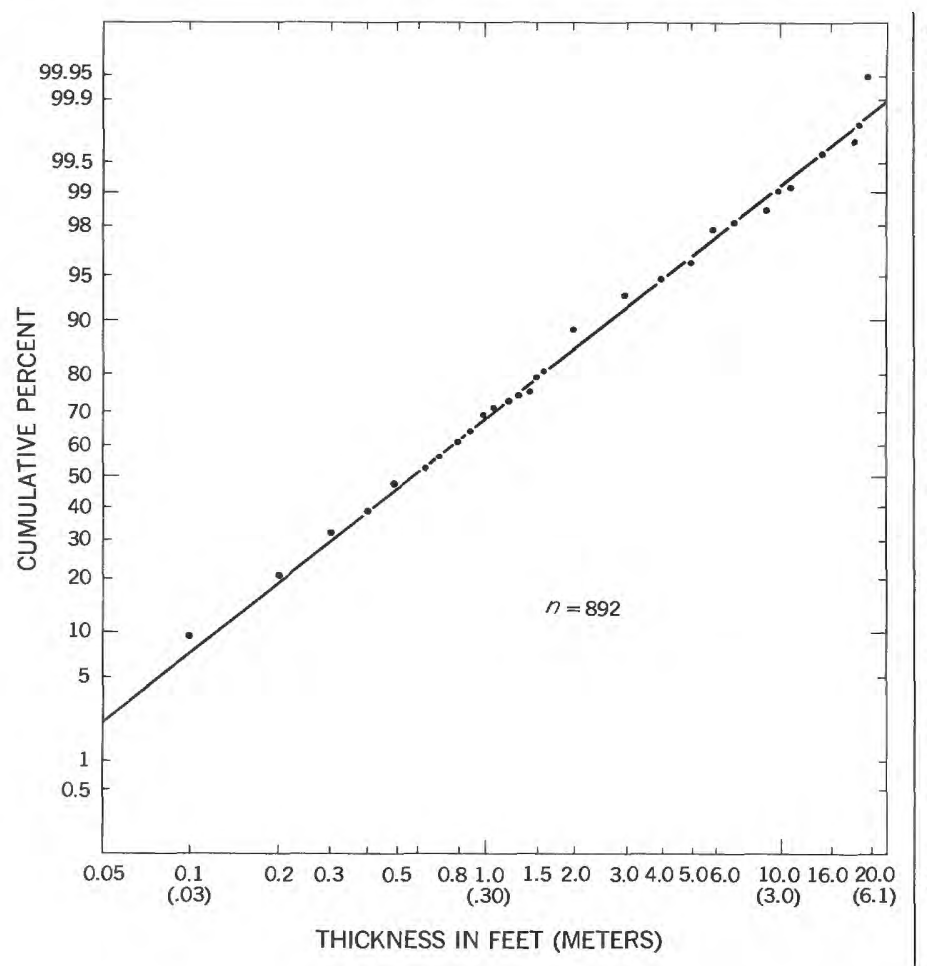

edge of outcrop about midway between Shepherdsville and Bardstown. Extending southward from this area is a narrow belt containing a high percentage of siltstone. Elsewhere the siltstone makes up only a small part of the member.

\section{PETROLOGY}

The Kenwood Siltstone Member of the Borden Formation was studied petrologically in samples from two main areas. One of these is the Kenwood type section on Kenwood Hill, Jefferson County, Ky. (loc. E, fig. 6); the other is to the south, near Shepherdsville, Bullitt County, Ky. The textural parameters and composition of these Kenwood samples are compared with siltstone samples from three other members of the Borden Formation (Holtsclaw Siltstone Member, Farmers Member, and "Rockcastle freestone" beds of the Wildie Member) and the Knifley Sandstone Member of the Fort Payne Formation.

FIGURE 10.-Cumulative curve showing thickness distribution of siltstone beds of the Kenwood (arithmetic probability paper with thickness on a logarithmic scale).

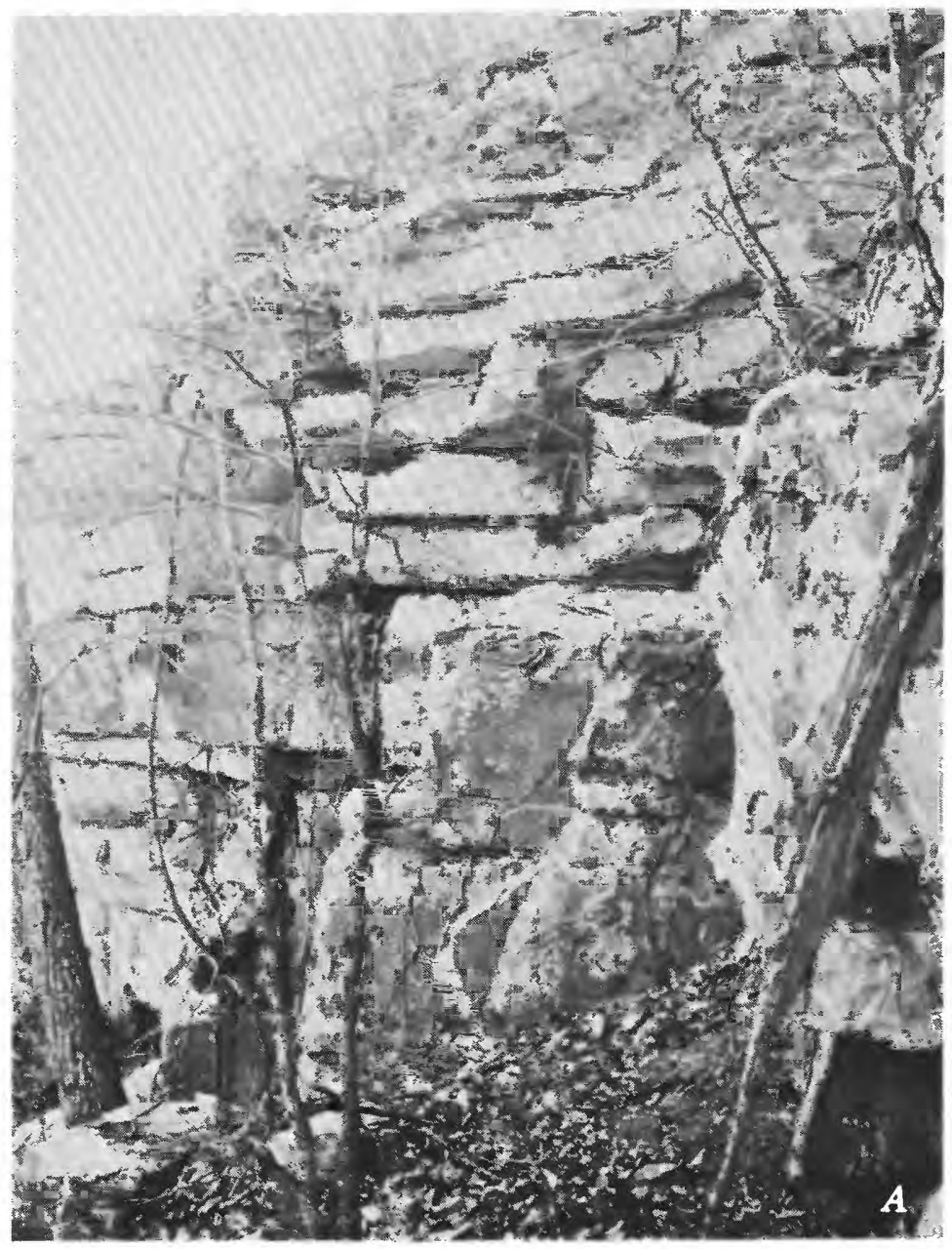




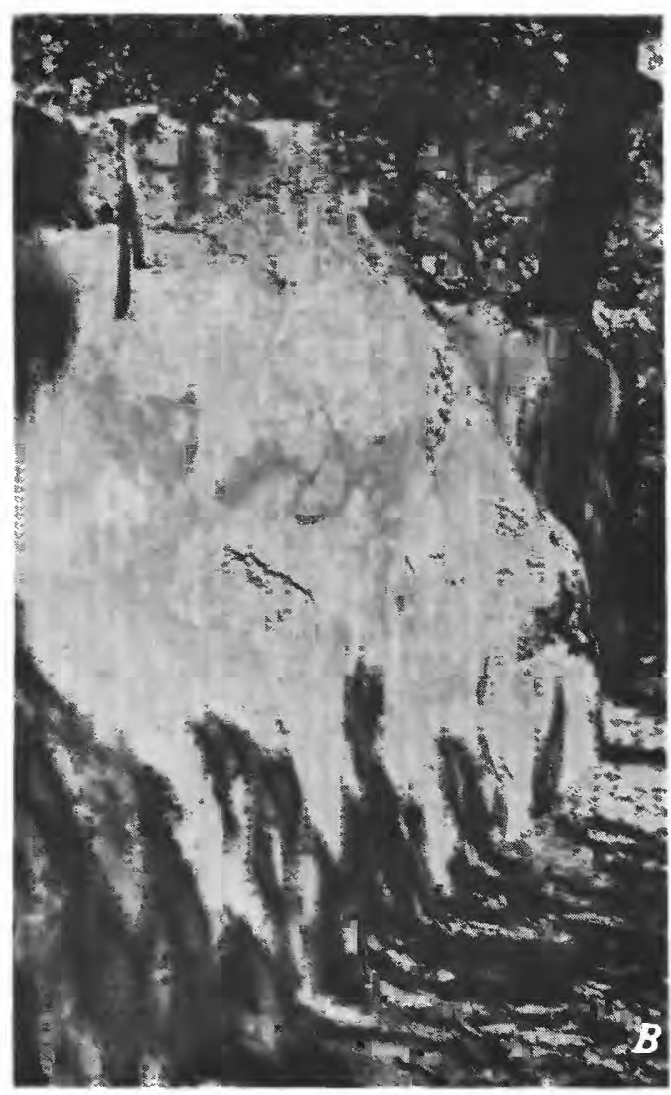

\section{COMPOSITION}

Both siltstone and shale of the Kenwood are made up of silt and clay. The distinction between the two lithologies is based on the dominance of silt or clay (fig. 15).

\section{SILTSTONE}

Composition of the siltstone of the Kenwood Siltstone Member was studied in 46 thin sections of samples from 15 beds. Most samples are from near the top and base of beds, and some are from within the thicker beds. Three hundred point counts per thin section were made of framework grains and matrix to determine mineral percentages. As a check, qualitative mineralogy was determined by X-ray diffraction.

The major framework constituents of the siltstone are quartz, feldspar, and rock fragments. They make up from about 49 to 80 percent and average about 68 percent of the rock. The matrix is chiefly sericitic illitic clay, limonite, and microcrystalline quartz. The matrix makes up from about 11 to 52 percent and averages about 28 percent. The matrix is obscured in unweathered samples by calcite or pyrite cement. Data for individual samples are shown in table 1 and summarized in figures 16 and 17.

Quartz constitutes 54-93 percent of the framework grains. Three types were identified: plain quartz (71 percent of the quartz grains), polycrystalline quartz (21 percent), and undulose quartz ( 8 percent). Diagenetic silica cement is suggested by overgrowths on some

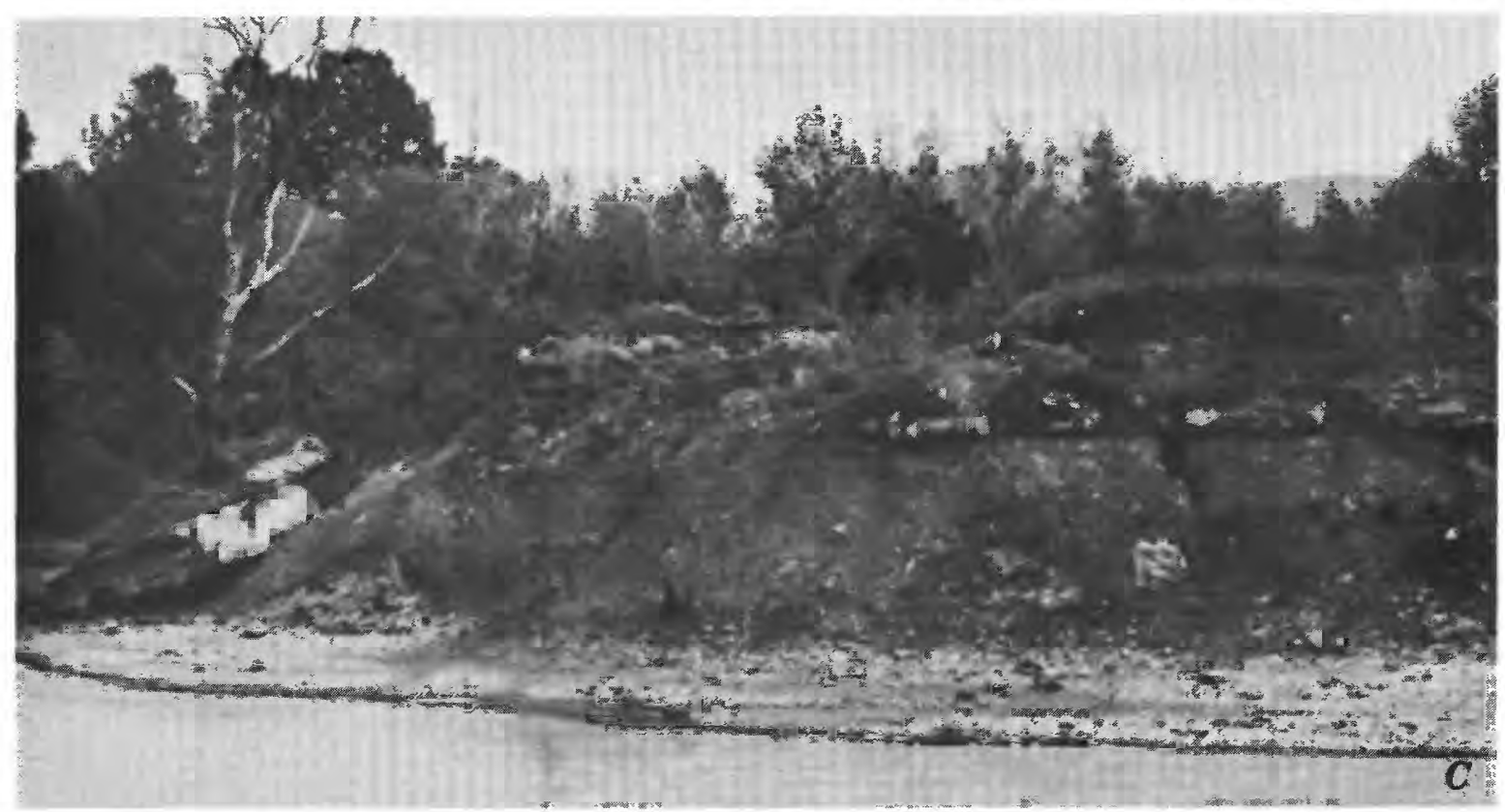

FIGURE 11.-Photographs showing thick beds in the Kenwood Siltstone Member. A, Channel fill, type III, Cane Hollow, loc. N, figure 6. B, Channel fill, type II, Buttonmold Knob, loc. J, figure 6. C, Channel fill, type II, Rolling Fork, loc. W, figure 6. Channel-fill types shown diagrammatically in figure 13. 

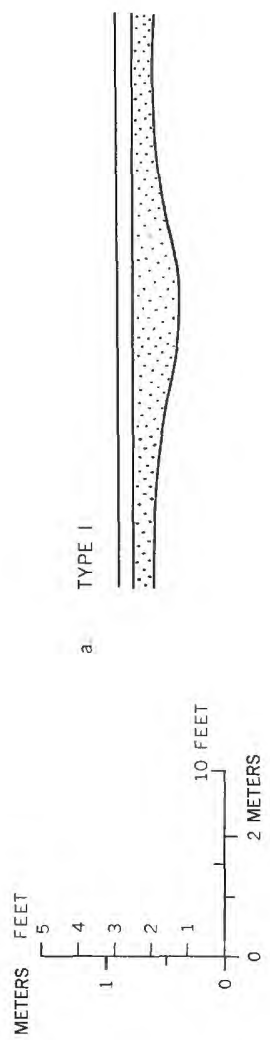
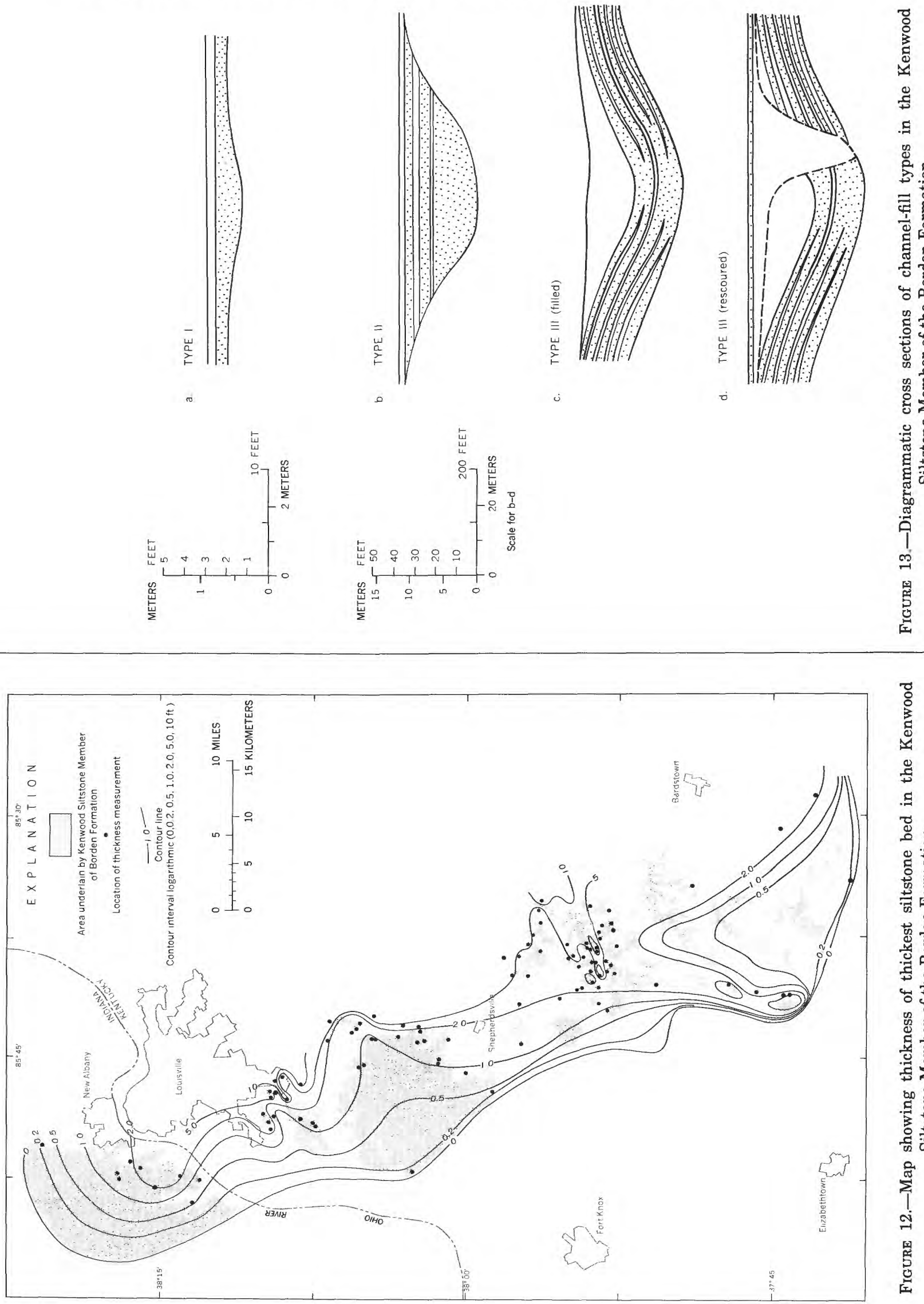
PETROLOGY
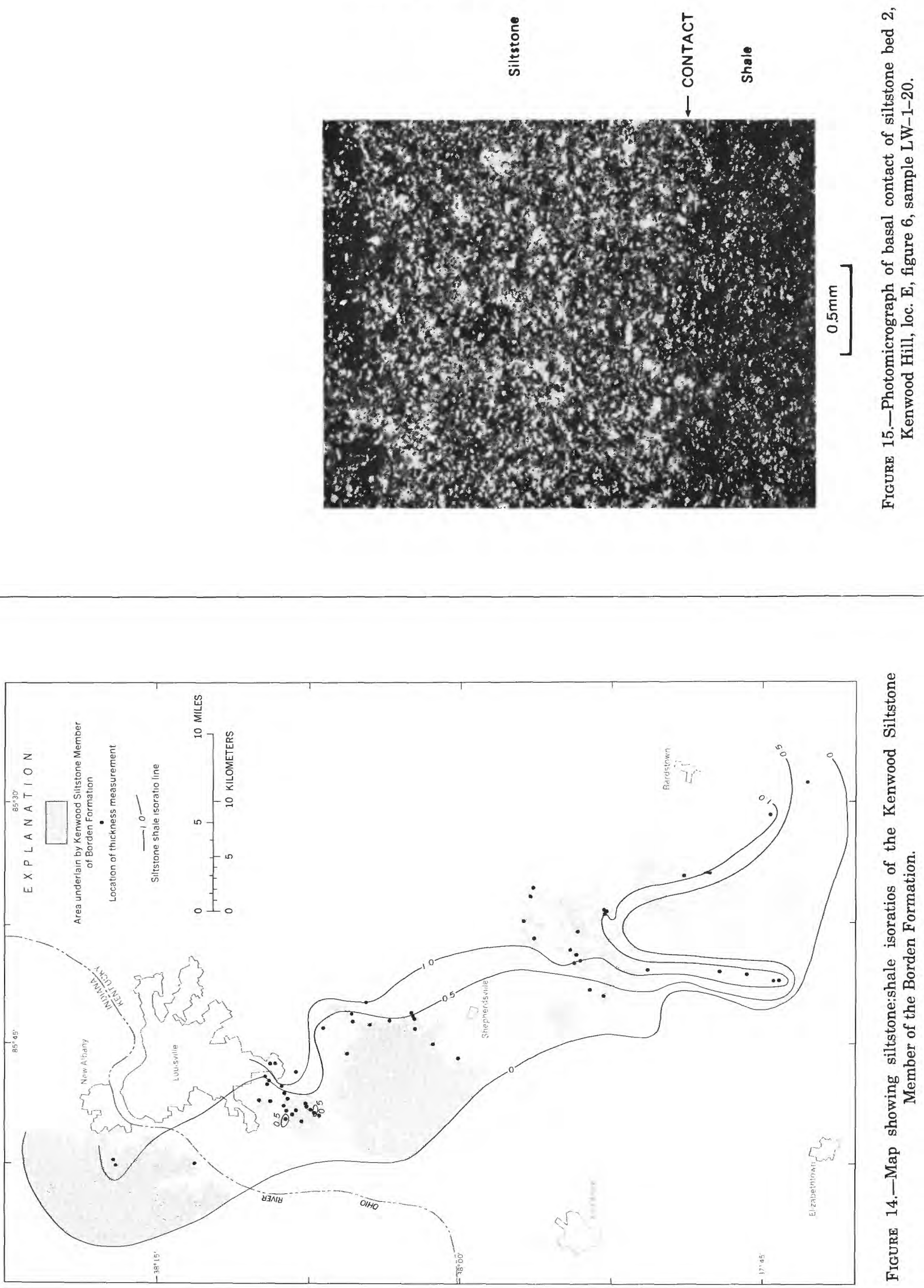

要 
PETROLOGY

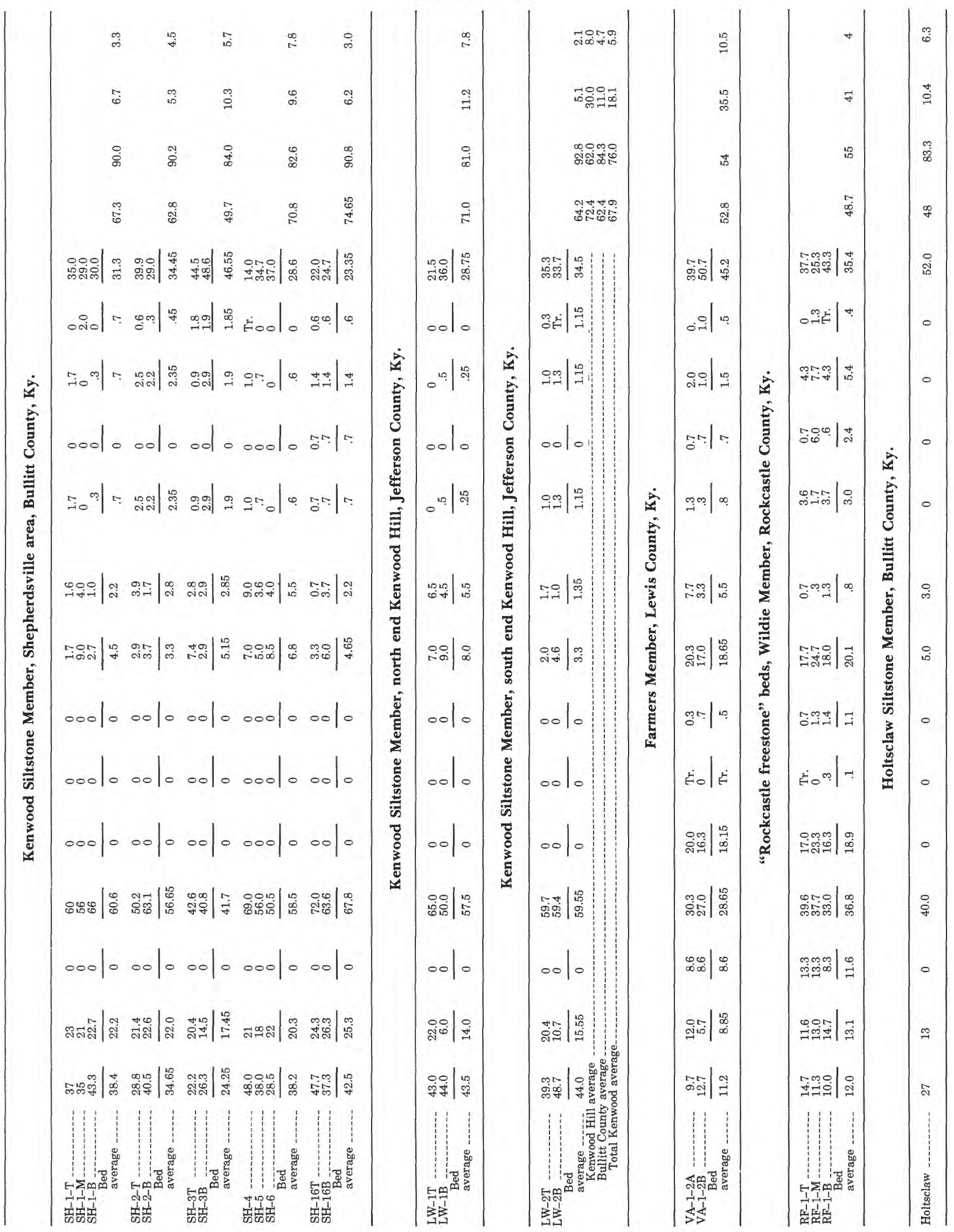



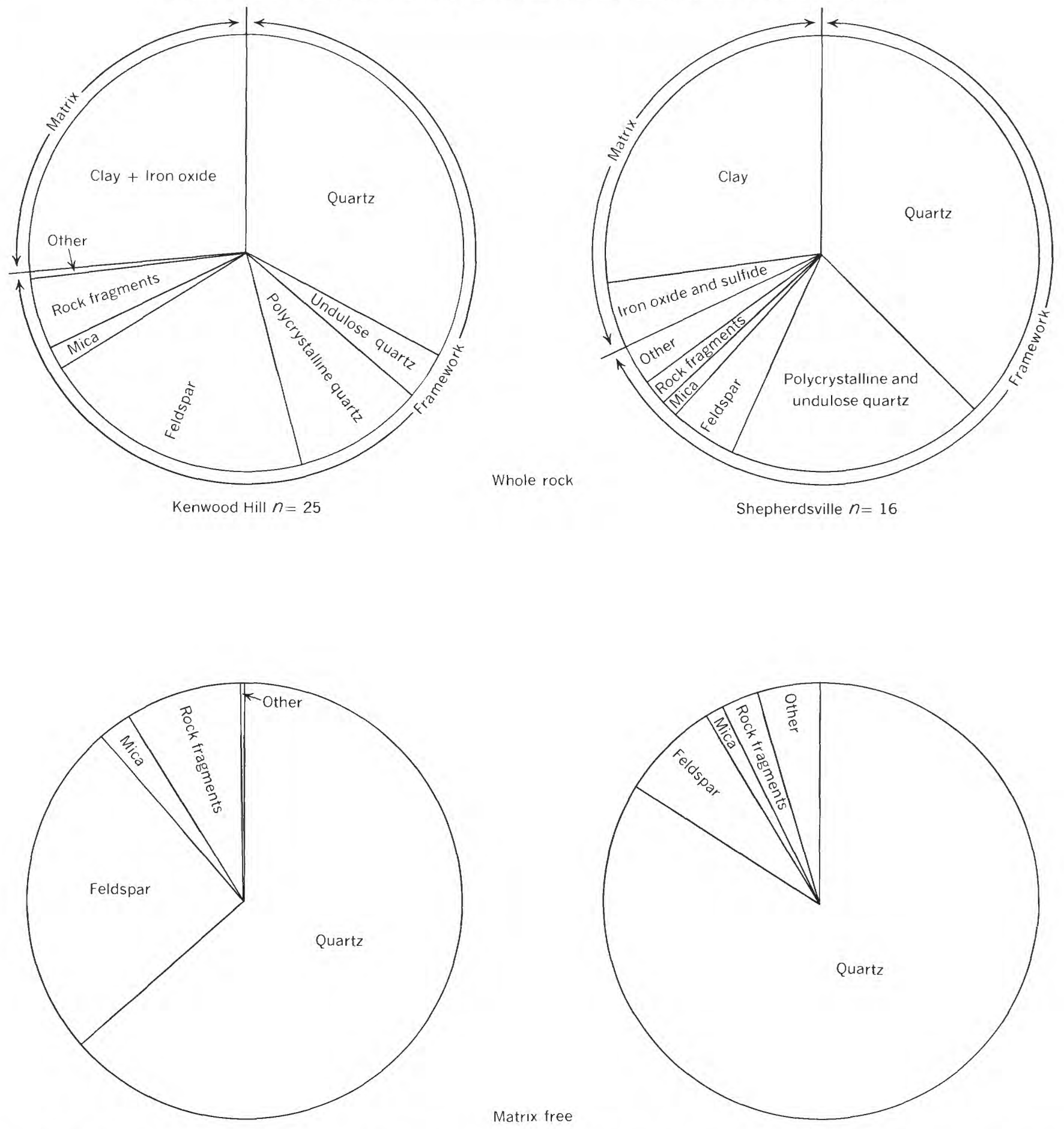

Figure 16.-Pie diagrams showing average modal composition of Kenwood Siltstone Member of the Borden Formation at two locations (table 1)

quartz grains in the form of indistinct rims and by clusters of grains which seem to radiate from centers cemented with microcrystalline quartz. Minor bubble trains, reddish tetragonal cyrstallites, and rutile(?) needles are found in some of the quartz grains.

Feldspar, second most abundant constituent, consti- tutes 5-36 percent of the framework grains. Potassium feldspar (95 percent of the feldspar grains), plagioclase (5 percent), and a trace of microcline were identified. Feldspar identification was based largely on cleavage, twinning, relief, and inclusions. Extinction angles measured on twinned plagioclase grains range from $5^{\circ}$ 


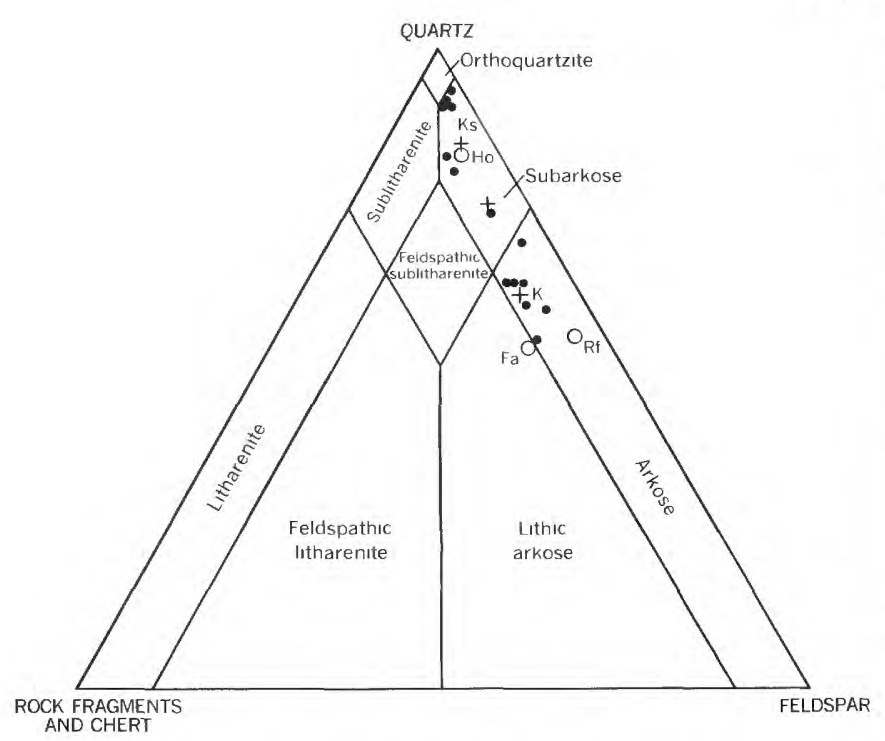

Figure 17.-Diagram showing composition of siltstone of Kenwood (solid dots) compared with that from Holtsclaw (Ho), Farmers $(\mathrm{Fa})$, and Wildie (Rf) Members of the Borden Formation (open circles). +, average Kenwood composition; + Ks, south area; $+\mathrm{K}$, Kenwood Hill. (Classification from Folk, 1968).

to $16^{\circ}$, indicating the presence of oligoclase, albite, and andesine. Many feldspar grains are elongate cleavage fragments having a length-to-width ratio of as much as 5:1. Some feldspar grains show overgrowths and solution embayments, and many show incipient sericitization (fig. 18).

Rock fragments are the third most abundant framework constituent, ranging from 6 to 10 percent. Identified fragments include mudstone, phyllitic quartzite, and chert, although some chert classed as rock fragments may be secondary.

Mica is conspicuous but not abundant in the Kenwood. The larger flakes range in abundance from a trace to nearly 3 percent. The smaller sericitic flakes are considered a part of the matrix. Of the large flakes, muscovite makes up all but about one-sixth, and chlorite, most of the remainder. Four mica varieties based on color (pink, colorless, brown, and green) were seen in some residue from samples analyzed for texture. Most mica flakes are subparallel to the bedding laminae; some flakes are bent by postdepositional compaction.

Other grains found in trace amounts are glauconite and the heavy minerals zircon, tourmaline, rutile, and

FigURE 18.-Photomicrographs of siltstone of the Kenwood. A, Silt grains in a pyrite matrix in cross-polarized light; Kenlite quarry, loc. L, figure 6; feldspar grain (f) shows overgrowth (o) accentuated by differential extinction (sample BR-1-1C). B, Clay-filled burrow in siltstone bed in plain light; Shepherdsville quadrangle, loc. $R$, figure 6 (sample SH-2T). C, Pyrite lamina in cross-polarized light; calcite matrix, loc. L, figure 6 (sample BR-1-1B).
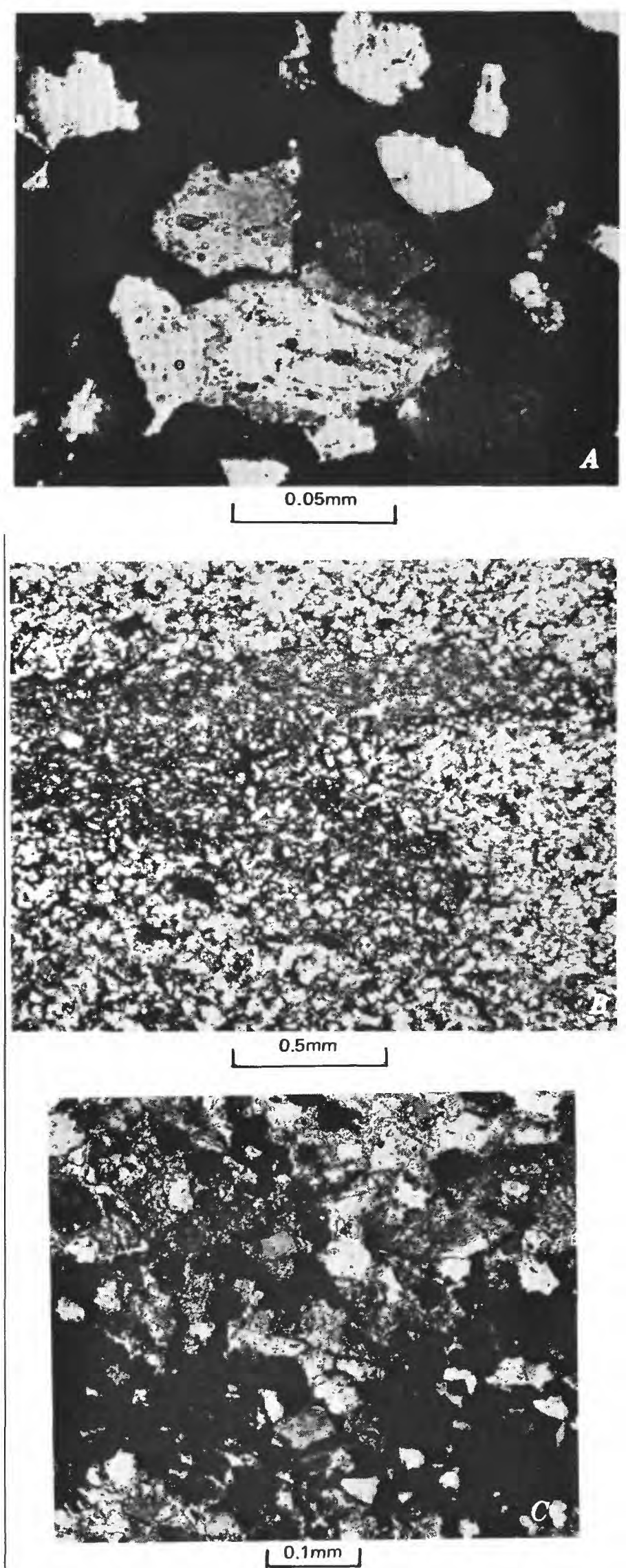
hornblende. The glauconite appears to be pelletal aggregates of possible fecal origin. Zircon is well rounded. Tourmaline grains are light blue-green and somewhat rounded at the ends.

Bulk X-ray mineralogy. - Qualitative and semiquantitative X-ray diffraction analyses of the siltstone in general corroborate the thin-section analyses; they indicate, however, that feldspar is less abundant than thin-section analyses suggest and is probably 15-25 percent of the total framework grains. (See fig. 19.)

Classification.-The siltstone of the Kenwood, according to modifications of a classification by Folk (1968, p. 124) and following recommendations of Picard (1971, p. 187), is clayey siltstone, illitesubarkose to illite-arkose. The siltstone of the Farmers is an illite-lithic arkose and that of the Wildie is the most arkosic of the samples studied. The sandstone of the Knifley Sandstone Member of the Fort Payne Formation is the least arkosic, an illite-sublitharenite (fig. 17).

Maturity.-Indices of maturity that depend on composition are generally related to abundance of quartz, feldspar, and rock fragments. The siltstone of the Kenwood is considered submature on the basis of its subarkosic to arkosic composition.

\section{CLAY MINERALOGY}

The clay fraction in five shale beds was examined by X-ray diffraction following suggestions of Warshaw and Roy (1961). The typical radiograph trace for the clay (fig. 20) shows that the main component is illite. Strong peaks at $14 \mathrm{~A}$ and $7 \mathrm{~A}$ indicate a chlorite plus vermiculite. I have seen similar patterns from the API standard Beaver Bend illite.

The approximate composition of the clay fraction of the interbedded shale of the Kenwood is 87 percent illite, 10 percent chlorite, and 3 percent vermiculite, as determined by the technique proposed by Schultz (1964) for semiquantitative clay-mineral estimation.

\section{TEXTURE}

The Kenwood, according to the scheme of nomenclature proposed by Folk (1954) is composed of mediumgrained sandy siltstone and siltstone, and silt shale to mud shale. (See fig. 21.)

\section{SILTSTONE}

Siltstone of the Kenwood has an average mean grain size $\left(M_{z}\right)$ of $5.36 \phi$, or $0.024 \mathrm{~mm}$, which is mediumgrained silt on the Wentworth scale. Mean grain size ranges from $4.37 \phi$ to $6.17 \phi(0.048-0.014 \mathrm{~mm})$. The siltstone is poorly to moderately sorted; the inclusive graphic standard deviation $\left(\sigma_{l}\right)$ ranges from $0.88 \phi$ to
$1.96 \phi$ and averages $1.28 \phi$. The frequency curves are strongly fine skewed (fig. 22); inclusive graphic skewness $\left(S k_{I}\right)$ ranges from +0.24 to +0.81 and averages +0.62 . The curves are also leptokurtic to extremely leptokurtic; graphic kurtosis $\left(K_{G}\right)$ values range from 1.35 to 5.50 and average 3.46. (See table 2.)

Coarsest grain.-The coarsest grain was determined from an average of the 10 coarsest grains in each siltstone thin section. The results for samples from Kenwood Hill are plotted with median diameter as determined from mechanical analysis on a vertical profile of the measured section (fig. 23). This plot shows a slight tendency to fine upward in both coarsest grain and median grain size in the sequence as a whole and in five of the six individual beds for which a comparison can be made. This upward fining in grain size, or grading in the Kenwood siltstone beds, is shown by all beds for which samples from both the base and top of the beds were analyzed texturally. The tendency to fine upwards in the bed results from a decrease or loss of the very fine sand fraction in the upper part of the beds (fig. 24).

Textural maturity. - The siltstone is texturally immature according to the maturity scheme applied to sandstone by Folk (1968, p. 108), in that the siltstone grains are subangular to angular and most samples contain more than 5 percent clay.

\section{DEPOSITIONAI ENVIRONMENT INDICATORS}

Statistical measures of textural data for the Kenwood show no significant pattern when plots are made of inclusive graphic skewness versus graphic kurtosis, graphic mean versus inclusive graphic skewness, and graphic mean versus inclusive graphic standard deviation.

Passega (1957) proposed the C-M diagram, which compares the grain size of the 99th percentile (or first percentile on cumulative grain size curves plotted herein) with the mean. Textural data for the siltstone of the Kenwood, plotted on the modified C-M diagram, fall near the fine end of the turbidite field and continue between that field and the field for pelagic suspension (fig. 25).

These plots and the positive skewness of the textural curves for the Kenwood show that both the siltstone and silt shale were deposited under conditions in which winnowing currents were rare or absent. Comparison with textural plots of Passega (1957) suggests that the deposits originated from pelagic suspension or turbidity currents.

\section{BEDDING STRUCTURES}

Bedding structures in the Kenwood Siltstone Member of the Borden Formation include bedding 
KENWOOD SILTSTONE MEMBER, BORDEN FORMATION, KENTUCKY AND INDIANA
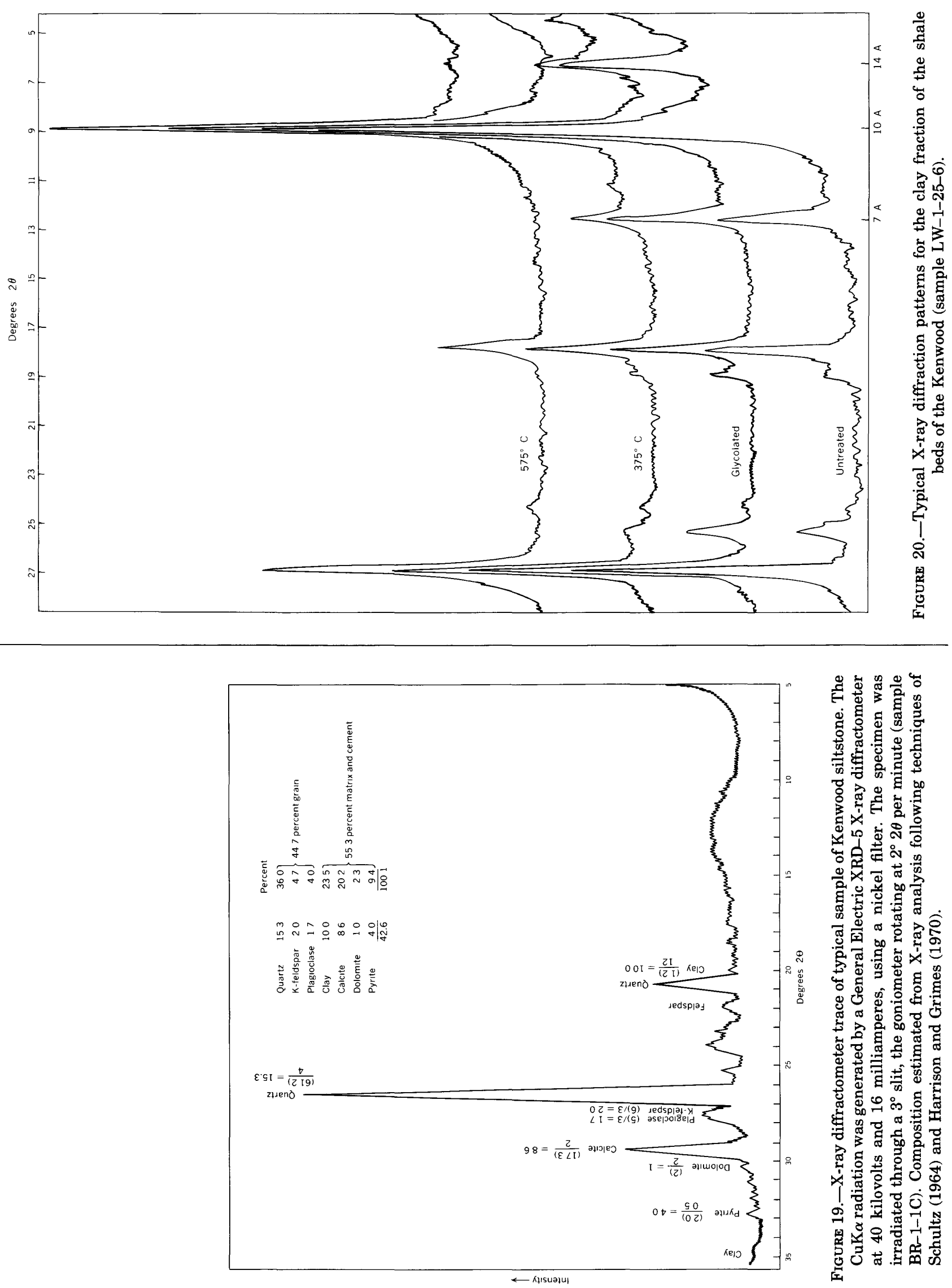


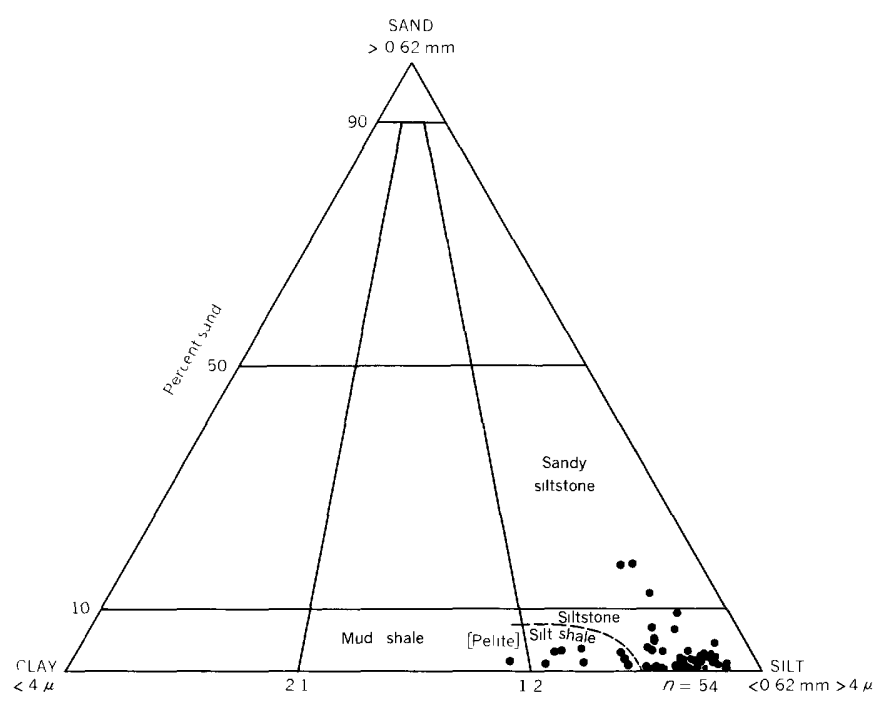

FIGURE 21.-Silt-sand-clay triangular plot of textural analyses of the Kenwood Siltstone Member of the Borden Formation. (Classification from Folk, 1968, p. 28.)

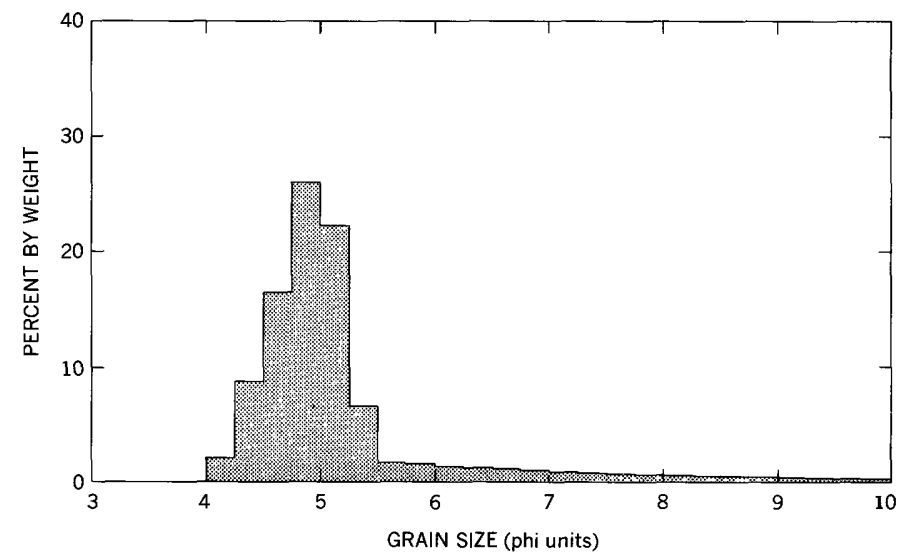

FIGURE 22.-Histogram of grain size in a typical siltstone sample of the Kenwood Siltstone Member of the Borden Formation.

laminae, ripples, and sole marks of current origin as well as trace fossils.

\section{INTERNAL SEDIMENTARY STRUCTURES}

Ubiquitous among the bedding structures in the siltstone beds of the Kenwood are planar horizontal bedding laminae. These laminae are subparallel to the base of the beds and in most beds appear to make up the only internal bedding structure of depositional origin. (See X-radiograph, fig 26.) Some of this lamination can be seen in thin section and appears to be due to microsorting of grain layers and interlayers of clayey laminae. Some of the lamination is enhanced in thin section by orientation of elongate grains and mica flakes subparallel to the base of the bed. Upon weather- ing, the beds show a tendency to part along these laminae.

Convolute laminae and associated flame structures are rare (fig. 27). Zones in which they occur are less than $0.5 \mathrm{ft}(15 \mathrm{~cm})$ thick and constitute less than a third of the thickness of the bed. The convolutions approach in appearance the inverted-mushroom shape of load casts or an arrested interchange between two layers of differing density, in which the upper layer was more dense than the lower. The origin has been attributed to refluidization during deposition of the bed (ten Haaf, 1956, p. 194).

Ripple laminae are sparse; most are a single "starved" layer one ripple amplitude in height, in which the ripple amplitude is less than $0.1 \mathrm{ft}(3 \mathrm{~cm})$ and the wavelength is $0.3-0.4 \mathrm{ft}(9-12 \mathrm{~cm})$. Most beds in which ripple laminae are visible also contain convolute laminae below the rippled layer. As shown in figure 28, there are three rippled layers, one below and one above a convoluted layer and a third as climbing ripples.

Bedding without laminae is sparse. Along the Lookout Tower Road section in Bernheim Forest (loc. O, fig. 6), the basal part of a siltstone bed is apparently unlaminated but is overlain by horizontal laminae (fig. 27B).

A form of grading in some of the beds (bed 4, loc. $\mathrm{E}$, fig. 6) is shown by a lag concentrate of ostracode (?) tests; other beds include clay clasts near their bases.

Sideritic concretions are common within the siltstone beds. The concretions occur as individual spherical zones of cement, grading to coalescing zones that impart a pseudolayering to the bed. Rarely do beds contain more than one layer of such concretionary zones; commonly, the zone is restricted to the middle of the bed (fig. 29). The zones are most prevalent in beds thicker than $1 \mathrm{ft}(30 \mathrm{~cm})$, and the zones appear to occupy about the same interval as does the rarely observed convolute bedding, implying a genetic relationship between the two. Weathering alters these layers to limonite in concentric Liesegang rings that further obscure the original bedding. Siderite also occurs in the shale beds.

More conspicuous because of their contrast with the enclosing sediments are continuous zones of siderite nodules in the New Providence Shale Member below the Kenwood. In the Lebanon Junction (Peterson, 1967) and Shepherdsville quadrangles (Kepferle, 1968a), the sideritic zones appear to be continuations of the siltstone beds of the Kenwood. The centering of a nodule on a thin siltstone bed, as shown in figure 29 , shows the transition of one type of occurrence to the other. Zones along which the siderite concretions are concentrated were probably slightly more porous than the adjacent sediment and were avenues for iron-rich 
TABLE 2.-Statistical parameters for textural analysis of the Kenwood Siltstone Member of the Borden Formation [Analysts: Helen Bataia R. F. Gantnier, and R. C. Kepferle, U.S. Geol. Survey]

Grain size in phi units at designated percentile on cumulative curves

\begin{tabular}{|c|c|c|c|c|c|c|c|c|c|c|c|c|}
\hline Sample no. & $C 2$ & 5 & 16 & 25 & $M_{d} 50$ & 75 & 84 & 95 & $M_{z^{\prime}}(\phi)$ & $S k_{I}$ & $\sigma_{I}(\phi)$ & $K_{G}$ \\
\hline \multicolumn{13}{|c|}{ Siltstone } \\
\hline 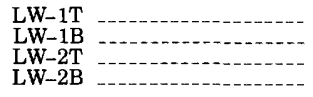 & $\begin{array}{l}3.85 \\
3.75 \\
3.70 \\
3.40\end{array}$ & $\begin{array}{l}4.20 \\
4.05 \\
4.10 \\
3.80\end{array}$ & $\begin{array}{l}4.50 \\
4.35 \\
4.40 \\
4.20\end{array}$ & $\begin{array}{l}4.65 \\
4.50 \\
4.60 \\
4.40\end{array}$ & $\begin{array}{l}4.95 \\
4.80 \\
4.95 \\
4.75\end{array}$ & $\begin{array}{l}5.25 \\
5.10 \\
5.95 \\
5.15\end{array}$ & $\begin{array}{l}5.55 \\
5.20 \\
7.40 \\
5.40\end{array}$ & $\begin{array}{l}10.30 \\
10.00 \\
10.20 \\
10.20\end{array}$ & $\begin{array}{l}5.00 \\
4.78 \\
5.58 \\
4.78\end{array}$ & $\begin{array}{r}+0.45 \\
+.34 \\
+.68 \\
+.39\end{array}$ & $\begin{array}{l}1.20 \\
1.11 \\
1.68 \\
1.27\end{array}$ & $\begin{array}{l}4.18 \\
4.07 \\
1.86 \\
3.50\end{array}$ \\
\hline 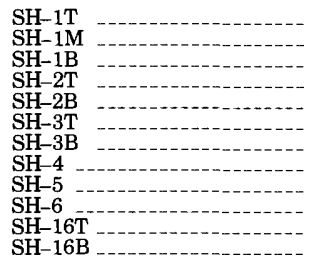 & $\begin{array}{l}3.40 \\
3.10 \\
2.85 \\
3.45 \\
3.30 \\
4.10 \\
3.85 \\
3.60 \\
3.75 \\
3.90 \\
2.70 \\
2.15\end{array}$ & $\begin{array}{l}3.95 \\
3.70 \\
3.50 \\
4.00 \\
3.90 \\
4.35 \\
4.15 \\
3.95 \\
4.05 \\
4.20 \\
3.20 \\
2.95\end{array}$ & $\begin{array}{l}4.35 \\
4.20 \\
4.10 \\
4.45 \\
4.35 \\
4.60 \\
4.45 \\
4.20 \\
4.35 \\
4.45 \\
3.85 \\
3.75\end{array}$ & $\begin{array}{l}4.90 \\
4.75 \\
4.65 \\
4.75 \\
4.65 \\
4.70 \\
4.60 \\
4.60 \\
4.65 \\
4.80 \\
4.20 \\
4.10\end{array}$ & $\begin{array}{l}5.20 \\
5.10 \\
4.95 \\
5.30 \\
5.20 \\
4.95 \\
4.90 \\
4.75 \\
4.85 \\
4.95 \\
5.05 \\
4.90\end{array}$ & $\begin{array}{l}6.00 \\
5.65 \\
5.80 \\
5.80 \\
5.75 \\
5.20 \\
5.20 \\
5.10 \\
5.15 \\
5.25 \\
5.85 \\
5.70\end{array}$ & $\begin{array}{l}7.60 \\
7.00 \\
7.00 \\
7.25 \\
7.25 \\
5.35 \\
5.35 \\
5.25 \\
5.90 \\
5.40 \\
6.80 \\
6.10\end{array}$ & $\begin{array}{r}10.35 \\
10.22 \\
9.45 \\
10.62 \\
10.35 \\
10.25 \\
10.25 \\
8.00 \\
8.55 \\
9.20 \\
10.30 \\
10.20\end{array}$ & $\begin{array}{l}5.72 \\
5.43 \\
5.35 \\
5.67 \\
5.60 \\
4.97 \\
4.90 \\
4.73 \\
4.37 \\
4.93 \\
5.23 \\
4.92\end{array}$ & $\begin{array}{l}+.46 \\
+.47 \\
+.55 \\
+.57 \\
+.51 \\
+.43 \\
+.38 \\
+.28 \\
+.50 \\
+.32 \\
+.33 \\
+.24\end{array}$ & $\begin{array}{r}1.78 \\
1.69 \\
1.62 \\
1.70 \\
1.70 \\
1.08 \\
1.14 \\
.88 \\
1.07 \\
1.00 \\
1.81 \\
1.89\end{array}$ & $\begin{array}{l}2.39 \\
2.96 \\
2.12 \\
2.58 \\
2.41 \\
4.83 \\
4.17 \\
3.34 \\
3.72 \\
4.54 \\
4.46 \\
4.96\end{array}$ \\
\hline LW-1-70 & 4.11 & 4.32 & 4.52 & 4.62 & 4.83 & 5.04 & 7.30 & 10.57 & 5.55 & +.807 & 1.641 & 5.08 \\
\hline $\begin{array}{l}\text { LW-1-62 } \\
\text { LW-1-61 } \\
\text { LW-1-60 }\end{array}$ & $\begin{array}{l}4.06 \\
3.96 \\
3.84\end{array}$ & $\begin{array}{l}4.37 \\
4.23 \\
4.19\end{array}$ & $\begin{array}{l}4.67 \\
4.50 \\
4.52\end{array}$ & $\begin{array}{l}4.81 \\
4.62 \\
4.68\end{array}$ & $\begin{array}{l}5.13 \\
4.89 \\
5.07\end{array}$ & $\begin{array}{l}7.00 \\
6.24 \\
7.11\end{array}$ & $\begin{array}{l}8.71 \\
7.57 \\
8.48\end{array}$ & $\begin{array}{l}10.65 \\
10.38 \\
10.47\end{array}$ & $\begin{array}{l}6.17 \\
5.65 \\
6.02\end{array}$ & $\begin{array}{l}+.765 \\
+.771 \\
+.726\end{array}$ & $\begin{array}{l}1.960 \\
1.697 \\
1.943\end{array}$ & $\begin{array}{l}1.17 \\
1.56 \\
1.03\end{array}$ \\
\hline $\begin{array}{l}\text { LW-1-52 } \\
\text { LW-1-51 } \\
\text { LW-1-50 }\end{array}$ & $\begin{array}{l}4.02 \\
3.97 \\
3.90\end{array}$ & $\begin{array}{l}4.28 \\
4.22 \\
4.12\end{array}$ & $\begin{array}{l}4.50 \\
4.45 \\
4.38\end{array}$ & $\begin{array}{l}4.62 \\
4.58 \\
4.52\end{array}$ & $\begin{array}{l}4.87 \\
4.82 \\
4.78\end{array}$ & $\begin{array}{l}5.55 \\
5.40 \\
5.50\end{array}$ & $\begin{array}{l}7.06 \\
6.80 \\
6.73\end{array}$ & $\begin{array}{r}10.00 \\
9.60 \\
9.50\end{array}$ & $\begin{array}{l}5.48 \\
5.36 \\
5.30\end{array}$ & $\begin{array}{l}+.753 \\
+.732 \\
+.707\end{array}$ & $\begin{array}{l}1.506 \\
1.407 \\
1.403\end{array}$ & $\begin{array}{l}2.53 \\
2.69 \\
2.25\end{array}$ \\
\hline $\begin{array}{l}\text { LW-1-43 } \\
\text { LW-1-42 } \\
\text { LW-1-41 } \\
\text { LW-1-40 }\end{array}$ & $\begin{array}{l}4.10 \\
3.88 \\
3.98 \\
3.87\end{array}$ & $\begin{array}{l}4.33 \\
4.18 \\
4.19 \\
4.15\end{array}$ & $\begin{array}{l}4.57 \\
4.44 \\
4.43 \\
4.40\end{array}$ & $\begin{array}{l}4.68 \\
4.58 \\
4.58 \\
4.52\end{array}$ & $\begin{array}{l}4.90 \\
4.87 \\
4.82 \\
4.78\end{array}$ & $\begin{array}{l}5.88 \\
5.93 \\
5.30 \\
5.03\end{array}$ & $\begin{array}{l}6.90 \\
7.46 \\
6.95 \\
6.02\end{array}$ & $\begin{array}{r}10.18 \\
10.32 \\
10.10 \\
9.56\end{array}$ & $\begin{array}{l}5.49 \\
5.58 \\
5.40 \\
5.07\end{array}$ & $\begin{array}{l}+.760 \\
+.731 \\
+.739 \\
+.650\end{array}$ & $\begin{array}{l}1.468 \\
1.711 \\
1.525 \\
1.225\end{array}$ & $\begin{array}{l}2.01 \\
1.89 \\
3.38 \\
4.36\end{array}$ \\
\hline $\begin{array}{l}\text { LW-1-36 } \\
\text { LW-1-35 } \\
\text { LW-1-34 } \\
\text { LW-1-33 } \\
\text { LW-1-32 } \\
\text { LW-1-31 } \\
\text { LW-1-30 }\end{array}$ & $\begin{array}{l}4.12 \\
4.15 \\
4.07 \\
4.11 \\
4.05 \\
4.03 \\
4.03\end{array}$ & $\begin{array}{l}4.32 \\
4.36 \\
4.30 \\
4.33 \\
4.28 \\
4.28 \\
4.27\end{array}$ & $\begin{array}{l}4.53 \\
4.57 \\
4.51 \\
4.55 \\
4.51 \\
4.50 \\
4.51\end{array}$ & $\begin{array}{l}4.62 \\
4.68 \\
4.62 \\
4.66 \\
4.62 \\
4.62 \\
4.62\end{array}$ & $\begin{array}{l}4.83 \\
4.88 \\
4.83 \\
4.88 \\
4.84 \\
4.86 \\
4.86\end{array}$ & $\begin{array}{l}5.08 \\
5.43 \\
5.42 \\
5.62 \\
5.68 \\
5.59 \\
5.52\end{array}$ & $\begin{array}{l}6.82 \\
7.10 \\
7.05 \\
7.10 \\
7.19 \\
6.75 \\
6.90\end{array}$ & $\begin{array}{r}9.96 \\
10.16 \\
10.10 \\
10.00 \\
10.15 \\
10.05 \\
10.02\end{array}$ & $\begin{array}{l}5.39 \\
5.52 \\
5.46 \\
5.51 \\
5.51 \\
5.37 \\
5.42\end{array}$ & $\begin{array}{l}+.777 \\
+.788 \\
+.781 \\
+.789 \\
+.782 \\
+.736 \\
+.751\end{array}$ & $\begin{array}{l}1.430 \\
1.512 \\
1.515 \\
1.471 \\
1.582 \\
1.427 \\
1.460\end{array}$ & $\begin{array}{l}5.03 \\
3.17 \\
2.97 \\
2.42 \\
2.31 \\
2.42 \\
2.63\end{array}$ \\
\hline $\begin{array}{l}\text { LW-1-23 }-1- \\
\text { LW-1-21 } \\
\text { LW-1-20 }\end{array}$ & $\begin{array}{l}4.23 \\
4.16 \\
4.22\end{array}$ & $\begin{array}{l}4.50 \\
4.43 \\
4.46\end{array}$ & $\begin{array}{l}4.74 \\
4.68 \\
4.68\end{array}$ & $\begin{array}{l}4.87 \\
4.82 \\
4.80\end{array}$ & $\begin{array}{l}5.14 \\
5.08 \\
5.04\end{array}$ & $\begin{array}{l}6.73 \\
6.51 \\
6.56\end{array}$ & $\begin{array}{l}8.15 \\
7.68 \\
7.85\end{array}$ & $\begin{array}{l}10.50 \\
10.40 \\
10.38\end{array}$ & $\begin{array}{l}6.01 \\
5.81 \\
5.86\end{array}$ & $\begin{array}{l}+.774 \\
+.760 \\
+.788\end{array}$ & $\begin{array}{l}1.762 \\
1.653 \\
1.68\end{array}$ & $\begin{array}{l}1.34 \\
1.45 \\
1.38\end{array}$ \\
\hline 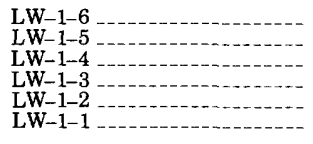 & $\begin{array}{l}4.18 \\
4.05 \\
4.08 \\
4.00 \\
3.95 \\
3.82\end{array}$ & $\begin{array}{l}4.40 \\
4.28 \\
4.30 \\
4.22 \\
4.19 \\
4.12\end{array}$ & $\begin{array}{l}4.62 \\
4.47 \\
4.50 \\
4.43 \\
4.41 \\
4.35\end{array}$ & $\begin{array}{l}4.73 \\
4.58 \\
4.60 \\
4.54 \\
4.51 \\
4.48\end{array}$ & $\begin{array}{l}4.95 \\
4.80 \\
4.80 \\
4.75 \\
4.73 \\
4.73\end{array}$ & $\begin{array}{l}6.40 \\
5.02 \\
5.20 \\
5.00 \\
4.95 \\
4.98\end{array}$ & $\begin{array}{l}7.88 \\
6.45 \\
7.00 \\
6.00 \\
5.75 \\
5.57\end{array}$ & $\begin{array}{r}10.46 \\
10.18 \\
10.25 \\
8.40 \\
8.10 \\
8.42\end{array}$ & $\begin{array}{l}5.82 \\
5.24 \\
5.43 \\
5.06 \\
4.96 \\
4.88\end{array}$ & $\begin{array}{l}+.808 \\
+.745 \\
+.790 \\
+.720 \\
+.697 \\
+.550\end{array}$ & $\begin{array}{r}1.734 \\
1.390 \\
1.528 \\
1.025 \\
.925 \\
.955\end{array}$ & $\begin{array}{l}1.49 \\
5.50 \\
4.07 \\
3.73 \\
3.64 \\
3.51\end{array}$ \\
\hline \multicolumn{13}{|c|}{ Shale } \\
\hline LW-1-54 & 3.60 & 4.40 & 5.20 & 5.62 & 6.40 & 8.50 & 10.00 & 10.95 & 7.20 & +0.444 & 1.113 & .932 \\
\hline LW-1-44 - & 4.10 & 4.91 & 5.70 & 6.09 & 6.90 & 9.00 & 10.10 & 11.04 & 7.57 & +.403 & 2.028 & .865 \\
\hline LW-1-37 - & 3.45 & 4.38 & 5.32 & 5.75 & 6.74 & 8.48 & 9.78 & 10.90 & 7.28 & +.432 & 2.104 & .945 \\
\hline $\begin{array}{l}\text { LW-1-10 } \\
\text { LW-1-9 } \\
\text { LW-1-7 }\end{array}$ & $\begin{array}{l}3.80 \\
3.86 \\
3.92\end{array}$ & $\begin{array}{l}4.48 \\
4.65 \\
4.68\end{array}$ & $\begin{array}{l}5.14 \\
5.45 \\
5.68\end{array}$ & $\begin{array}{l}5.42 \\
5.85 \\
6.15\end{array}$ & $\begin{array}{l}6.10 \\
6.68 \\
7.18\end{array}$ & $\begin{array}{l}8.15 \\
8.85 \\
9.10\end{array}$ & $\begin{array}{r}9.55 \\
10.10 \\
10.05\end{array}$ & $\begin{array}{l}10.88 \\
11.05 \\
11.00\end{array}$ & $\begin{array}{l}6.26 \\
7.41 \\
7.68\end{array}$ & $\begin{array}{l}+.529 \\
+.419 \\
+.270\end{array}$ & $\begin{array}{l}2.072 \\
2.133 \\
2.05\end{array}$ & $\begin{array}{l}.963 \\
.875 \\
.878\end{array}$ \\
\hline
\end{tabular}

fluids during formation of the concretions.

Locally, a zone as much as $0.4 \mathrm{ft}(12 \mathrm{~cm})$ thick is in the shale immediately beneath a siltstone bed. The zone is similar to zones called the "pre-phase" by Meischner (1964, p. 159), who ascribed their origin in limestone turbidites to currents in advance of the main density current. These currents are capable of moving bottom material for a short distance and redepositing it before the main current passes and without being incorporated into or mixed with material contained in the main current.

Reverse grading, indicated by an upward increase in grain size in the upper half of the bed, was seen in one bed on Kenwood Hill (loc. E, fig. 6). Similar reverse grading has been reported from turbidites by Beall (1970, p. 490).

With the exception of reverse grading, "pre-phase" deposits, and siderite associated with the zone of convolute bedding, the internal sequence of structures in siltstone beds of the Kenwood is similar to that attributed to turbidites by Bouma (1962, fig. 8). The internal sequence that Bouma labelled $T_{a}$ through $T_{e}$ fits an experimentally produced sequence of structures made by deposition from a steadily decreasing flow regime (Simons and others, 1965, fig. 21), where the basal part of the beds is massive and graded $\left(\mathrm{T}_{\mathrm{a}}\right)$, overlain by planar horizontal laminae $\left(\mathrm{T}_{\mathrm{b}}\right)$, in turn overlain by convolute or rippled laminae $\left(T_{c}\right)$, succeeded by planar 


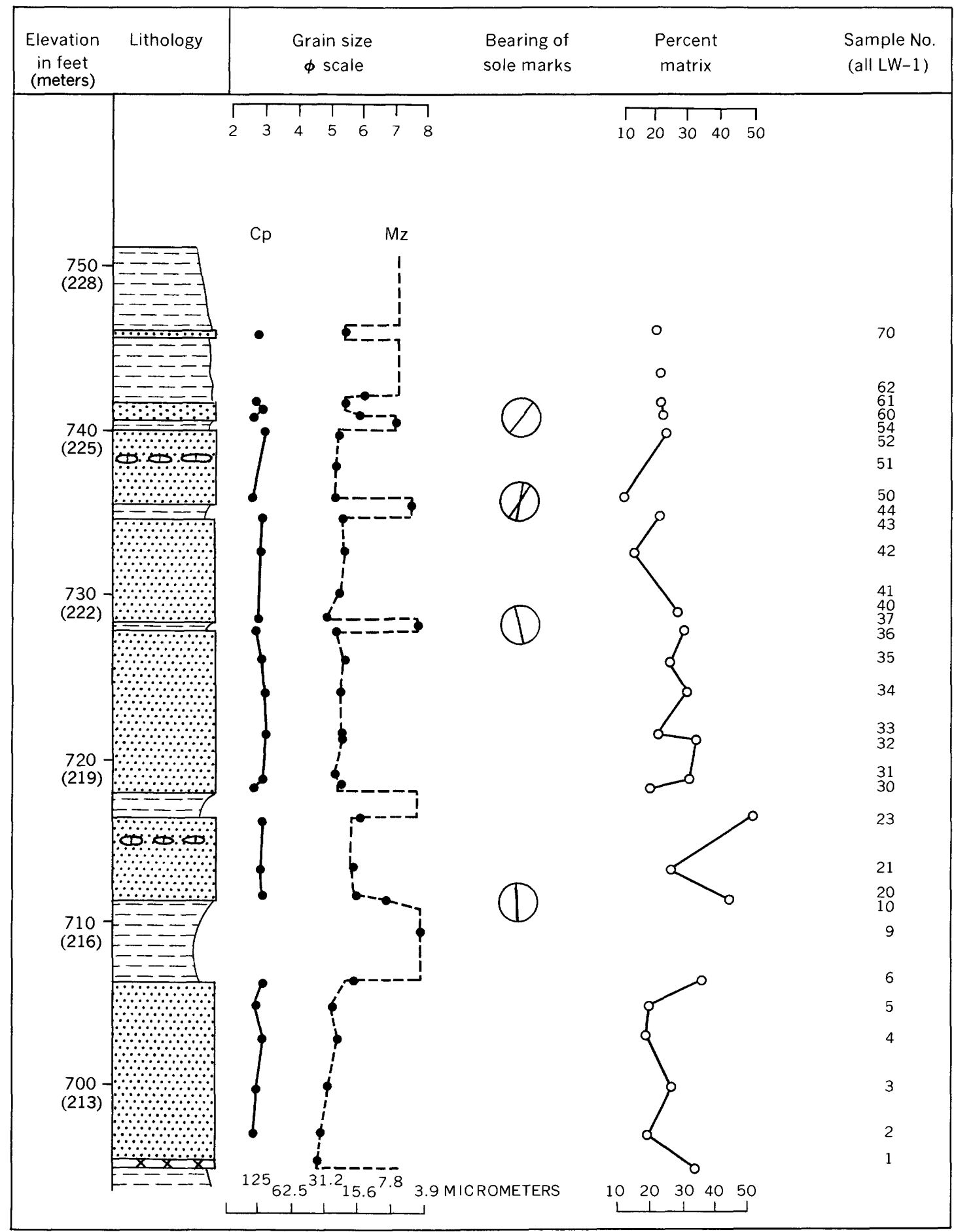

Figure 23.-Columnar section of exposure of Kenwood Siltstone Member at type locality (loc. E, fig. 6), showing vertical variation in coarsest grain estimated from thin section $\left(C_{p}\right)$, graphic mean grain size $\left(M_{z}\right)$, and sole mark lineation.

laminae $\left(\mathrm{T}_{\mathrm{d}}\right)$, and finally grading into a pelitic interval $\left(\mathrm{T}_{\mathrm{e}}\right)$. (See diagram correlating the flow regime and structures in an ideal turbidite, fig. 30.)

Siltstone beds of the Kenwood that show most or all of this sequence were noted in two localities: along the Firetower Hill section in Bernheim Forest (loc. O, fig. 6) and along Pleiss Hollow section (loc. B, fig. 6; fig. 28), west of New Albany, Ind. 


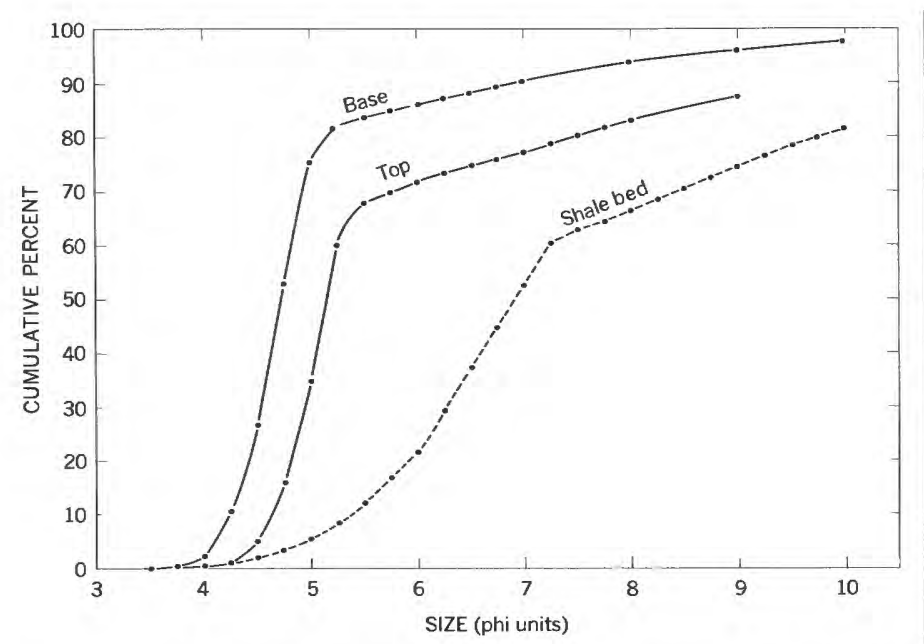

Figure 24.-Cumulative grain-size curves for samples from base (LW-1-1) and top (LW-1-23) of separate siltstone beds and of a silt shale bed (LW-1-44) in the Kenwood Siltstone Member.

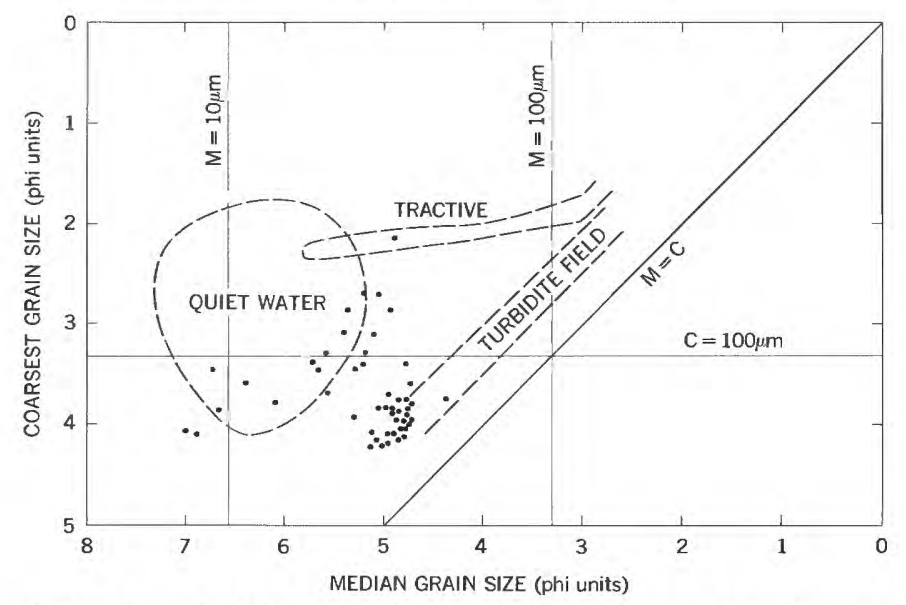

FIGURE 25.-C-M diagram showing grain-size image of the Kenwood (classification from Passega, 1957).

\section{EXTERNAL SEDIMENTARY STRUCTURES}

On some siltstone beds, the upper surface appears to be rippled; low-amplitude compound or cuspate ripples are common. Internally, most of the ripples show dipping lamination from which a current direction can be determined. Because for the most part the upper surface of the siltstone beds appears gradational with the overlying pelitic interval, external current-produced structures on the upper surfaces of beds are sparse.

The basal surface of siltstone beds in the Kenwood is abrupt and planar, with the exception of sole marks. The sole marks include casts of various impressions on the clay-rich slightly firm substrate of the siltstone beds. In order of abundance these casts include marks made by tools and currents and trace fossils. The most abundant tool marks are grooves, brush casts, prod, bounce, and roll marks. Less common among the sub- stratal marks are current crescents, flute casts, ruffled-groove marks described by Dzulynski and Simpson (1966, p. 201), and furrow-flute casts. (See fig. 31.)

Most of these structures are indicative of moderate cohesiveness in the underlying shale at the time the siltstone beds were deposited. This cohesiveness is well illustrated in the diagram of Hjulström (1939, fig. 1), which indicates that clays are cohesive to the extent that a higher velocity current is required for erosion to take place than that required to transport silt.

Many of the substratal features are current controlled. Some give an orientation, others, a vector sense to the paleocurrents that influenced their formation. A few beds, notably the basal bed in the Kenwood, show complete lack of sole marks; their contact with the underlying shale is planar and smooth.

\section{STRUCTURES OF ORGANIC ORIGIN}

A variety of trace fossils appears on the upper and lower surfaces of the siltstone beds, within the beds, and in the shale between the siltstone beds. Most earlier workers in the Borden have noted "curly" worm marks, now assigned to Scalarituba (Conkin and Conkin, 1968) and fucoids such as Taonurus, now commonly referred to as Zoophycos.

Trace fossils commonly noted in the Kenwood Siltstone Member of the Borden Formation include Scalarituba missouriensis Weller 1899, Cosmorhaphe?, Zoophycos Massalango 1853, Chondrites Sternberg 1833, Nereites Maclay 1839, Lophoctenium, Teichichnus, Paleophycos? Hall, and Planolites. In addition, several types of burrows were found for which no identification could be made from the available literature (mainly Häntzschel, 1962). These include vertical borings, most of which are fairly straight and nonbranching and have slightly irregular walls within which a clay filling commonly weathers out to form a simple Skolithus-like hole; the clay filling locally contains a siltstone plug that is crescent shaped in cross section. Common straight trails on the upper surface of the siltstone beds are tentatively attributed to orthoconic cephalopods. Representative photographs are included in figures 32 through 35 . The ichnocoenosis of the Kenwood is shown in the diagrams (figs. 36, 37) which relate the trace fossils to position within the siltstone beds of the Kenwood and to the Borden delta front.

The distribution density of trace fossils in the siltstone beds of the Kenwood is compatible with the turbidite origin suggested by the internal sequence of structures in the siltstone beds. The lack of borings and burrows near the base of the beds and the abundance of burrows near the top can be explained by rapid 

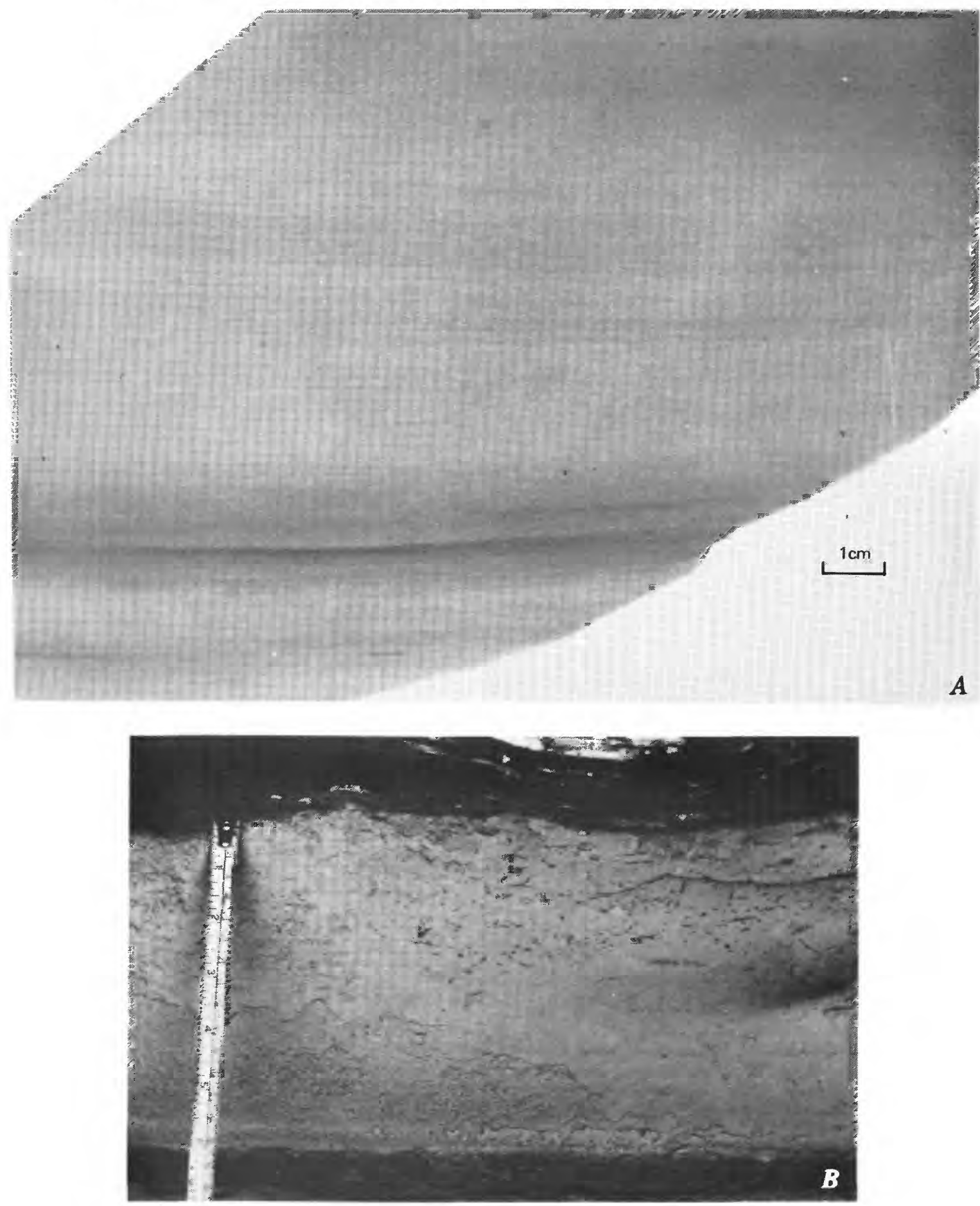

Figure 26.-Photographs showing planar lamination in siltstone of the Kenwood. $A$, X-radiograph of thin slab, loc. E, figure 6, sample LW-1-20. B, Bed beneath overhang along Crooked Creek, loc. P-Q, figure 6.

sedimentation of the siltstone relative to the shale. Such rapid sedimentation could have effectively buried the extant bottom fauna, some of which could have survived by escaping upward through the silt layers.
Reestablishment of the fauna after silt deposition was generally slow and was dependent on a relatively long interval of time under conditions of slow pelagic sedimentation. This is indicated by the lack of trace 

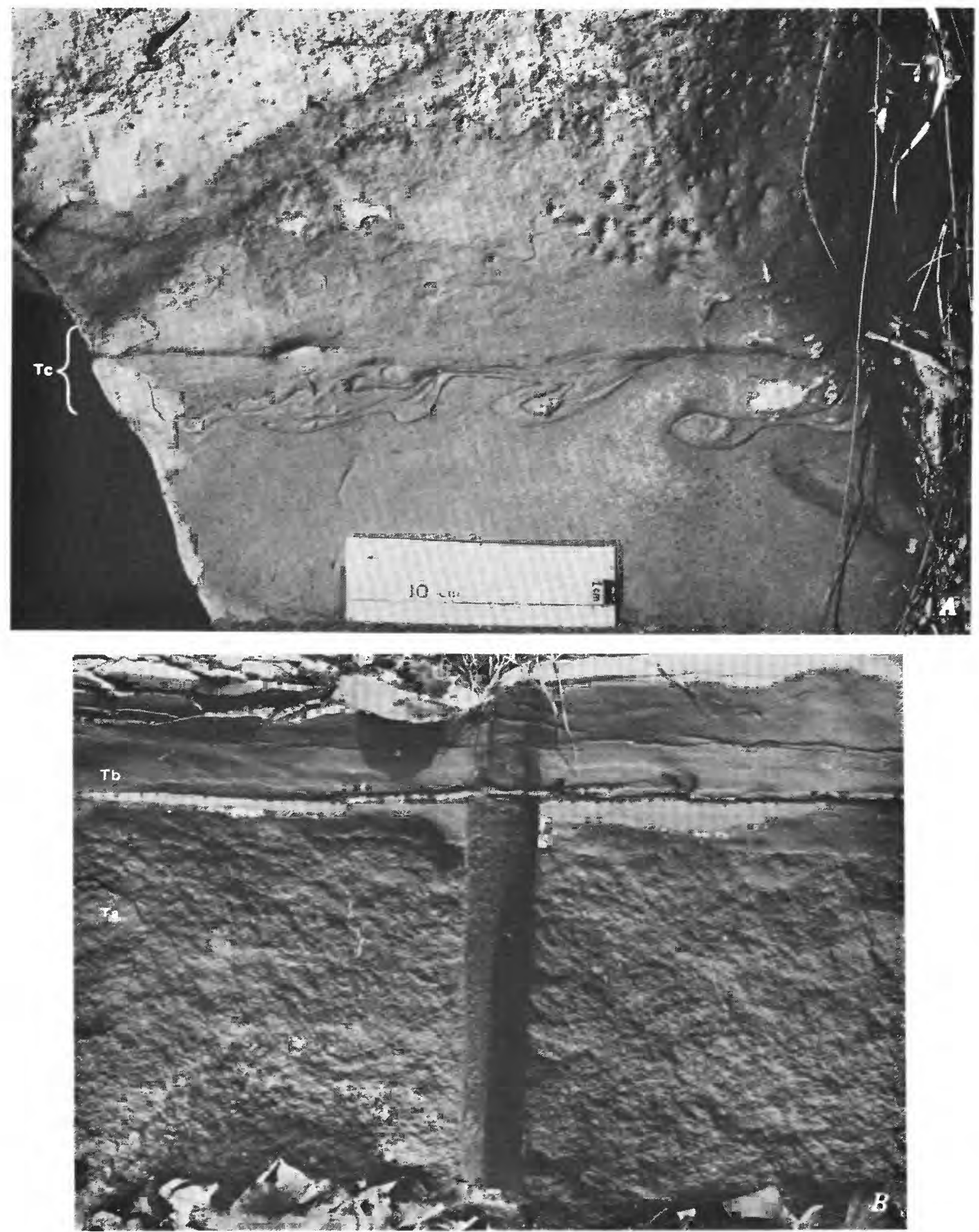

FIGURE 27.-Photographs showing internal bedding sequences in siltstone beds along Firetower Hill road, loc. 0, figure 6. $A$, Convolute laminae $\left(\mathrm{T}_{\mathrm{c}}\right.$ ) (from Bouma, 1962). $B$, Massive bedding $\left(\mathrm{T}_{\mathrm{a}}\right.$ ) overlain by laminated bedding sequence $\left(\mathrm{T}_{\mathrm{b}}\right)$ in $1.2 \mathrm{ft}$. $(36-\mathrm{cm})$ siltstone bed.

fossils throughout siltstone beds that are separated from overlying siltstone beds by only a thin seam of shale and by the relative abundance of trace fossils in the upper parts of siltstone beds overlain by shale beds thicker than $0.5 \mathrm{ft}(15 \mathrm{~cm})$.

\section{PALEOCURRENT ANALYSIS}

Sedimentary structures in the Borden Formation 


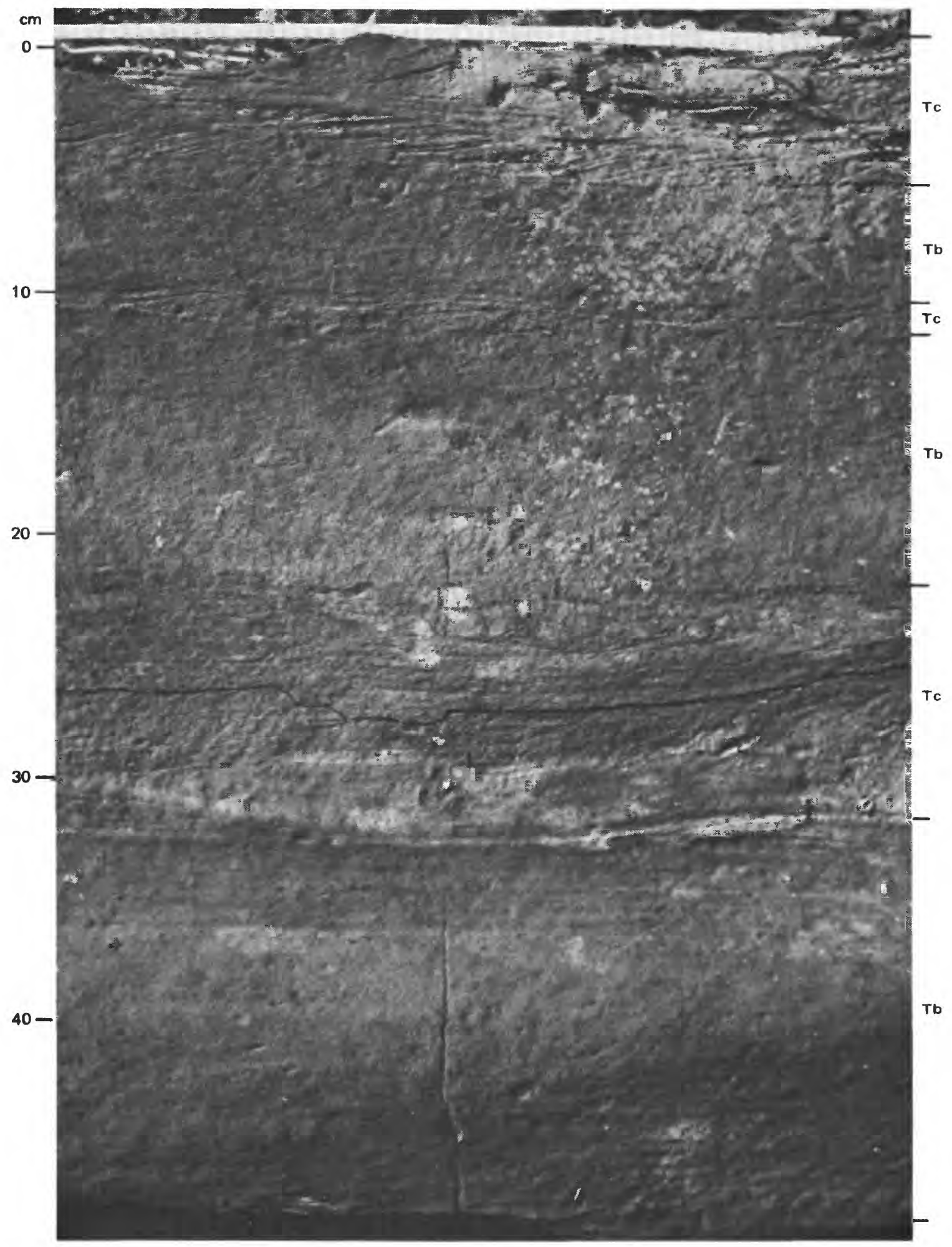

Figure 28.- Siltstone bed in Kenwood member along Pleiss Hollow, loc. B, figure 6. Basal planar lamination ( $\left.\mathrm{T}_{\mathrm{b}}\right)$ overlain in turm by layer of starved ripples $\left(T_{c}\right)$, planar $\left(T_{b}\right)$, convolute lamination $\left(T_{c}\right)$, and planar laminae $\left(T_{b}\right)$, a second layer of starved ripples $\left(\mathrm{T}_{\mathrm{c}}\right)$, more planar laminae $\left(\mathrm{T}_{\mathrm{b}}\right)$, and at the top, a zone of climbing ripples $\left(\mathrm{T}_{\mathrm{c}}\right)$. (Bouma-sequence notation explained in fig. 30.)

east of the Cincinnati arch were identified as paleocur- $\mid$ 1950; Wilson, 1950). Since then, additional data have rent indicators by Rich and Wilson (1950; also Rich, been provided for the Kenwood (Kepferle, 1968a, 1969, 

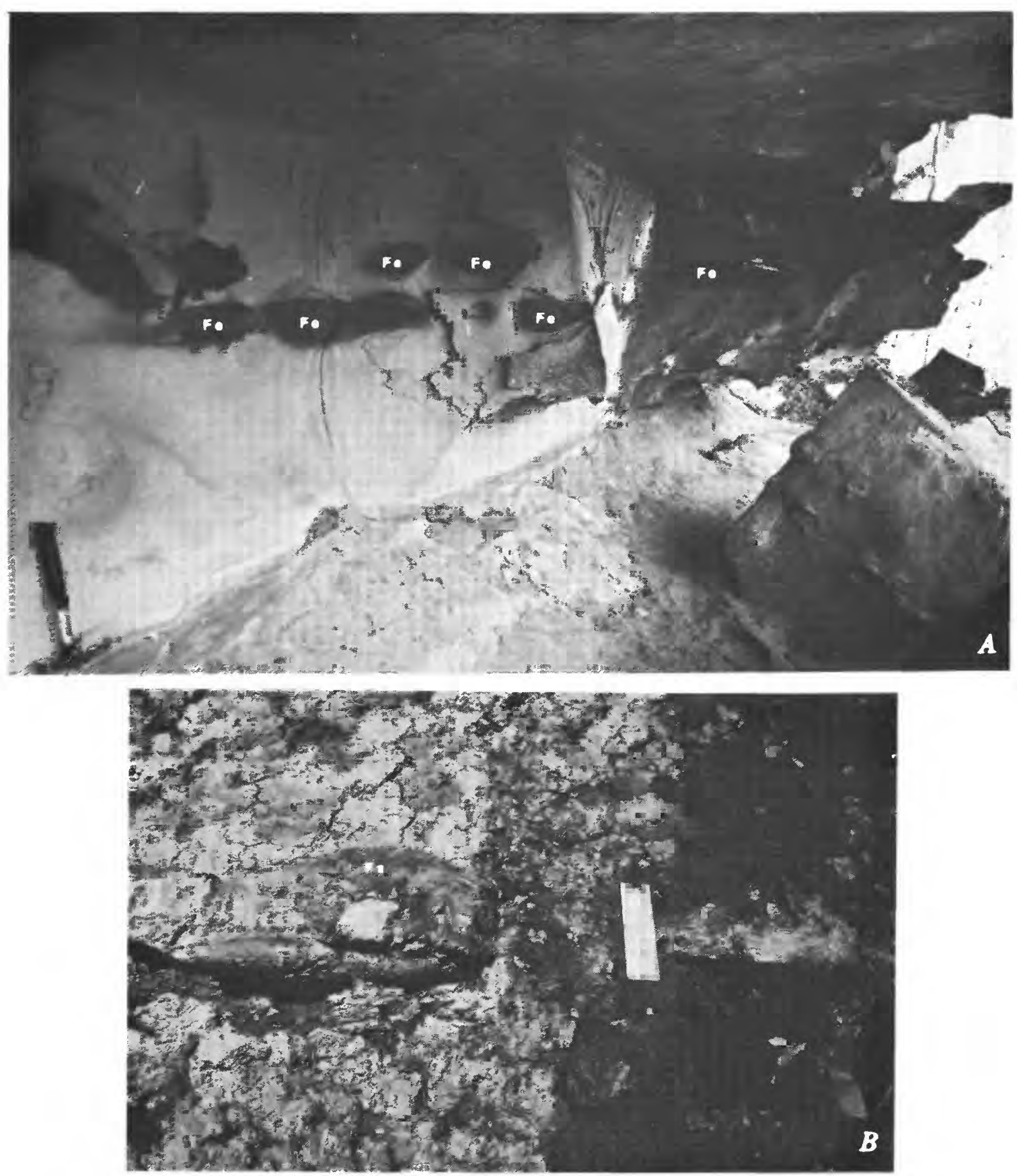

Figure 29.-Photographs showing sideritic concretions (Fe) in Kenwood Siltstone Member. $A$, Concretionary zone in middle of massive-bedded siltstone, loc. $\mathrm{N}$, figure 6 . $B$, Concretion centered on a thin siltstone bed along State Highway 61 , loc. R, figure 6 .

1972a, b, 1974), the Farmers Siltstone Member as used by Moore and Clarke (1970) and Clarke (1969), the Edwardsville Member as used by Whitehead (1973), and the "Rockcastle freestone" beds of the Wildie Member of the Borden Formation (Weir, 1970). All these studies indicate transport from east to west during Early Mississippian Borden deposition.

Linear indicators are more abundant in the Ken- wood than are unidirectional indicators and include, in decreasing order of abundance, grooves, bounce, and brush casts on the base of the beds, and parting lineation and oriented fossils within the beds. Unidirectional indicators are less than 10 percent of the total indicators measured and include prod casts, load casts, flute casts, furrow flute casts (as used by McBride, 1962 , p. 57), chevron casts on the base of beds, and 


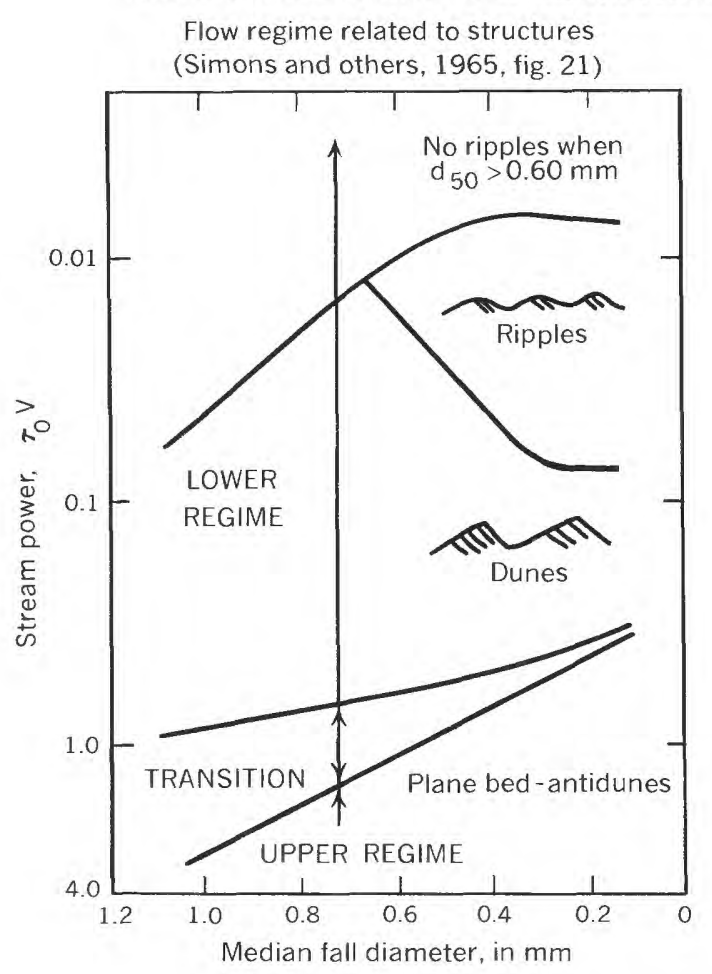

Sequence of internal bedding in turbidites (Bouma, 1962, fig. 8)

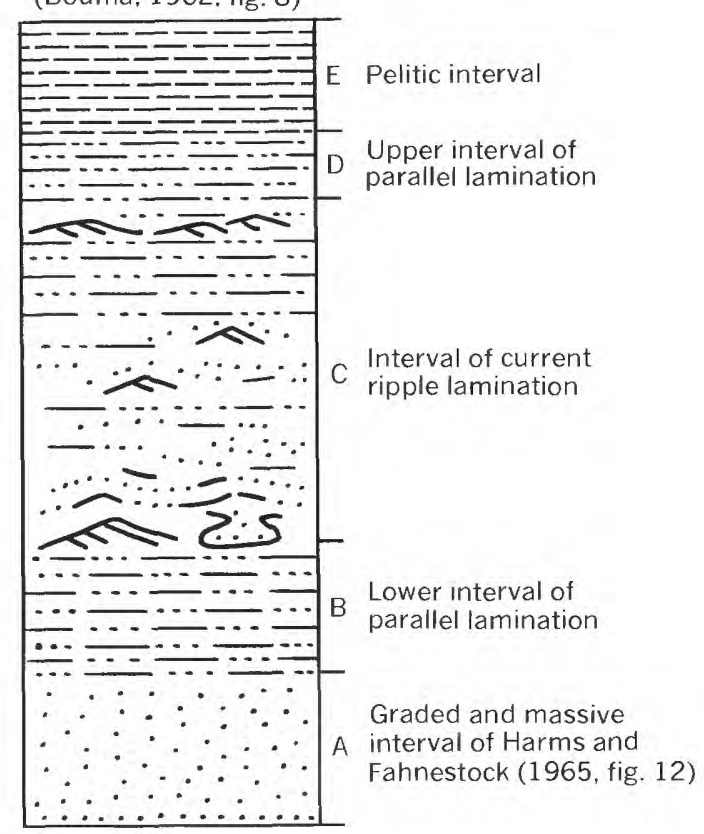

FIGURE 30.-Diagrams showing flow regime related to structures in an ideal turbidite.

ripple foresets and flame structures associated with internal convolutions within beds. Unidirectional current indicators are sufficiently abundant to permit inference of a general directional sense of the paleocurrents that deposited the Kenwood Siltstone Member of the Borden Formation.

Flute, prod, and ripple foresets are considered the most directionally sensitive of the current indicators. Clasts showing imbrication and imbricated-fossil fragments were seen in float. Drag casts, called chevron casts (Dunbar and Rodgers, 1957, p. 185), appear to have been formed by a tool being dragged across a pelitic bottom.

Flame structures have been attributed to penecontemporaneous drag during the formation of load casts. This may cause the tips of the flame structures to be bent in a downcurrent direction (Pettijohn and Potter, 1964, pl. 53B). Both upcurrent- and downcurrentdirected flame structures, however, occur in a single bed within a few inches of each other in the Kenwood.

Channels in the Kenwood were not included with the paleocurrent analysis because their orientation and continuity are too inferential.

All directional data for the Kenwood are treated as linear in the initial and summary groupings. Data are grouped according to subareas consisting of one-sixth of a $7 \frac{1}{2}$-minute quadrangle (table 3 ) and are summarized as a moving-average map and current rose (fig. 38). Vector analysis of 37 unidirectional meas- urements is based on individual rather than grouped data but is otherwise similar to the method outlined by Potter and Pettijohn (1963, p. 262-265). The resultant vector mean is $246^{\circ}$ with a standard deviation of $\pm 51^{\circ}$. Preferred orientation of $78^{\circ}-258^{\circ}$ is confirmed for the linear data by the Tukey Chi Square Test, as outlined by Rusnak (1957, p. 53-54), using nine 20-degree classes from $0^{\circ}$ to $180^{\circ}$. By comparison, the summary for the nongrouped linear data $(n=526)$ indicates a mean of $67^{\circ}-247^{\circ}$ with a standard deviation of $\pm 32^{\circ}$. Thus, the dominant paleocurrent system was to the west-southwest, normal to the strike of the Borden delta front. Paleocurrents parallel to the front were rare.

From the distribution of current sense shown on figure 38, at least two local dispersal centers are postulated. Through upcurrent projection along the moving-average linears, one of the centers appears to have been in what is now easternmost Jefferson County, Ky., the other in what is now western Spencer County, Ky. (See fig. 1.) Vector means calculated for directional data from the two separate areas differ from each other by less than $2^{\circ}$. This suggests that the mode and amount of dispersion from both postulated centers were about the same.

\section{PROVENANCE}

A source area composed mainly of plutonic rocks and 

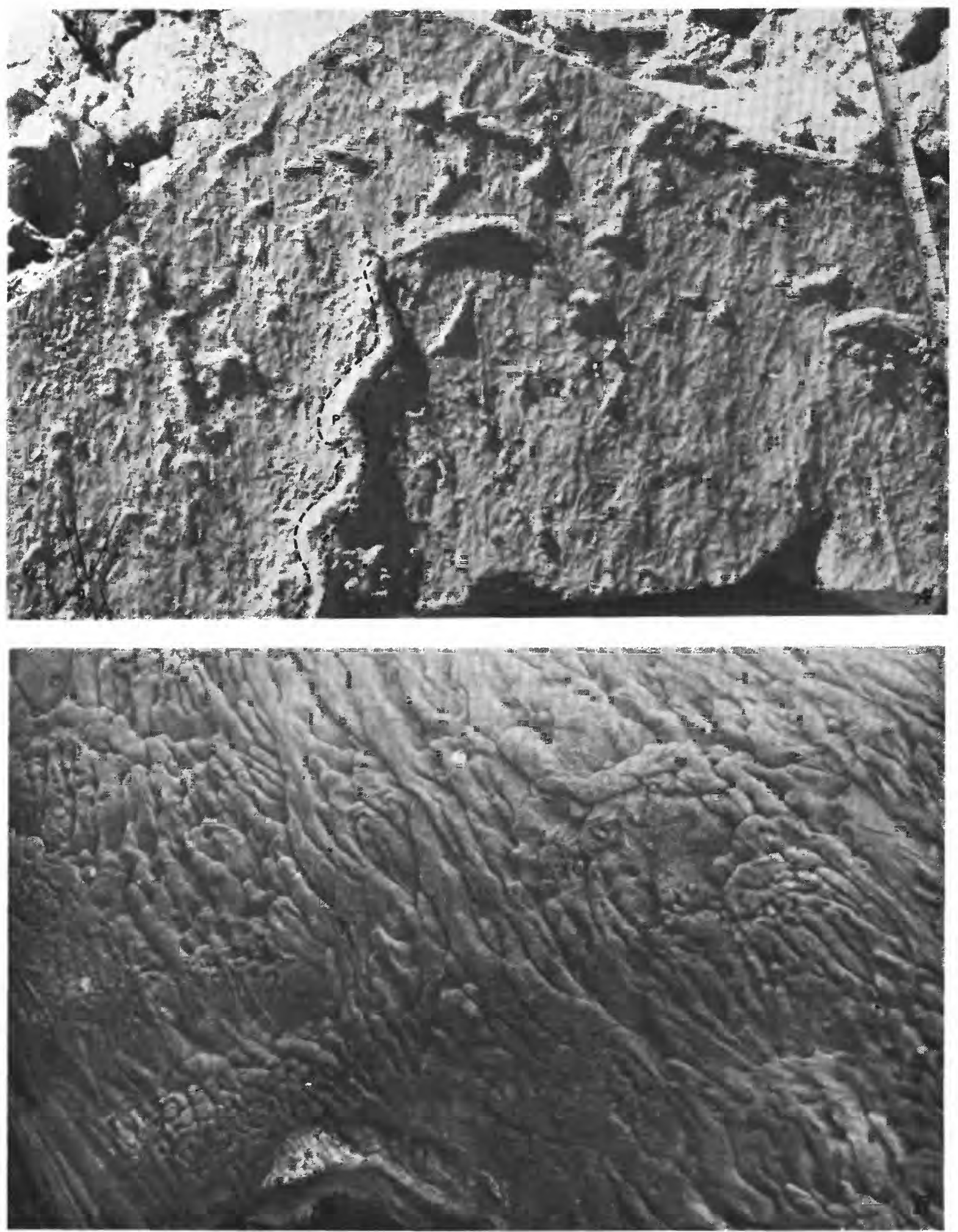

FIgURE 31.-Photographs showing sole marks on siltstone beds of the Kenwood Siltstone Member. A, Two sets of grooves (g) and a sinuous trace fossil, possibly Planolites sp. (P), loc. N, figure 6. B, Load casts with bulbous ends pointing downcurrent as established from nearby chevrons associated with groove casts, loc. N, figure 6 .

including some sedimentary and metamorphic rocks is suggested by the freshness of some of the feldspar, the angularity of the grains, and the dominance of $\mathrm{K}$-feldspar over plagioclase, as well as the sodic nature 
of the plagioclase. The wide range of weathering shown by the feldspar, and the immaturity reflected by the general angularity of grains and the high matrix content, suggest that the relief of the source area was moderately high. Hence, the source area may have been tectonically active. The weathered feldspar also indicates that the climate was humid in part.

The lack of sand coarser than very fine in any of the Borden sediment in the study area indicates that the dispersal center was distant. The lack of maturity indicates that deposition was rapid.

Analyses of paleocurrent structures indicate an easterly source for the silt in the Kenwood Siltstone, the Farmers, and the "Rockcastle freestone" beds of the Wildie Members of the Borden Formation (fig. 39). The Mississippian Berea Sandstone is postulated by Pepper, de Witt, and Demarest (1954, p. 99) to have originated in eastern Canada, in that heavy minerals preclude a granite-cored Appalachia as a direct source of first-generation sand. The source of siltstone for the Kenwood, the Farmers, and the "Rockcastle freestone" beds is postulated as a granite-cored Appalachia. Thus, it appears that the source of sand in the Berea was not the same as that for the silt in the Kenwood.

A highland source to the east and southeast has been postulated by Bartlett (1974) for the Lower Mississippian Price Formation in southwest Virginia; this source is suggested mainly from an eastward thickening of the Price and by isolith and lithofacies maps of the Price. Bartlett correlated all but the uppermost member of the Price with the Grainger Formation in Tennessee. In a petrologic study of the Grainger Formation, Hasson $(1972$, p. 54, 57) found that the upper sandstone in the Grainger is arkosic and that potassium feldspar and plagioclase are found in the proportion of 10 to 1 . Because this proportion is similar to that in the Borden siltstone I have studied and because the Borden Formation correlates stratigraphically with the Grainger and the Price Formations, the source of the terrigenous clastic materials in the Borden Formation must have been to the east and southeast, similar to that of the Grainger and Price Formations.

\section{DEPOSITIONAL MODEL}

The siltstone beds of the Kenwood Siltstone Member of the Borden Formation were probably deposited from sediment carried by turbidity currents, which spread out from the edge of a prograding delta platform. The turbidite nature of these beds is indicated by their similarities to key features of ancient and modern turbidites: geometry, petrology, structures, fauna, and the nature of the enclosing sediment (Cline, 1970, p. 89 91; Kuenen, 1964 , p. 10-13), as shown in table 4.

Only two of the listed criteria have not been recognized in the Kenwood: one is a correlation between bed thickness and maximum grain size; the other is the presence of plant remains (table 4, Nos. 25, 26).

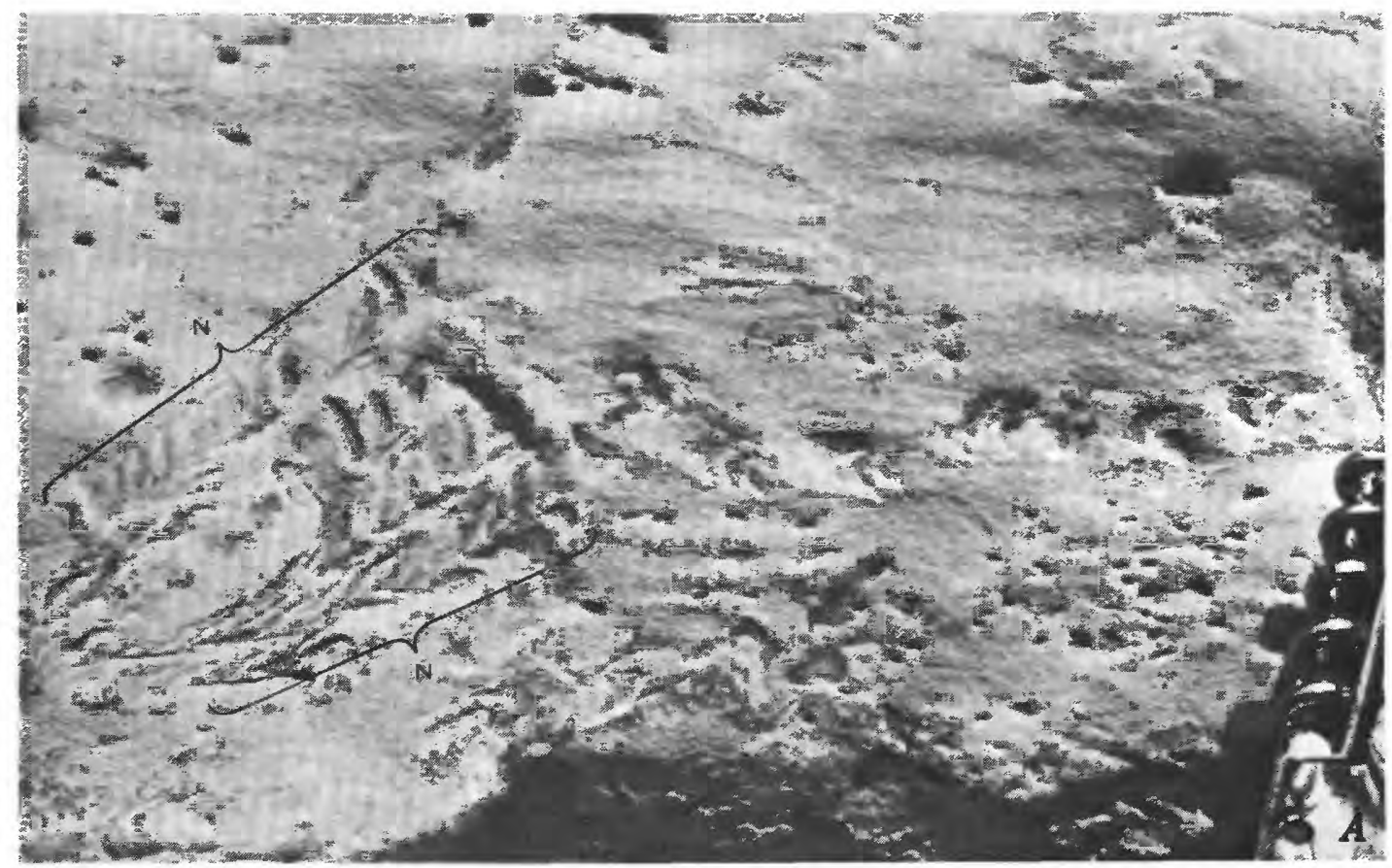

FIGURE 32.-Photographs showing trace fossils. A, Nereites-like pattern (N) in vertical cross section of bed; possibly related to Zoophycos sp., as in $C$; loc. 0, figure 6. Photograph by W. A. Pryor. B, Zoophycos-like form(z) with crescentic burrow (c), loc. R, figure 6. C, Larger Zoophycos-like form, loc. 0, figure 6. 
EVIDENCE FROM STRATIGRAPHY

Stratigraphically, the Kenwood is part of a mass of sediment believed to be of deltaic origin (Swann and others, 1965; Lineback, 1966, 1968a; Peterson and Kepferle, 1970). Recent studies of modern deltas have found turbidites as part of the prodelta cone (Ewing
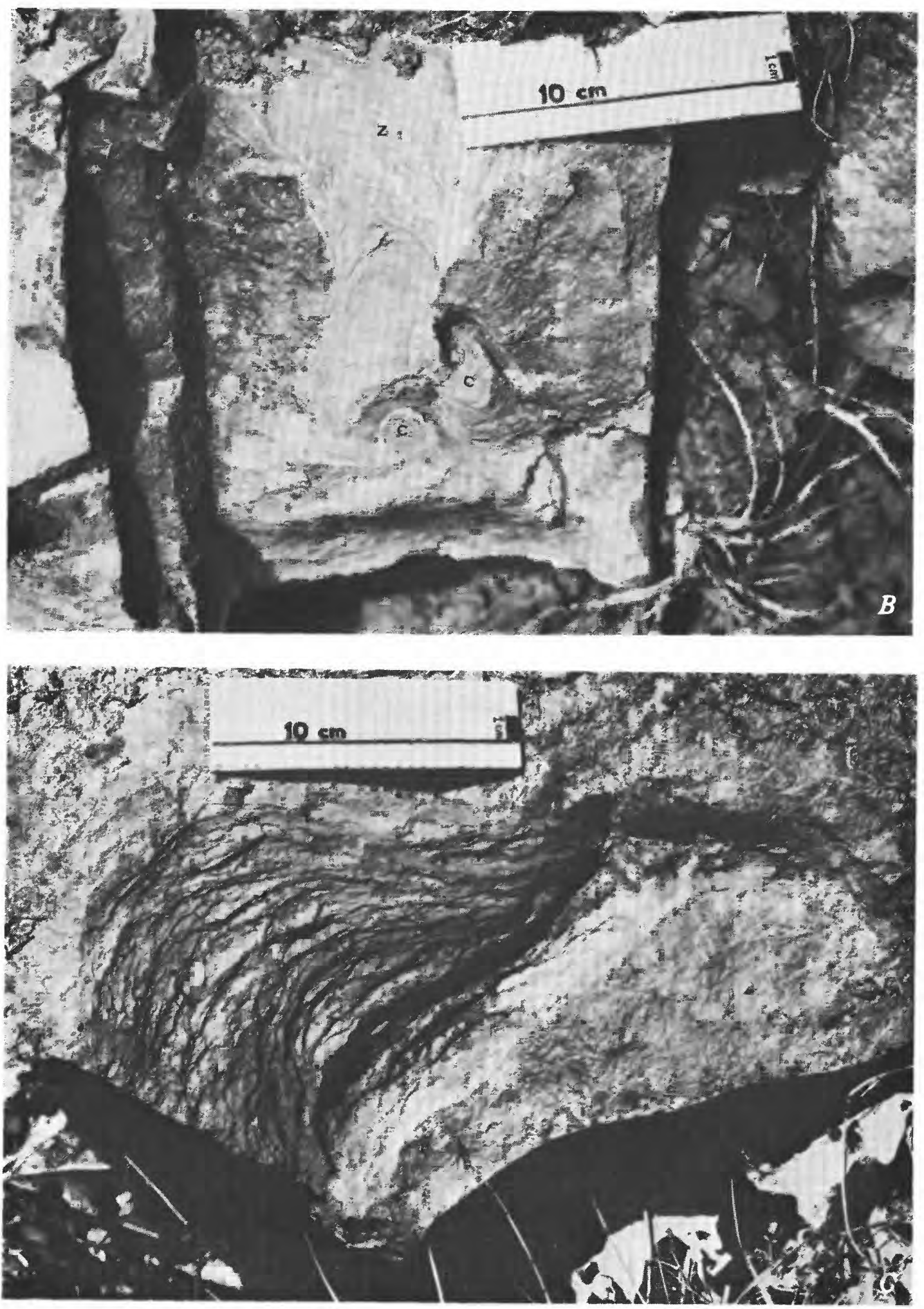

Figure 32.- Continued. 

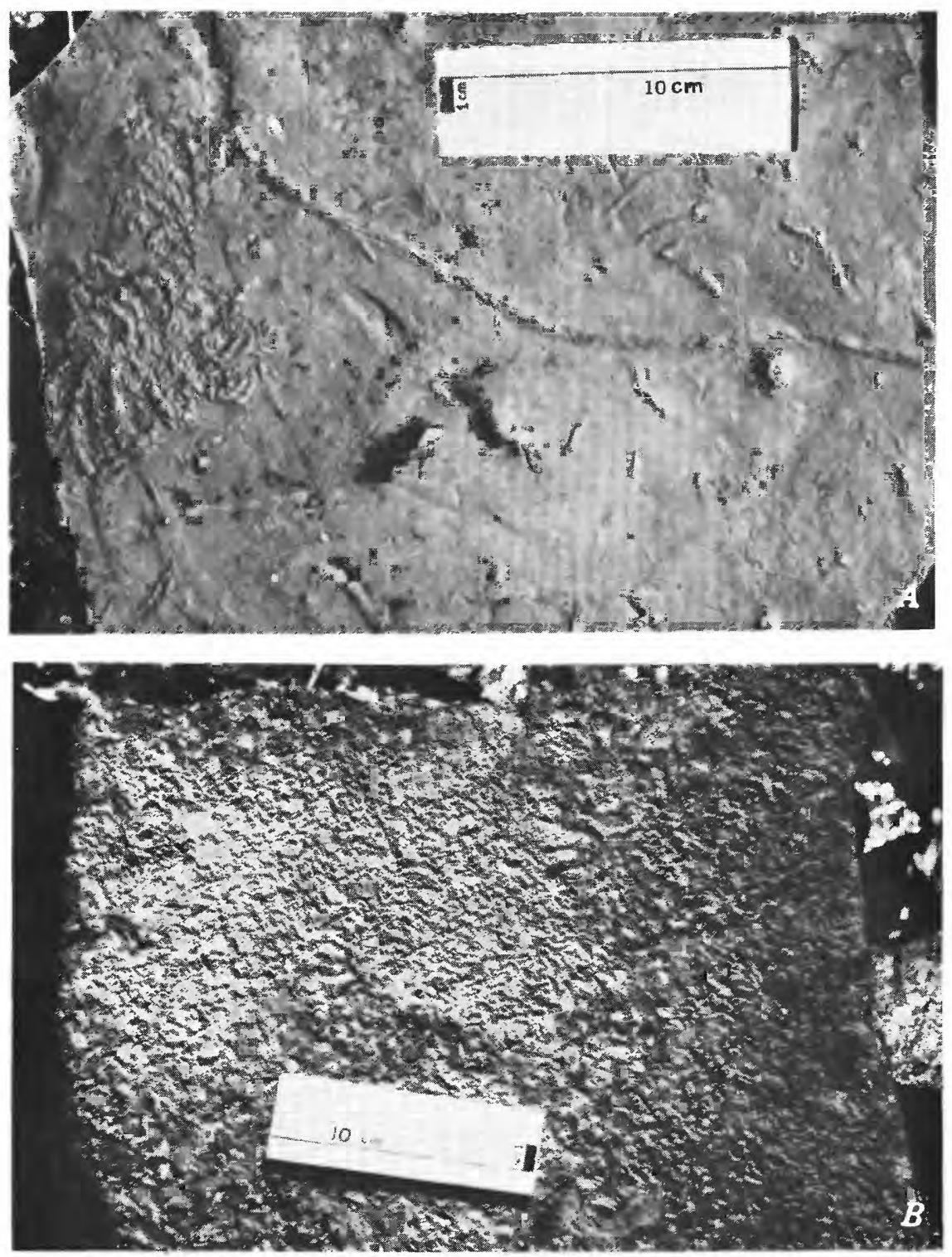

Figure 33.-Photographs showing trace fossils of Pascichnia affinities, loc. Q, figure 6. $A$, Lophoctenium sp. $B$, Unidentified Pascichnia.

and others, 1958; Shepard, 1951; Phleger, 1951). I suggest that the Kenwood is the turbidite facies of a deltaic environment.

Many turbidite characteristics listed in table 4 are applicable to the Kenwood and indicate a turbidite origin for its siltstone. In common with ancient and modern turbidites, the siltstone beds of the Kenwood alternate with the finer shale beds (table 4, No. 1 ). The shale beds lack all evidence of shallow-water deposition (table 4, No. 2) and show little change in bedding and composition from that of the underlying New Providence Shale Member of the Borden Formation (table 4, No. 3).
The thickness of the siltstone beds ranges from less than $0.1 \mathrm{ft}(3 \mathrm{~cm})$ to as much as $20 \mathrm{ft}(6 \mathrm{~m})$ and averages about $0.5 \mathrm{ft}(15 \mathrm{~cm})$ (table 5, No. 17). The siltstone beds are thickest near the dispersal centers inferred from paleocurrent data and are thinner distally (table 4, No. 21). This is true also for the overall geometry of the Kenwood, which is thickest near the postulated dispersal centers. The slope on which the siltstone beds were deposited was generally less than $1^{\circ}$ (table 4 , No. 18) and is regarded as representative of the slope on the sea bottom during the time of deposition.

The fewer than 40 beds within a vertical sequence of the Kenwood indicate a triggering mechanism of short 

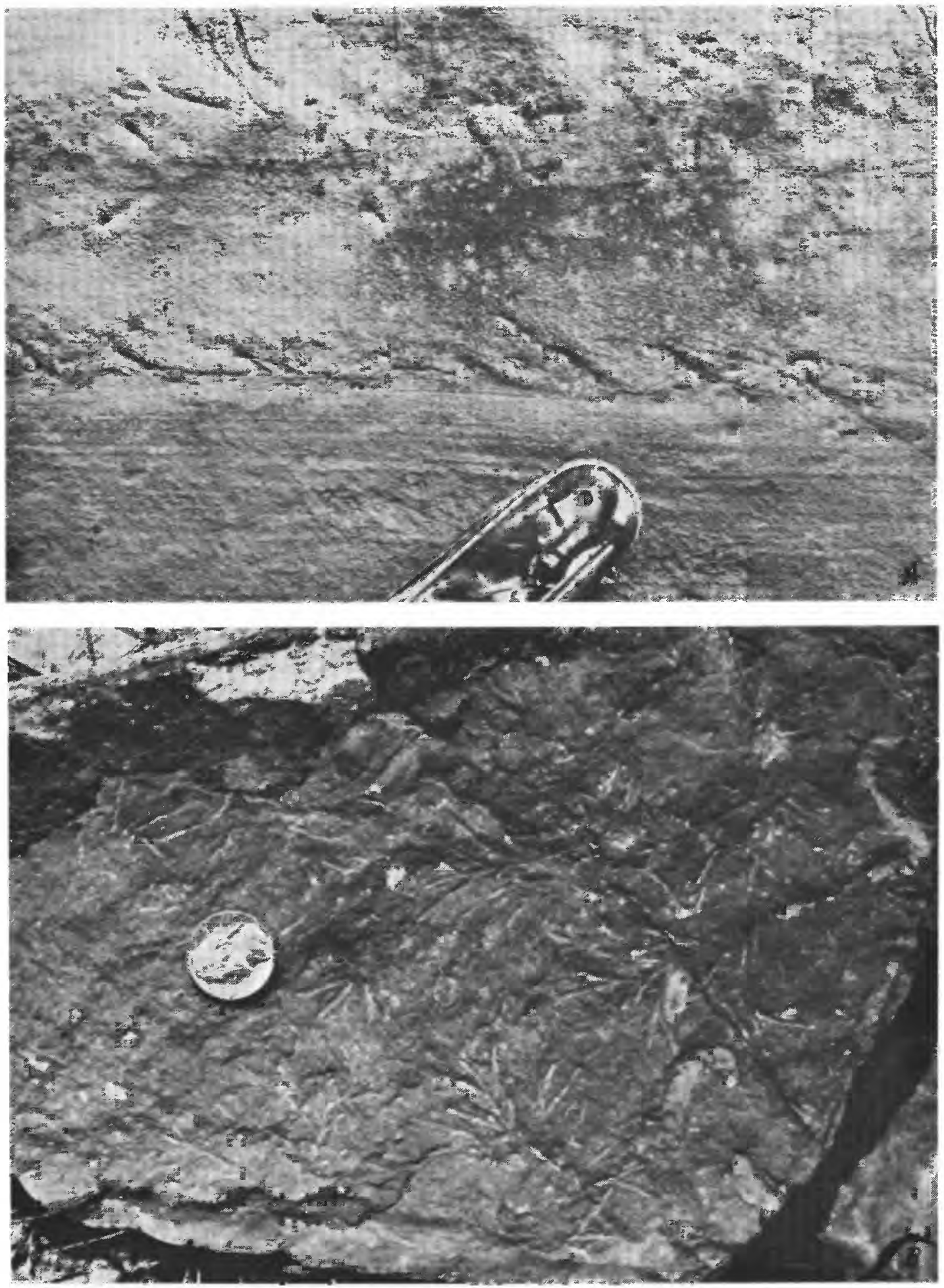

Figure 34.-Photographs showing trace fossil Chondrites sp. $A$. In a vertical section (loc. $\mathrm{O}$, fig. 6 ) associated with flame structure along a possible amalgamated contact above which is massive bedding and below which is planar-laminated bedding. Photograph by W. A. Pryor. B. Along bedding-plane surface, loc. R, figure 6.

duration and moderate intensity, be it seismic shock, storm, hyperpycnal currents, or simply oversteepening along the upper margin of the slope.

\section{EVIDENCE FROM PETROLOGY}

Compositional and textural similarities between the Kenwood and known turbidites would seem logically to 

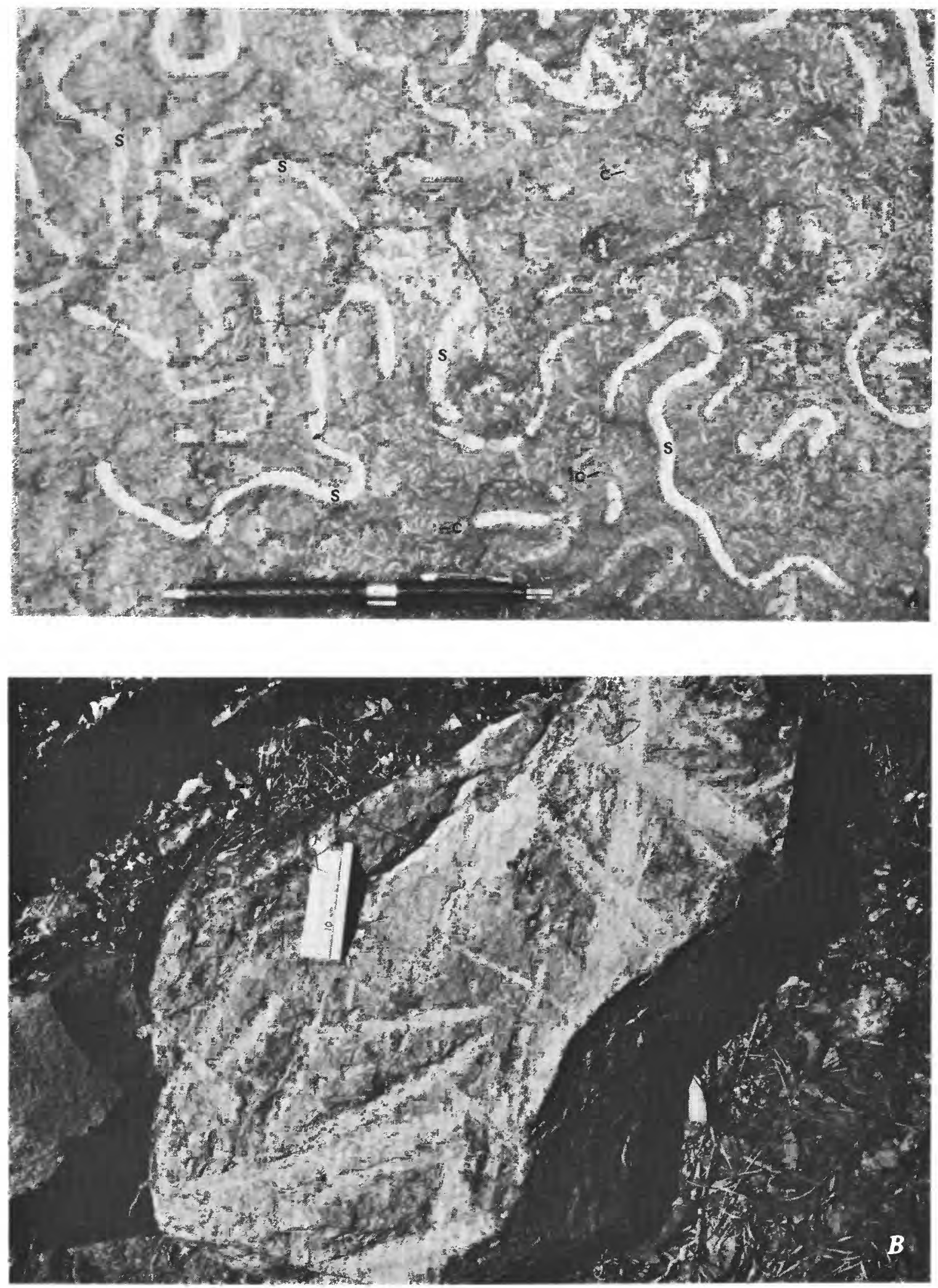

FIGURE 35.-Photographs showing trace fossils of Fodinichnia affinities. A, Scalarituba missouriensis Weller (S) with smaller Cosmorhaphe? sp. (C) on upper surface of siltstone bed along St. Andrews Church Road, loc. D, figure 6.B, Orthoconic cephalopod? trails, loc. N, figure 6. 


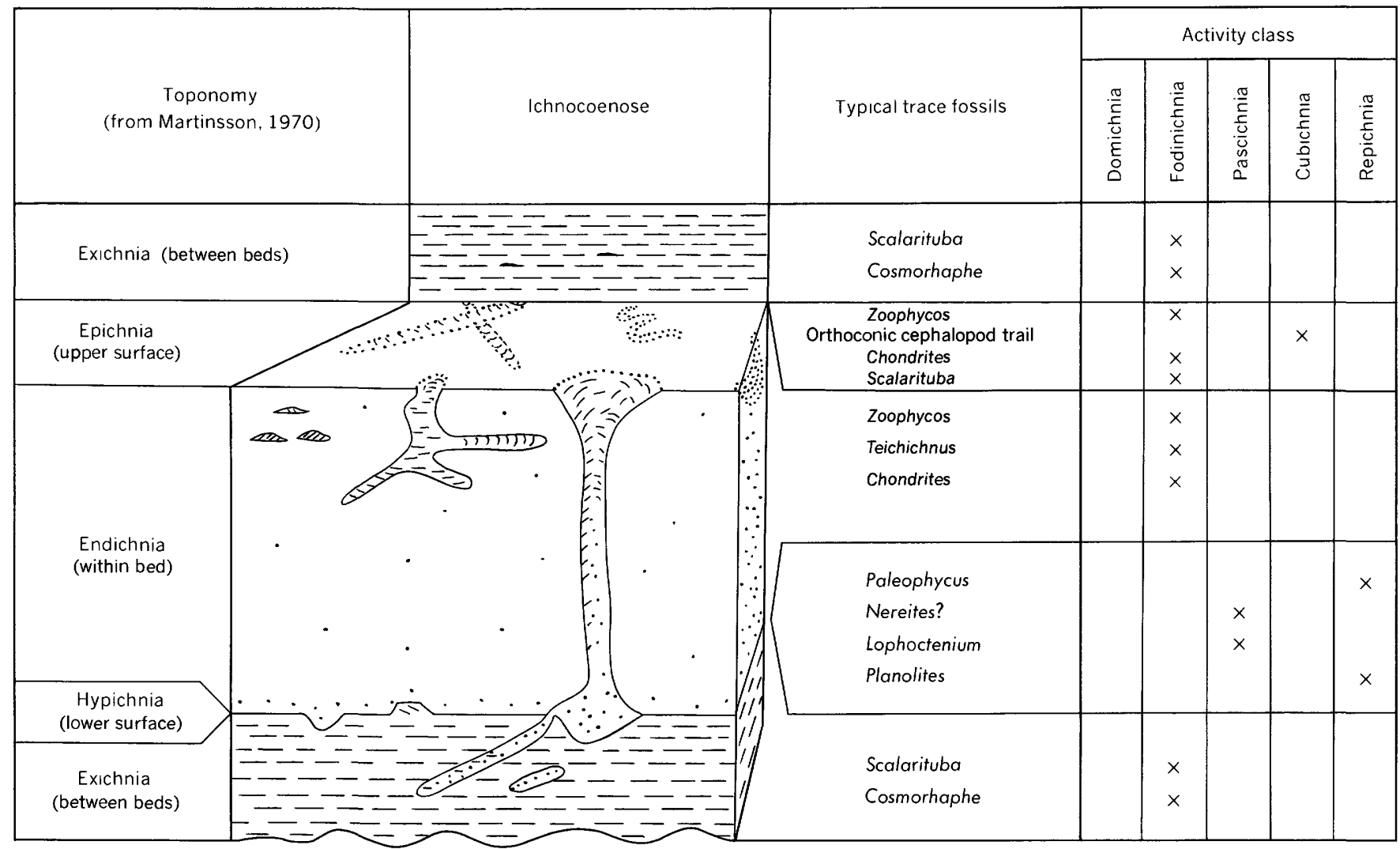

FigURE 36.-Diagrammatic classification of the trace fossils of the Kenwood according to toponomy and activity class. (Domichnia, dwelling burrow; Fodinichnia, feeding burrow; Pascichnia, feeding trail; Cubichnia, resting trail; Repichnia, crawling trail; after Seilacher, 1953).

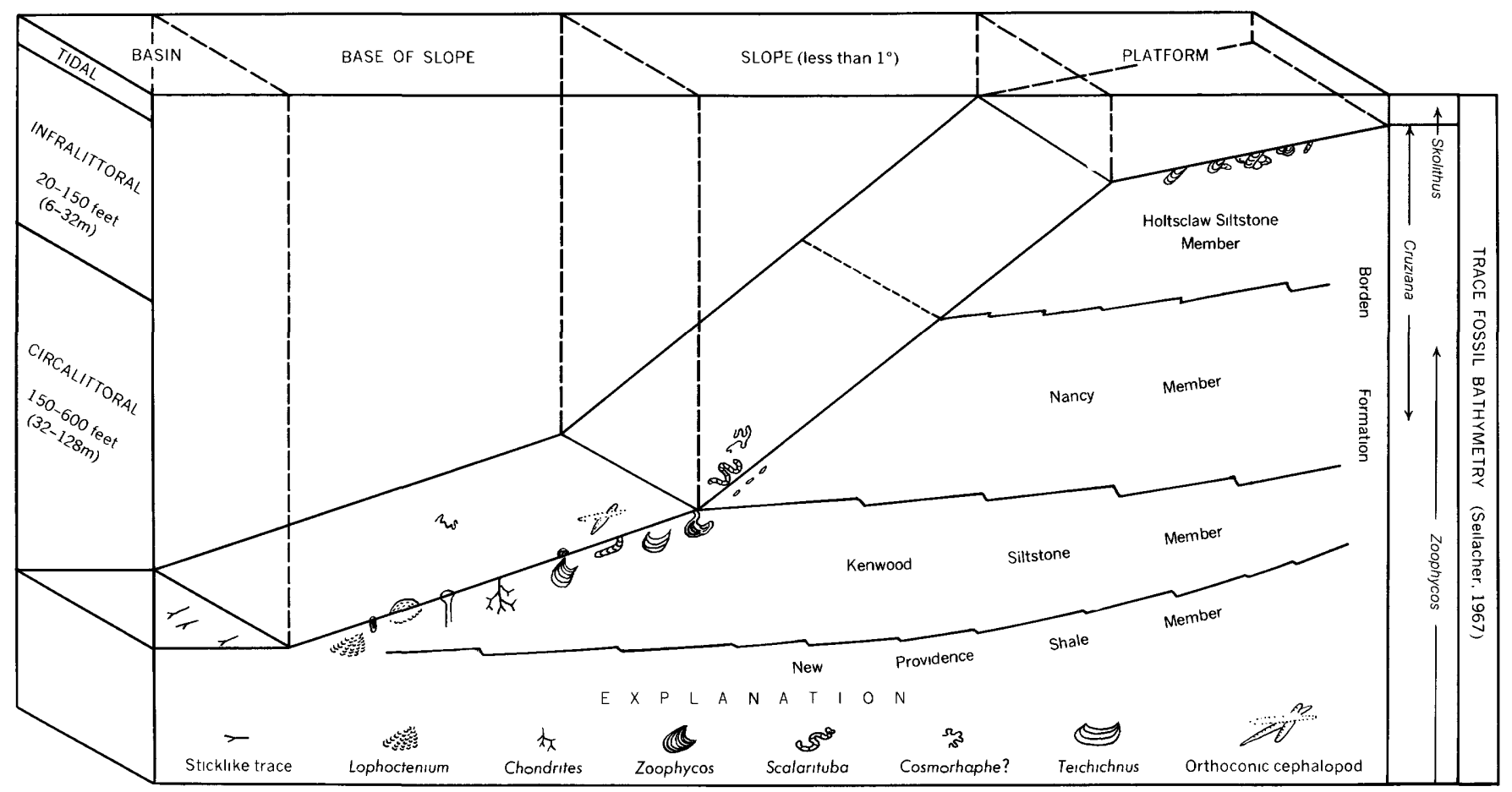

FigURE 37.-Diagrammatic ichnocoenose of the Borden delta front. 
TABLE 3.-Linear directional indicators in the Kenwood Siltstone Member of the Borden Formation [Total standard deviation: $\pm 32^{\circ}$ ]

\begin{tabular}{|c|c|c|c|c|c|}
\hline Quadrangle & Sector & $\begin{array}{c}\text { Obser- } \\
\text { vations }\end{array}$ & $\begin{array}{c}\text { Linear } \\
\text { mean } \\
\text { (degree) }\end{array}$ & $\begin{array}{l}\text { Vector } \\
\text { length }\end{array}$ & $\begin{array}{l}\text { Length } \\
\text { (percent) }\end{array}$ \\
\hline $\begin{array}{l}\text { New Albany } \\
\text { Do. } \\
\text { Georgetown } \\
\text { Lanesville } \\
\text { Louisville West } \\
\text { Do. } \\
\text { Do. } \\
\text { Do. } \\
\text { Do. } \\
\text { Valley Station } \\
\text { Do. } \\
\text { Do. } \\
\text { Do. } \\
\text { Do. } \\
\text { Brooks } \\
\text { Do. } \\
\text { Do. } \\
\text { Pitts Point } \\
\text { Shepherdsville } \\
\text { Do. } \\
\text { Do. } \\
\text { Samuels } \\
\text { Do. } \\
\text { Lebanon Junction } \\
\text { Cravens } \\
\text { New Haven }\end{array}$ & $\begin{array}{l}\text { WC } \\
\text { SW } \\
\text { SE } \\
\text { NE } \\
\text { NW } \\
\text { WC } \\
\text { SW } \\
\text { EC } \\
\text { SE } \\
\text { NW } \\
\text { NE } \\
\text { WC } \\
\text { SE } \\
\text { EC } \\
\text { NW } \\
\text { WC } \\
\text { SW } \\
\text { NE } \\
\text { EC } \\
\text { SW } \\
\text { SE } \\
\text { WC } \\
\text { SW } \\
\text { SE } \\
\text { WC } \\
\text { WC }\end{array}$ & $\begin{array}{r}3 \\
9 \\
4 \\
4 \\
2 \\
12 \\
35 \\
3 \\
126 \\
23 \\
19 \\
6 \\
4 \\
1 \\
11 \\
41 \\
40 \\
1 \\
20 \\
14 \\
57 \\
13 \\
45 \\
13 \\
19 \\
1\end{array}$ & $\begin{array}{l}83 \\
72 \\
82 \\
78 \\
85 \\
62 \\
70 \\
70 \\
82 \\
65 \\
62 \\
59 \\
42 \\
50 \\
54 \\
56 \\
61 \\
50 \\
86 \\
53 \\
89 \\
43 \\
85 \\
59 \\
16 \\
35\end{array}$ & $\begin{array}{r}2.96 \\
8.79 \\
3.96 \\
3.96 \\
1.99 \\
11.84 \\
34.08 \\
3.00 \\
87.27 \\
22.70 \\
18.57 \\
5.92 \\
3.77 \\
10.72 \\
39.64 \\
38.20 \\
15.18 \\
13.24 \\
46.94 \\
9.96 \\
39.74 \\
9.64 \\
17.17 \\
--.- \\
\end{array}$ & $\begin{array}{r}98.6 \\
97.7 \\
98.9 \\
98.9 \\
99.6 \\
98.7 \\
97.4 \\
100.0 \\
69.3 \\
98.7 \\
97.5 \\
98.8 \\
94.4 \\
100.0 \\
97.4 \\
96.7 \\
95.5 \\
100.0 \\
75.9 \\
94.6 \\
82.3 \\
76.6 \\
88.3 \\
74.2 \\
90.4 \\
100.0 \\
\end{array}$ \\
\hline Summary & & 526 & 67 & 168.36 & 31.9 \\
\hline
\end{tabular}

be independent, as they are governed in part by the nature of the source sediment. In common with turbidites, however, the silt of the Kenwood is rich in feldspar, angular quartz, mica, and pyrite and contains traces of glauconite (table 4, No. 20). A lag concentrate of ostracode tests found in bed four on Kenwood Hill (loc. E, fig. 6, sample LW-1-40, fig. 23) is a characteristic found in other turbidites (table 4, No. 23), as is the occurrence of mud galls in the base of a Kenwood siltstone bed in the vicinity of Shepherdsville, $\mathrm{Ky}$. (table 4, No. 19).

Texturally, the original sediment in the coarsest beds is mainly coarse silt (table 4 , No. 4), for which sorting is poor (table 4, No. 13). No correlation was found between bed thickness and grain size, as is reported for most turbidites (table 4, No. 25).

\section{EVIDENCE FROM BEDDING STRUCTURES}

Internal sedimentary structures. -Obvious grading is rare in the Kenwood because of the minute variations in grain size of the siltstone. The basal massive layer, $\mathrm{T}_{\mathrm{a}}$ of the Bouma sequence (fig. 30), is commonly referred to as the graded layer, but in fact, the entire bed may be graded in the sense of Kuenen (1953, p. 1049): "The lower, main part of a graded bed is generally massive $e^{* * *}$. The upper part is slightly or distinctly laminated." Size analyses of the Kenwood in table 2 indicate internal grading of an entire bed, defined mainly by the percentage of the coarsest fraction measured in a given bed. A comparison of cumulative curve parameters of grain-size analyses of the basal, middle, and uppermost parts of nearly every bed examined shows this grading. A comparison of median-grain size also shows the same fining-upward tendency, but the upper parts of most beds are gradational with the overlying pelite, $\mathrm{T}_{\mathrm{e}}$ of the Bouma sequence, and, as shown in the photomicrograph in figure $18 A$, contain additional clayey material introduced as burrow fillings.

The shale beds in the Kenwood represent the tails of the turbidity currents, $\mathrm{T}_{\mathrm{e}}$ of the Bouma sequence, and pelagic sedimentation. The occurrence of siderite nodules within shale beds is suggested as one possible indicator of the presence of the $\mathrm{T}_{e}$ interval where the basal part of the sequence $\left(T_{a}\right.$ through $T_{d}$ ) may not have been deposited.

External sedimentary structures.-As characteristic of ancient and modern turbidites, the Kenwood siltstone beds have abrupt bases that commonly show sole marks (table 4, Nos. 6, 7). Because the sole marks are molds of the surface on which the beds were deposited, they are an indication of the flow regime of the depositing current. As such, sole marks are also indicators of the distance from dispersal centers of the currents (Walker, 1967).

Inasmuch as the highest flow regime attained by a turbidity current is probably reached at the foot of the slope on which the current was generated, flute casts are reported by Walker (1967) to be more prominent in proximal turbidites, whereas grooves predominate in distal turbidites. Groove casts are common throughout the siltstone beds of the Kenwood. Flute casts are common mainly in the eastern exposures, and there, some of the thicker beds show completely smooth basal surfaces. The presence of flutes may indicate beds deposited under conditions of the upper flow regime, whereas the presence of only grooves may indicate deposition under conditions of a somewhat lower flow regime. Hence, an eastern source for the depositing currents is indicated by the distribution of types of sole marks in the Kenwood as well as by the directional structures of the sole marks.

All gradations of substrate planation have been observed in the Kenwood. Some trace-fossil burrows show rims truncated by brush casts or grooves, indicating that the burrows were formed before the siltstone beds were emplaced. In the more distal siltstone beds of the Kenwood, trace fossils were emplaced after deposition of the siltstone, as is indicated by destruction of the current-scoured or tool-marked surface by trails made by browsing or burrowing organisms (fig. 34).

A summary of geometry and external features useful in determining proximal and distal parts of turbidite sequences proposed by Walker (1967) is applied to the Kenwood in table 5 . 


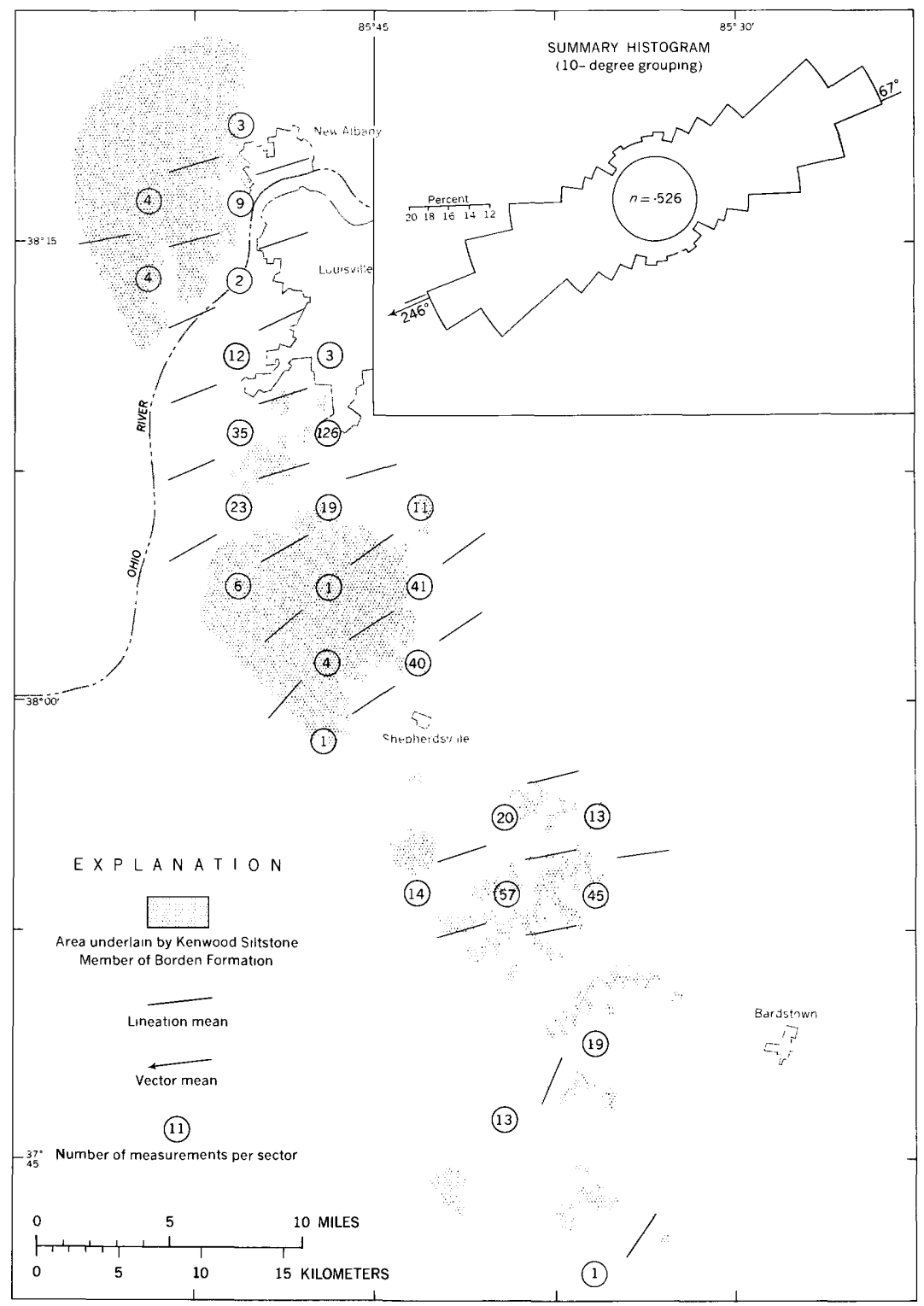

FIGURE 38.-Moving-average map and summary histogram of paleocurrent lineations and vectors, Kenwood Siltstone Member.

\section{BASIN GEOMETRY}

Paleocurrents dominantly parallel to the long dimension of the turbidite unit indicate a trough fill; paleocurrents perpendicular to the long dimension of the unit indicate a basin-marginal fill (Walker, 1970, p. 223-227). The west-southwest trend of the Kenwood paleocurrents, perpendicular to the north-northwest axis of the member, indicates it is a basin-marginal rather than a trough-filling turbidite sequence.

The northwestward trend of the basin margin during the deposition of the Kenwood is paralleled in the Lower Mississippian sequence of central Kentucky by at least three other stratigraphic features: the Holtsclaw Siltstone Member of the Borden Formation, the Knifley Sandstone Member of the Fort Payne Formation, and the Borden delta front-the boundary between the Borden and the Fort Payne Formations (fig. 5). These features, like the Kenwood, have a primary depositional dip to the west-southwest (Hrabar and others, 1971; Sedimentation Seminar, 1972, p. 4). That the Kenwood is older than these other features implies that the general orientation of this part of the basin persisted throughout most of the Early Mississippian. 


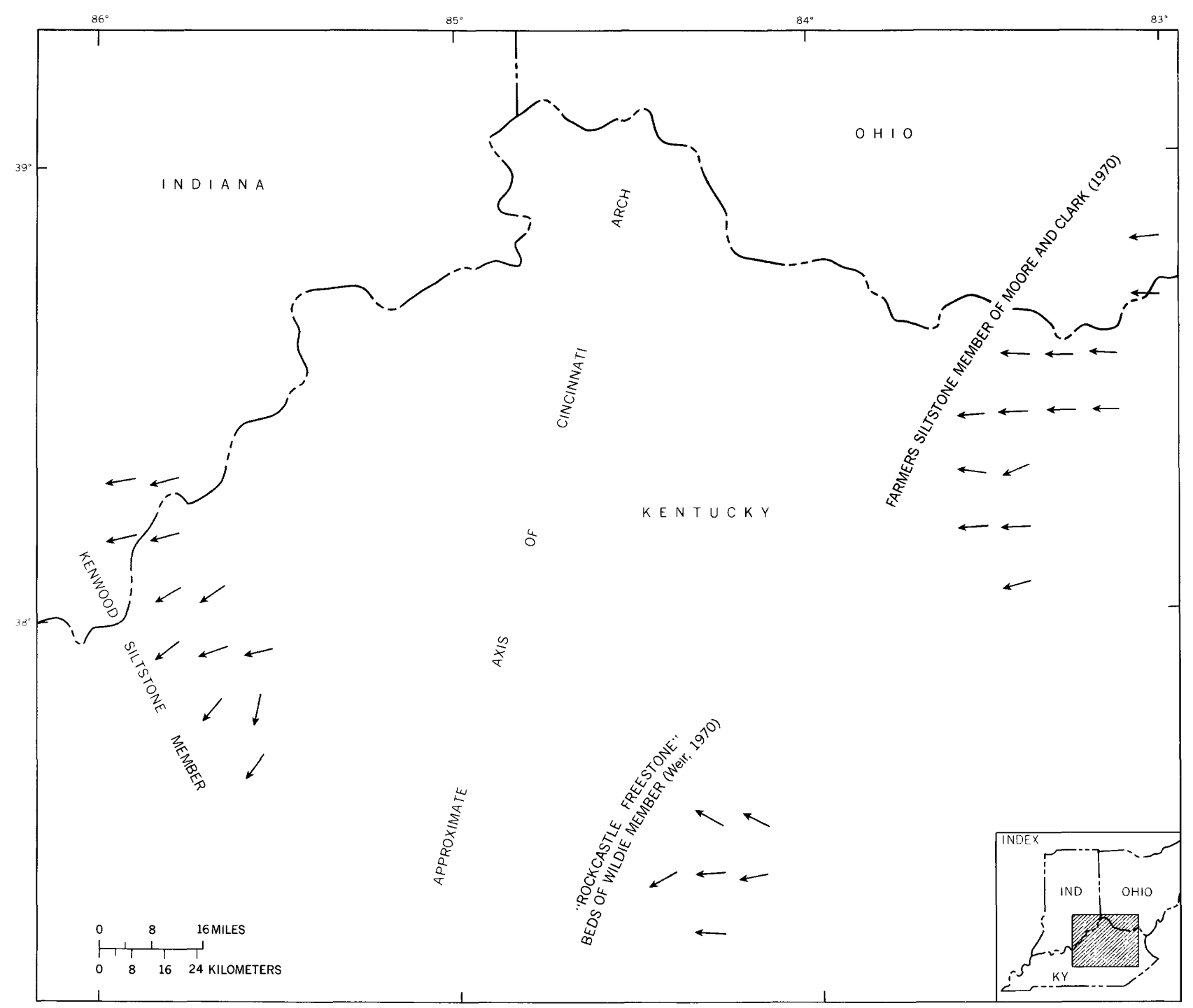

FIGURE 39.-Sketch map showing paleocurrents in the Borden Formation in Kentucky.

A vertical dimension of the basin geometry can be found, according to Klein (1974), by taking the total thickness of the prograding deltaic sequence. This thickness, from the base of the Borden to the top of the Holtsclaw Siltstone Member in the central part of the study area (section K-M, fig. 9), is $375 \mathrm{ft}(114 \mathrm{~m})$; the thickness of the sequence from the base of the Kenwood to the top of the Holtsclaw is $265 \mathrm{ft}(81 \mathrm{~m})$. This compares with basinal deltas in European Carboniferous sequences that range in thickness from $31.40 \mathrm{~m}$ to $89.32 \mathrm{~m}$ as cited by Klein (1974, table 1). During the deposition of the Kenwood turbidites, the eastern margin of the basin lay immediately east of and parallel to the north-northwest-trending Kenwood, and the basin floor sloped gently westward at less than $15 \mathrm{ft} / \mathrm{mi}$ $(2.8 \mathrm{~m} / \mathrm{km})$ in water deepening from 265 to $375 \mathrm{ft}$ ( 81 to $114 \mathrm{~m})$.

\section{SUBSEA FAN MODEL}

Submarine canyons long have been considered an appropriate environment for the occurrence of turbidity currents; the probable depositional sites of turbidites, logically, was assumed to be the subsea fan at the mouth of the canyon (Ericson and others, 1952; Bates, 1953). Sampling programs have substantiated this (Gorsline and Emery, 1959; Bouma and Shepard, 1964; Piper and Normark, 1971). Although some of the findings concerning modern and ancient subsea fans are applicable directly to the Kenwood, many of the characteristics of these fans are not represented clearly in the Kenwood. These characteristics come under the broad headings of location, geometry, fabric, sedimentary structures, and fossil content (table 6).

Characteristics.-From the discussion of basin 
TABLE 4.-Characteristics of turbidites in ancient and modern environments and comparison with features of the Kenwood Siltstone Member of the Borden Formation

\begin{tabular}{|c|c|c|c|}
\hline \multirow{2}{*}{$\begin{array}{l}\text { Ancient and modern turbidites } \\
\text { (Cline, 1970, p. 89-91; Kuenen, 1964, p. 10-13) }\end{array}$} & \multicolumn{3}{|c|}{$\begin{array}{c}\text { Kenwood } \\
\text { Siltstone Member }\end{array}$} \\
\hline & Similar & $\begin{array}{l}\text { Partly } \\
\text { similar }\end{array}$ & $\begin{array}{l}\text { No basis for } \\
\text { comparison }\end{array}$ \\
\hline 1. Alternating fine- and coarse-grained strata & $\bar{x}$ & & \\
\hline $\begin{array}{l}\text { 2. Fine-grained beds are mainly pelagic clay or shale, } \\
\text { lacking evidence of shallow-water deposition }\end{array}$ & $x$ & & \\
\hline 3. Fine-grained beds tend to be uniform & $\hat{x}$ & & \\
\hline $\begin{array}{l}\text { 4. Sediment in the coarse-grained beds tends to be sand } \\
\text { but may be as fine as silt or as coarse as conglom- }\end{array}$ & & & \\
\hline 5. Coarse-grained beds are generally graded, but grading & $x$ & & \\
\hline varies and may be obscure & $x$ & & \\
\hline 6. Lower surfaces of the coarse-grained beds commonly & y & & \\
\hline $\begin{array}{l}\text { 7. The bases of coarse-grained beds are abrupt; the tops } \\
\text { may be somewhat less abrupt or gradational into the } \\
\text { overlying shale }\end{array}$ & 8 & & \\
\hline $\begin{array}{l}\text { 8. The sole marks have directional properties in which } \\
\text { vectoral properties are less common than are } \\
\text { linear }\end{array}$ & 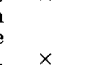 & & \\
\hline $\begin{array}{l}\text { 9. Where several beds are one above the other, the direc- } \\
\text { tional properties tend to be uniform for all the } \\
\text { beds }\end{array}$ & & $x$ & \\
\hline $\begin{array}{l}\text { 10. Internal bedding shows the entire Bouma-sequence } \\
\text { (Bouma, 1962) locally, truncated base or missing }\end{array}$ & 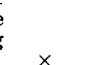 & & \\
\hline $\begin{array}{l}\left.\text { 11. The laminated divisions (Tb or } \mathrm{T}_{d}\right) \text { are common in very } \\
\text { fine sand- and silt-sized beds }\end{array}$ & $y$ & & \\
\hline $\begin{array}{l}\text { 12. Organic trails (trace fossils) may occur on the upper bed } \\
\text { surfaces where gradation occurs and may be missing } \\
\text { where beds are truncated or are immediately overlain } \\
\text { by another turbidite with only a thin or missing shale } \\
\text { interbed }\end{array}$ & 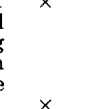 & & \\
\hline 13. Sorting is poor & $\begin{array}{l}x \\
x\end{array}$ & & \\
\hline $\begin{array}{l}\text { 14. Subaerial and shallow-water features such as mud } \\
\text { cracks and algal colonies are absent }\end{array}$ & 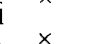 & & \\
\hline 15. Shallow-water fauna are absent except where displaced & & & \\
\hline $\begin{array}{l}\text { and incorporated into the coarse-grained beds } \\
\text { 16. Large-scale crossbedding is absent }\end{array}$ & $x$ & & \\
\hline 17. The thickness of the beds may vary from a few mil- & $\times$ & & \\
\hline $\begin{array}{l}\text { 18. Nearly all deep-sea turbidites are found on slopes of less } \\
\text { than } 1^{\circ}\end{array}$ & 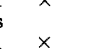 & & \\
\hline $\begin{array}{l}\text { 19. Mud may occur as lumps in beds } \\
\text { 20. The sand or silt may be rich in feldspar, angular quartz, } \\
\text { glauconite, mica, and pyrite }\end{array}$ & $\begin{array}{l}x \\
x\end{array}$ & & \\
\hline $\begin{array}{l}\text { 21. Thinner beds are farther from the dispersal center } \\
\text { 22. Proximal beds show top-truncated Bouma sequences } \\
\text { and fewer fines than do distal beds }\end{array}$ & $\hat{x}$ & & \\
\hline $\begin{array}{l}\text { 23. A lag concentrate of shells, one to two shells thick, is } \\
\text { found locally at the base of the beds }\end{array}$ & & & \\
\hline $\begin{array}{l}\text { 24. Thick stratigraphic sequences have vertical changes in } \\
\text { bedding style resulting from thickness variations in } \\
\text { shale, sandstone, or both }\end{array}$ & 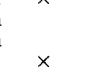 & & \\
\hline $\begin{array}{l}\text { 25. Bed thickness shows a strong correlation with grain size } \\
\text { 26. Plant remains are sparse to abundant }\end{array}$ & & & $\begin{array}{l}x \\
x\end{array}$ \\
\hline
\end{tabular}

geometry and depositional dip, the Kenwood is attributed to the base-of-slope environment similar to that for modern fans (table 6, item 1 ).

The fan shape of the areal distribution, similar to that of modern fans and sediment cones (table 6, item 5 ), is obscured in the Kenwood by the coalescing of two penecontemporaneous fans that make up a single lithostratigraphic unit. Like modern fans (Haner, 1971), the Kenwood tends to thicken towards the apices (fig. 7); cross sections (W-T and M-J, fig. 9) suggest that the paleosurfaces were concave up near the apex and convex up distally. Because the extreme proximal beds of the Kenwood are no longer preserved in the section, the gradient near the apex can no longer be determined; distally, like modern fans, the gradient merges with the basin, as demonstrated by the asymptotic distal approach of the Kenwood to the base of the Borden Formation (fig. 9). The remaining radius of the Kenwood, $10 \mathrm{mi}(15 \mathrm{~km})$, is within the $10-15-\mathrm{km}$ radius characteristic of modern fans.
The greater discrepancy between the Kenwood and the subsea fan model, however, is that the thickness of the turbidite accumulation of the Kenwood is less than $100 \mathrm{ft}(30 \mathrm{~m})$, whereas the total accumulation of turbidite sequences in both the ancient and recent is commonly one or two orders of magnitude greater.

Distribution of the typical Bouma-sequence of internal bedding structures shows little variation in the Kenwood. The sequence $T_{b, e}$ is most abundant. Sequences $T_{b-e}, T_{a-e}$, and $T_{a}$, e are extremely rare or obscure and show little relation to the models proposed by Bouma (1962) and Haner (1971). (See fig. 40.) The presence of channels in the proximal part of the Kenwood is in accord with the fan models of both Walker (1967) and Haner (1971). The nearly complete lack of all but trace fossils in the Kenwood is characteristic of sediment from modern subsea fans.

Revised subsea fan model.-The Kenwood turbidites appear to be a special case of a subsea fan that requires modification of the existing model to fit the particular process-response factors it embodies. Because the lithology and geometry of the Kenwood Siltstone Member is repeated areally and possibly vertically in the Borden in at least three additional units-the Farmers Member ${ }^{1}$, the "Rockcastle freestone" beds of the Wildie Member, and the Lampkins Sandstone Member of the Carwood Formation of Stockdale (1931) in the Indiana outcrops-a modified subsea fan model is proposed to aid in deciphering the details of their paleogeographic setting.

The "thin" subsea-fan model proposed here for the Kenwood was built from a dispersal center that was short-lived geologically. This negates persistent episodic fault movement. The thin-fan model in itself lacks indications of distance from the shore or depth of the water. Creation of a fan-shaped body would require a dispersal point such as a distributary channel down which sediment was introduced to the shelf floor and down which the turbidity currents came episodically. Indications of distance from the shore and some measure of depth may be gained by examining the stratigraphic relations in reference to the vertical profile (Visher, 1965).

\section{TRIGGERING MECHANISM OF THE TURBIDITY CURRENTS}

The turbidity currents of the Kenwood Siltstone Member of the Borden Formation appear to have been triggered by mechanisms of a wide range of intensity, because the beds range in thickness from less than 0.1

${ }^{1}$ Moore and Clarke $(1970$, p. 213$)$ confirmed the suggested turbidite nature of the Farmers (Kepferle, 1968b) and delineated a westward-facing paleoslope in water ranging in possible depth from 675 to less than $100 \mathrm{ft}(206-30.5 \mathrm{~m})$ on the basis of earlier estimates of the environment of deposition proposed for the Chattanooga-Ohio-New Albany Shale below the Borden. 
TABLE 5.-Comparison of proximal and distal turbidites, Kenwood Siltstone Member of the Borden Formation [Listed in the order of Walker (1967, table 2)]

Proximal

Distal

A. Beds thick, as much as $20 \mathrm{ft}$ $(6 \mathrm{~m})$.

B. Beds of mainly silt grains --

C. Individual beds amalgamated.

D. Beds irregular in thickness.-

E. One washout, five channels --

F. Mudstone partings thin, occasionally poorly developed or absent; siltstone:shale ratio high.

G. Beds content graded

H. Base of siltstone always sharp; top often sharp; rare $\mathrm{T}_{\mathrm{a}-\mathrm{e}}$ sequences.

1. Laminations common; ripples rare.

J. Scour marks present; tool marks common.

Beds thin, one exception.

Beds of mainly silt grains.

Individual beds not amalgamated.

Beds fairly uniform in thickness.

No washouts, no channels.

Shale partings well developed; siltstone:shale ratio low.

Beds content graded.

Base of siltstone always sharp; top often sharp; $\mathrm{T}_{\mathrm{a}-\mathrm{e}}$ sequences absent.

Laminations common; ripples absent.

Scour marks absent; tool marks less common.

$\mathrm{ft}$ to $20 \mathrm{ft}$ ( $3 \mathrm{~cm}$ to $6 \mathrm{~m}$ ). Similar ranges in the thickness of the shaly beds indicate intervals between generative incidents estimated to range from a few years to several thousand years. Of the mechanisms listed on table 7 , seismic shock seems most in accord with the evidence from the Kenwood turbidites.

\section{FACIES ANALYSIS AND THE VERTICAL PROFILE}

Information necessary to recognize sedimentary sequences in a vertical profile has been described by Visher (1965) as three types: (1) physical sedimentary aspects in terms of bedding, grain size, sorting, and sedimentary structures, (2) biologic aspects in terms of paleoecology, and (3) presence and significance of sedimentary breaks. For the sake of interpretation, I have considered the entire Borden Formation as well as the underlying New Albany Shale and the overlying Harrodsburg Limestone within the study area. The columnar section of this sequence of rocks, plus the vertical profile in terms of the three types of information listed above, is shown in figure 41. Also shown is my interpretation of the environmental significance of this information relative to the vertical profile.

\section{ENVIRONMENTS OF DEPOSITION}

The depositional environments of the Borden Formation can be characterized morphologically in order of decreasing depth of water as (1) basin-floor, (2) baseof-slope, (3) slope, and (4) platform. As a group, these environments have been assigned depositionally to a deltaic environment (Rich, 1951a; Swann and others, 1965; Peterson and Kepferle, 1970). I am using the expanded definition of the term "delta" as proposed by Moore and Asquith (1971, p. 2566): "The subaerial and submerged contiguous sediment mass deposited in a
TABLE 6.-Characteristics of modern and ancient subsea fans relative to the Kenwood Siltstone Member of the Borden Formation

\begin{tabular}{|c|c|c|c|}
\hline \multirow{2}{*}{$\begin{array}{l}\text { Characteristic of modern and ancient fans } \\
\text { (Compiled from Haner, 1971; Sullwold, 1960, 1961; } \\
\text { Walker, 1967; others cited in text) }\end{array}$} & \multicolumn{3}{|c|}{ Similarity to Kenwood } \\
\hline & Yes & No & Uncertain \\
\hline \multicolumn{4}{|l|}{ Location: } \\
\hline 1. Base of slope & $x$ & & \\
\hline 2. Common at mouth of submarine canyon - & & & $x$ \\
\hline 3. Large where canyon heads near shore & & & $x$ \\
\hline 4. Small where canyon heads far from shore & & & $x$ \\
\hline \multicolumn{4}{|l|}{ Geometry: } \\
\hline 5. Fan shaped & $x$ ? & & \\
\hline 6. Thickest near apex & $\times$ & & \\
\hline 7. Surface concave up near apex & $\times ?$ & & \\
\hline Surface convex up distally & $\times ?$ & & \\
\hline 8. Gradient $3^{\circ}$ near apex & $\times ?$ & & \\
\hline Gradient merges with basin distally & $x$ & & \\
\hline 9. Radius $10-15 \mathrm{~km}$ & $x$ & & \\
\hline 10. Thickness ranges into thousands of feet $\left(1-3 \times 10^{3} \mathrm{~m}\right)$ & & $x$ & \\
\hline \multicolumn{4}{|l|}{ Sedimentary structures, fabric, and fossils: } \\
\hline 11. Sedimentary structures vary with location & $x$ & & \\
\hline 12. Current structures in pattern radiating from apex & $\ddot{x}$ & & \\
\hline 13. Channels present, more numerous proximally & $x$ & & \\
\hline 14. Channels tend to radiate from apex & $x$ & & \\
\hline 15. Definite downslope decrease in grain size & & $x$ & \\
\hline 16. Benthonic fauna rare or absent with exception of & & & \\
\hline & $x$ & & \\
\hline
\end{tabular}

body of water (ocean or lake) primarily by the action of a river."

A deltaic sequence is well suited to facies analysis. The sedimentary facies and breaks in sedimentation involved in the vertical profile study of the Borden are listed with the anticipation that an environment of deposition can be proposed for each. A black-shale facies is represented by the pre-Borden New Albany Shale. The first of two hiatuses in sedimentation is represented by the zone of phosphate nodules at the base of the Mississippian sequence. Four terrigenous lithologic facies are recognizable in the clastic part of the Borden, above which the second major break in sedimentation is identified by a bioturbated glauconitic surface, followed in turn by two carbonate rock facies.

\section{BASIN-FLOOR ENVIRONMENT}

The black-shale facies typifies the early phase of the basin-floor environment. It covers a wide area and forms the base for the ensuing greenish-gray shale and siltstone which spread over it from the east during the Early Mississippian. The black-shale environment is mainly anaerobic, implying poor circulation; this assessment is supported by the clay- to silt-sized constituent particles, which apparently accumulated at a slow rate. Conant and Swanson (1961, p. 54-55) suggested an accumulation rate of about $5 \mathrm{~cm} / 1,000$ years.

If the depth of water in which the black-shale facies accumulated were known, it could furnish a strong basis for interpreting the environment of deposition of the overlying Mississippian green shales. Recent workers have suggested that the euxinic environment in which these black shales like the New Albany accumulated may have been in deep water (Rich, 1951b p. 2038-2039), shallow water (Pepper and others, 1954, p. 97; Conant and Swanson, 1961, p. 60-62), or of var- 
A

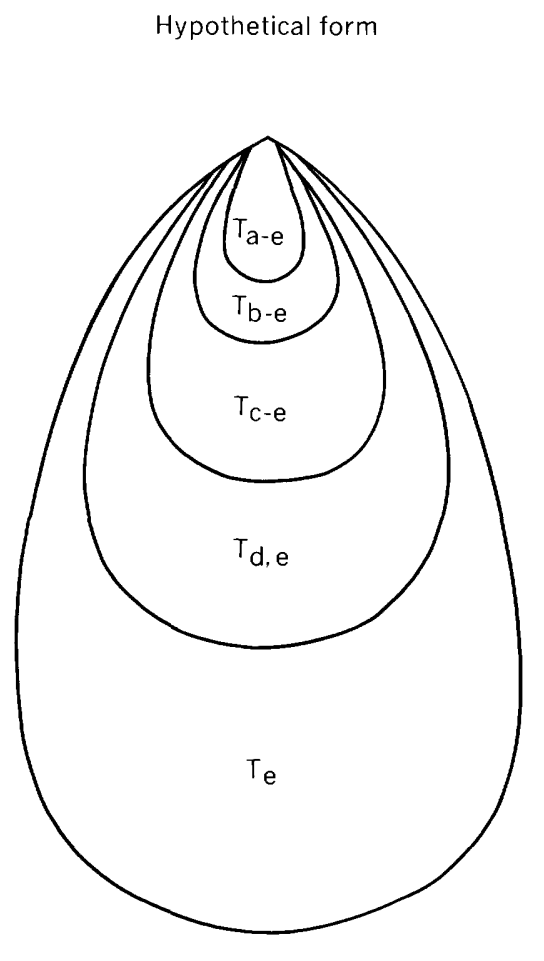

From Bouma (1962, fig. 25A)
B

Segmented fan sequence

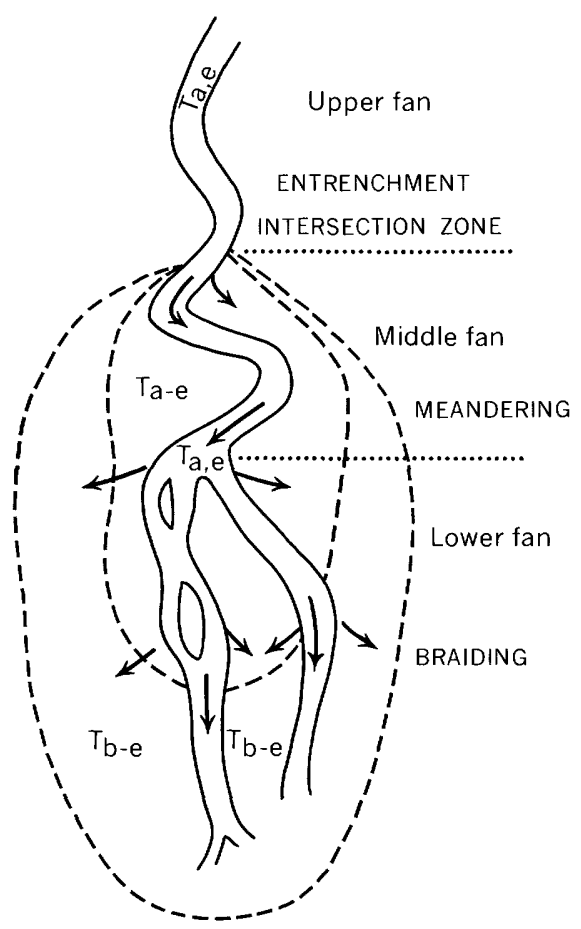

From Haner (1971, fig. 15)

FIGURE 40.-Diagrams showing variation of internal bedding sequence in turbidites according to position on subsea fan.

ied depths (Lineback, 1968b, p. 1303). James (1971) indicated that deeper water may be a more prevalent deposition environment for black shale than is shallow water, proposing that the anoxic-water system results from the development of a widespread density gradient which inhibits circulation of bottom water. The absolute depth of the basin in which the black shale was deposited remains unknown. An upward decrease in gray-shale beds and a widespread basal thin sand interpreted as a transgressive sheet sand suggest to me that the Devonian black shale was deposited in an environment that was gradually increasing in depth through time and possibly ranged from circalittoral to infralittoral.

The thin zone of phosphate nodules overlying the black shale in the study area and included in the basal New Providence Shale Member represents a depositional hiatus in most of the Kentucky part of the study area. The entire Kinderhookian interval is attributed to this phosphatic zone and the several inches of green shale and discontinuous Rockford Limestone above it (Lineback, 1968b, fig. 7; Conant and Swanson, 1961, p. 67). Thus, deposition on the basin floor appears to have been minimal in earliest Mississippian time, and the zone of phosphate nodules on the black shale appears to have been synchronous. The regularity and continuity of this zone indicate that it was not swept by strong currents. (See fig. 42 , block $T_{1}$.)

Deposition on the basin floor resumed in a somewhat more aerated environment. Dominantly green clayey sediment prevailing throughout most of the study area indicates pelagic deposition from a distant terrigenous source. The thickening of the clayey sediment in an easterly direction in the study area indicates that this

TABLE 7.-Triggering mechanisms of turbidity currents, Kenwood Siltstone Member of the Borden Formation

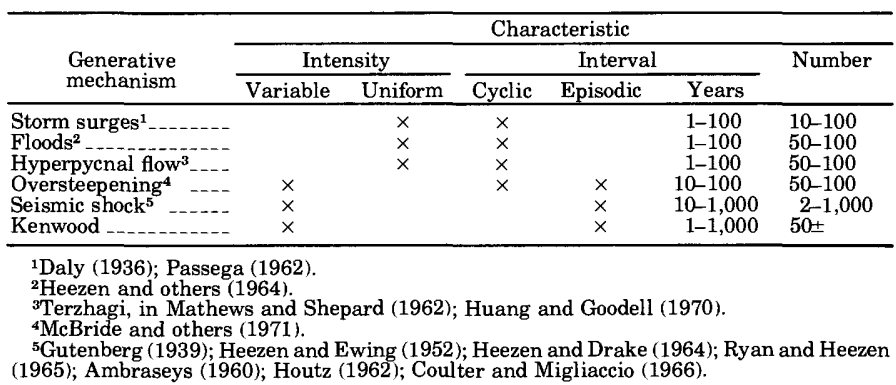



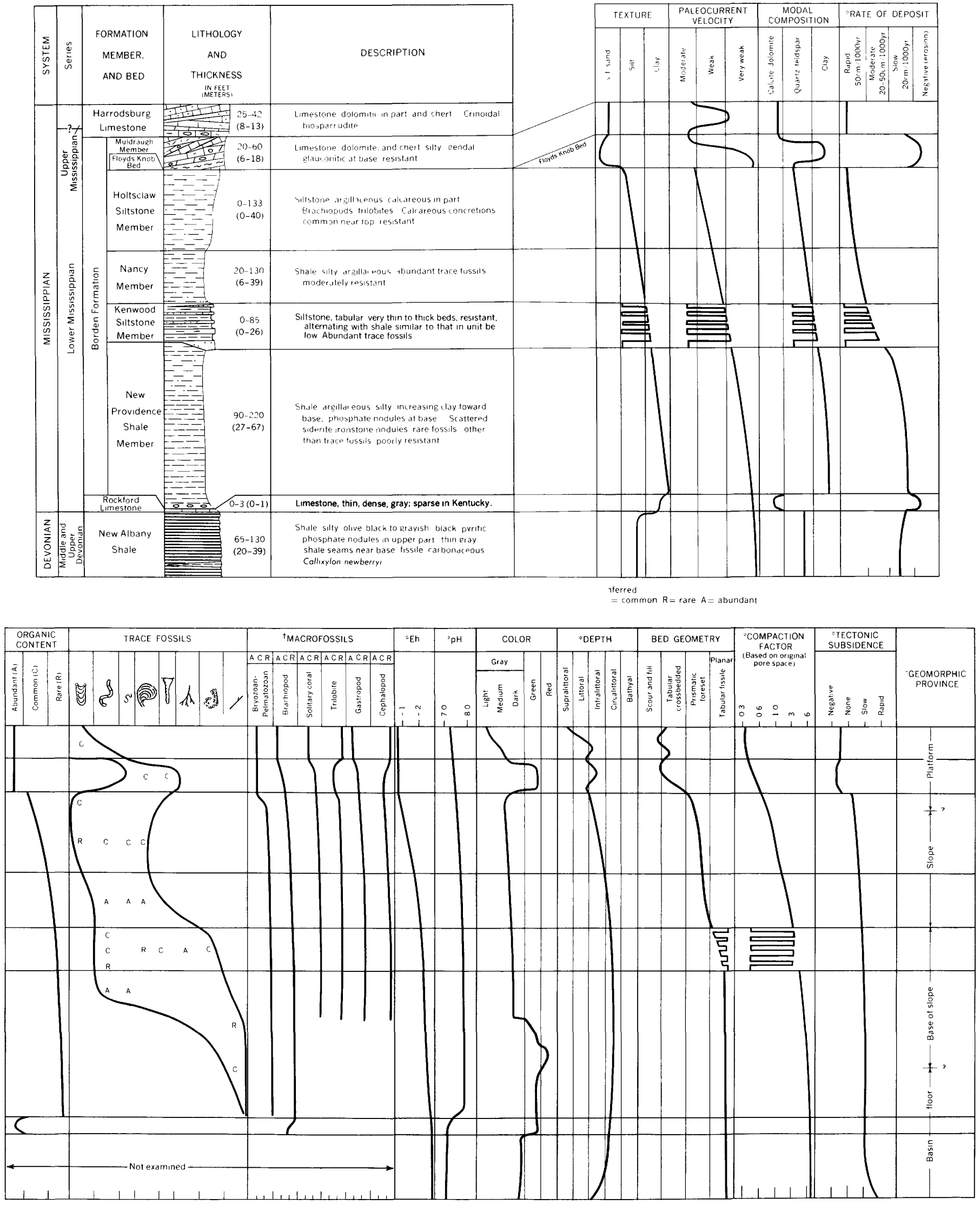

Figure 41.-Vertical profile and facies analysis of the Borden Formation, north-central Kentucky. 


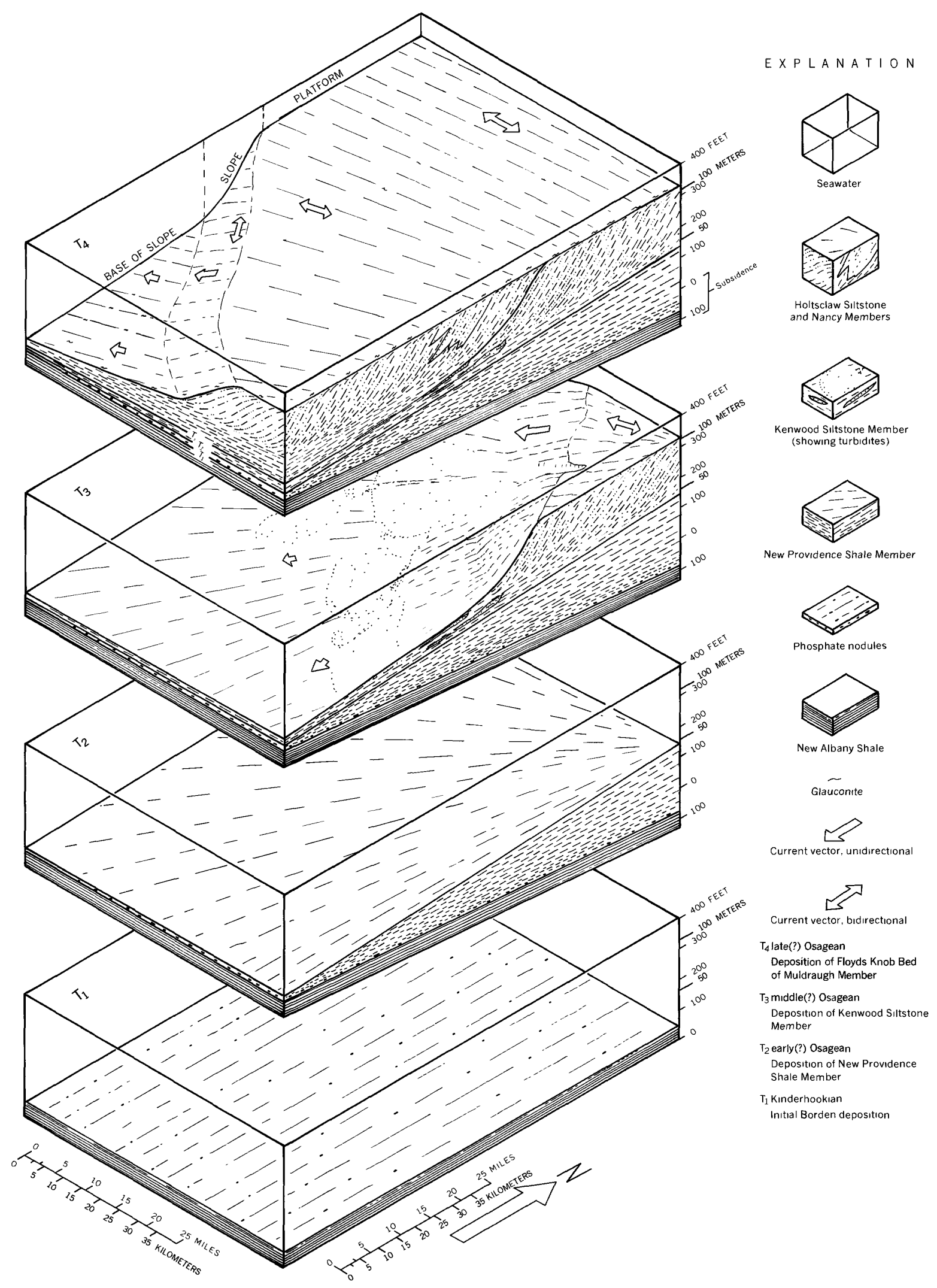

Frgure 42.-Sequential block diagrams showing depositional environments of the Borden Formation. 
source was to the east (Peterson and Kepferle, 1970, fig. 4C).

The characteristics of the basin-floor environment after the accumulation of the phosphate nodules were: 1. Beds essentially flat lying; surface sloping slightly to the west at less than $10 \mathrm{ft} / \mathrm{mi}(1.9 \mathrm{~m} / \mathrm{km})$.

2. No significant bottom current.

3. Epifauna and infauna sparse.

4. Low oxygenation, as shown by local siderite, glauconite, and phosphate indicative of $\mathrm{Eh}$ from 0 to $-0.25, \mathrm{pH}$ from 7.0 to $7.8 \pm$ (Krumbein and Garrels, 1952, fig. 8).

5. Widespread muddy bottom from pelagic sediment.

6. Depth greater than $265 \mathrm{ft}(81 \mathrm{~m})$.

\section{BASE-OF-SLOPE ENVIRONMENT}

The upper silty clay shale of the New Providence Shale Member and the flat-lying tabular siltstone and channel-fill siltstone beds of the Kenwood Siltstone Member were deposited on a virtually flat basin floor at the base of a slope leading upward to a prograding deltaic or paralic platform (fig. 42 , block $\mathrm{T}_{2}$ ). The shale of the New Providence becomes increasingly silty, changes from green to gray, and contains increasingly abundant trace fossils upwards. These fossils are mainly of the small boring types; possible sticklike plant remains less than $1 \mathrm{~mm}$ thick are more common near the base of the sequence. Because deposition was somewhat more rapid near the base of the slope, the surface was somewhat steeper here than farther out on the basin floor. From these generalities and from details discussed earlier in the paper concerning the New Providence and the Kenwood, the characteristics for the base-of-slope environment for the Borden in the study area were:

1. Beds virtually flat lying; surface sloping to the west at $10-25 \mathrm{ft} / \mathrm{mi}(1.9-4.7 \mathrm{~m} / \mathrm{km})$.

2. Relatively low-energy gravity-driven density currents from a slope that faced west; currents were episodic, debouching from at least two minor canyons (fig. 42 , block $\mathrm{T}_{3}$ ).

3. Benthonic infauna expressed as trace fossils relatively abundant.

4. Low oxygenation; $\mathrm{Eh}$ from 0 to $-0.25 ; \mathrm{pH}$ from 7.0 to $7.8 \pm$, similar to that in basin-floor environment.

5. Bottom muddy with increasing amount of silt.

6. Depth shallows from the basin floor by $\pm 100 \mathrm{ft}$ $( \pm 30 \mathrm{~m})$.

\section{SLOPE ENVIRONMENT}

The rocks above the dominantly clay shale of the New Providence were deposited in the slope environment. The siltstone and silty shale of this environment, the Nancy and Holtsclaw Siltstone Members, show obscurely ripple-laminated bedding that is disturbed by bioturbation in increasing amounts upwards. Scattered invertebrate remains also become increasingly abundant upwards in the rock sequence and include brachiopods, bryozoans, gastropods, trilobites, and scattered banks of crinoidal limestone. In the sediment immediately overlying the Kenwood, fall-off (depositional dip) to the west is shown in the coarser and more resistant massive siltstone of the Holtsclaw (Kepferle, 1971, 1972a, b).

The magnitude of the slope environment is evident in the relief of the contact between the Muldraugh Member and the underlying units of the Borden Formation along the Borden delta front (Peterson and Kepferle, 1970, fig. 4B), less than $10 \mathrm{mi}(16 \mathrm{~km})$ west of the west edge of the Kenwood. This contact is marked in Kentucky by the Floyds Knob Bed, a bored surface and glauconitic deposit, which I interpret to represent a hiatus in sedimentation. It shows the form of the sea floor at the time building of the delta front ceased and probably is characteristic of the topography during the deposition of the clastic unit (fig. 42 , block $T_{4}$ ). No marked lithologic changes take place in the preMuldraugh Borden between the Borden delta front and the Kenwood outcrops, indicating that depositional environments were about the same over this broad area. Hence, the slopes down which the turbidity currents flowed to introduce the siltstone of the Kenwood to the base-of-slope environment were about the same as the slope of the front marked by the Floyds Knob Bed. Relief on the front is about $200 \mathrm{ft}(61 \mathrm{~m})$ over distances ranging from 4 to $8 \mathrm{mi}(6.4-12.8 \mathrm{~km})$. The slope ranges from about 25 to $50 \mathrm{ft} / \mathrm{mi}(4.7-9.4 \mathrm{~m} / \mathrm{km})$ over the entire distance. Locally the slope is as much as $120 \mathrm{ft} / \mathrm{mi}$ $\left(22.7 \mathrm{~m} / \mathrm{km}\right.$ )-slightly more than $1^{\circ}$ (Peterson and Kepferle, 1970, fig. 4B). Similar slopes are common on modern deltas (Fisk, 1961; Mathews and Shepard, 1962; Allen, 1970).

Compaction may have modified slightly the original relief on the depositional front. On the basis of studies of the Fraser River delta, Mathews and Shepard (1962) indicated that muds tend to undergo compaction and lose 50 percent of their original volume and that most of this takes place within 2,000 years of deposition. Accumulation on major deltaic cones ranges from 10 to $30 \mathrm{~cm} / 1,000$ years (Ewing and others, 1958; Huang and Goodell, 1970; Stanley and Huang, 1971). Thirty $\mathrm{cm} / 1,000$ years is estimated as an average rate of accumulation for the Borden clastic rocks. At this rate, only the top meter of sediment would be relatively uncompacted in the Borden. The remaining postdepositional compaction would be small and would have little effect on the relief of the front. In other words, the slope preserved in the geologic record is virtually the slope present during the deposition of the Kenwood. Con- 
straints one must consider are penecontemporaneous and postdepositional basinal subsidence, both of which are accounted for in the cross sections in figure 9 and the block diagrams in figure 42 .

The characteristics of the slope environment in the study area are:

1. Surface slopes range from $25 \mathrm{ft} / \mathrm{mi}$ to more than 120 $\mathrm{ft} / \mathrm{mi}(4.7-22.7 \mathrm{~m} / \mathrm{km})$ over a distance of $4-8 \mathrm{mi}$ $(6.4-12.8 \mathrm{~km})$.

2. Local small canyons carried turbidity currents of moderate energy; upper part of slope swept by low-energy surface-generated currents.

3. Epifauna and infauna increase in abundance upwards.

4. Somewhat higher oxygenation than at base of slope; Eh from 0 to $-0.25, \mathrm{pH}$ from 7.5 to $8.5 \pm$.

5. Widespread muddy substrate, increasingly silty near top.

6. Depth of water infralittoral (below tidal zone to 150 $\mathrm{ft}(46 \mathrm{~m}))$ to circalittoral $(150-600 \mathrm{ft}(46-182 \mathrm{~m}))$ (Krumbein and Sloss, 1963, p. 259).

\section{PLATFORM ENVIRONMENT}

In pre-Muldraugh deposition, no sediment accumulated on the platform except, perhaps, the uppermost few feet of the Holtsclaw Siltstone Member of the Borden Formation, or, where the Holtsclaw is absent, the Nancy Member. The sediment of these few feet is mainly siltstone or clayey silt shale containing abundant brachiopods, bryozoans, gastropods, trilobites, and scattered banks of crinoidal limestone, and trace fossils. Original ripple lamination is obscured by bioturbation. Trace fossils are more abundant in the clayey shale. Most of the platform may have been swept by surface storm and tidal currents.

The characteristics of the Borden delta platform in the study area were:

1. Beds virtually flat; surface sloping to the west only slightly if at all.

2. Surface currents from waves and tides moderate to low energy.

3. Epifauna relatively abundant.

4. Eh -0.1 to $-0.2, \mathrm{pH} 7.8 \pm$; lack of limestoneproducing organisms attributed to turbid water.

5. Bottom mainly silty mud.

6. Depth below tide level in upper infralittoral zone $(24-60 \mathrm{ft}(7-18 \mathrm{~m}))$.

\section{EROSIONAL PHASE AND DEPOSITIONAL HIATUS}

The erosional phase is represented by the Floyds Knob Bed of the Muldraugh Member. The bed is persistent, is as much as $15 \mathrm{ft}(4.6 \mathrm{~m})$ thick, and contains at least one and in many places two layers in which glauconite is concentrated. Sparsely distributed oolitic limestone and local thin beds showing bimodal crossbedding (Kepferle, 1972a) possibly represent a shoaling environment within the tidal zone. Glauconite-filled burrows in the surface of the underlying slope deposits indicate a hiatus in sedimentation on this surface. The hiatus probably represents a shift in the dispersal pattern of the terrigenous clastic materials, followed by marine transgression over the platform, resulting in some erosion of the platform sediment in Kentucky. (See fig. 42, block $\mathrm{T}_{4}$.)

\section{CARBONATE PLATFORM ENVIRONMENT}

An infralittoral origin (20-150 ft, or 6-46 m) for the sediment of the Muldraugh Member of the Borden is suggested by a dominance of calcite and dolomite silt, by the inferred abundance of anhydrite and gypsum as precursors of quartz geodes (Chowns and Elkins, 1971, 1974), and by the bryozoan-crinoid-brachiopod invertebrate fauna. The increase in locally derived carbonate in the Muldraugh corresponds with a decrease in terrigenous detritus reaching this part of the sedimentary platform. Initial dip to the southwest in some of the associated limestone and sandstone bodies (Sedimentation Seminar, 1972) indicates that this infralittoral environment was swept intermittently by westward-flowing currents that winnowed crinoidal communities and redeposited the debris as banks on the foreset slopes of the platform edge. Eventually this thin layer of carbonates prograded westward to the edge of the terrigenous sediment platform on which deposition had virtually ceased. That this westward advance was far more complicated than I have stated is brought out by recent studies of the Edwardsville Member of the Muldraugh Formation of Indiana usage (Lane, 1973; Whitehead, 1973, 1976) and by the poorly understood relation of the Muldraugh Member and the Nada and Renfro Members of the Borden in eastcentral Kentucky (Weir and others, 1966, Weir, 1970).

\section{THE PALEOSLOPE AND PALEOTECTONICS}

A west-southwest paleoslope during the deposition of the Kenwood Siltstone Member of the Borden Formation is indicated by:

1. The southwest stratigraphic descent of the Kenwood Siltstone Member within the Borden.

2. The southwest imbrication of the individual siltstone beds in the Kenwood.

3. The west-southwest direction of sole marks and other paleocurrent indicators within the Kenwood, which indicate deposition from downslope currents.

4. Analogy with the west-southwest slope of the Borden delta front, as revealed by the configuration of the Floyds Knob Bed.

Orientation and migration of the paleoslope.-The strike of the paleoslope during Kenwood deposition 
paralleled closely the depositional strike of the Kenwood. By the end of terrigenous clastic deposition in the Borden of this area, the strike of the paleoslope swung slightly west of the depositional strike (fig. 5). A comparison of the paleocurrents for the Kenwood with those of the Farmers Member of the Borden in northeastern Kentucky indicates that the paleocurrent system was virtually constant (fig. 39). Because of similarity in inferred paleocurrents and petrology of the Kenwood and the Farmers, a current-deflecting deep-weathering lowland along the axis of the Cincinnati arch as postulated by Pepper, de Witt, and Demarest (1954, pl. 13) for Early Mississippian (Kinderhookian) time could not have been emergent during deposition of these siltstone bodies.

Paleotectonics.-The implication of this westward persistence of paleoslope is that the tectonic setting of the Eastern Interior and Appalachian basins in the Late Devonian continued into Early Mississippian time. The final stages of the Acadian orogeny in and east of New England fostered the maximum westward advance of the Pocono alluvial wedge (Meckel, 1970, p. 54). A comparison with studies of Early Mississippian paleocurrents and paleotectonics of the Appalachian basin indicates that the terrigenous clastic materials of the Borden constitute the distal marine edge of this westward-prograding terrigenous clastic wedge. Dwindling paroxysms of minor strain release, perhaps far to the east, initiated slope failure and turbidity currents along the front of the active distributary channels of the major streams. Two such channels on the delta front in central Kentucky were the dispersal centers for the turbidites of the Kenwood Siltstone Member. (See fig. 43.)
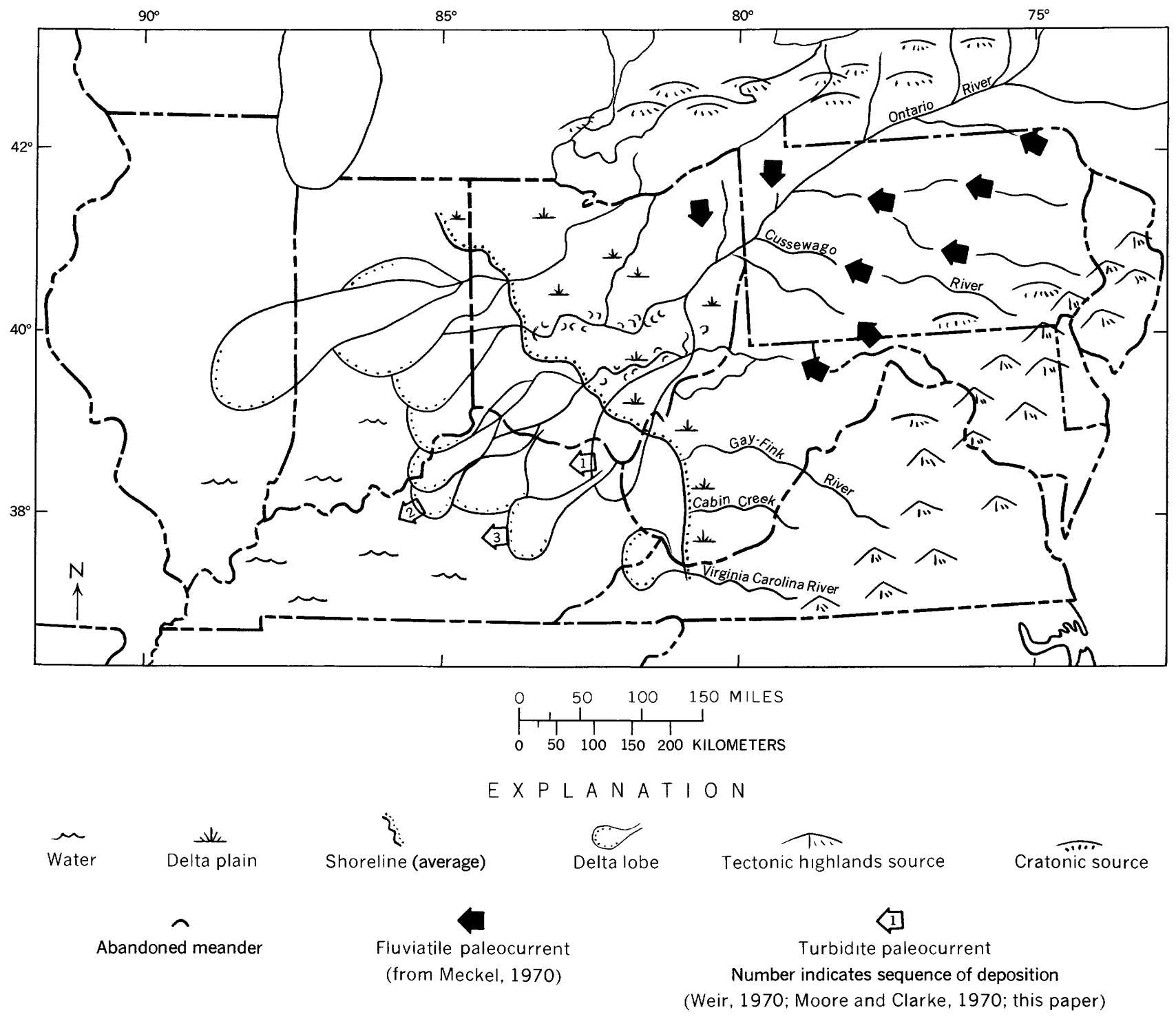

Figure 43.-Paleogeographic diagram of eastern interior during deposition of Kenwood Siltstone Member and related Lower Mississippian rocks prior to final establishment of Borden delta front, showing composite of paleocurrents. (River names from Pepper and others, 1954.) 


\section{REFERENCES CITED}

Allen, J. R. L., 1970, Sediments of the modern Niger delta: a summary and review, in Morgan, J. P., and Shaver, R. H., eds., Deltaic sedimentation, modern and ancient: Soc. Econ. Paleontologists and Mineralogists Spec. Pub. 15, p. 138-151.

Ambraseys, N. N., 1960, The seismic sea wave of July 9, 1956, in the Greek Archipelago: Jour. Geophys. Research, v. 65, no. 4, p. 1257-1265.

Bartlett, C. S., Jr., 1974, Anatomy of the Lower Mississippian delta in southwestern Virginia: Knoxville, Tenn., Univ. Tennessee, unpub. thesis, $372 \mathrm{p}$

Bates, C. C., 1953, Rational theory of delta formation: Am. Assoc. Petroleum Geologists Bull., v. 37, no. 9, p. 2119-2162.

Beall, A. O., Jr., 1970, Turbidites of the Gulf of Mexico abyssal plain [abs.]: Geol. Soc. America Abs. with Programs, v. 2, no. 7, p. 490.

Bouma, A. H., 1962, Sedimentology of some flysch deposits; a graphic approach to facies interpretation: Amsterdam, Elsevier, $168 \mathrm{p}$.

Bouma, A. H., and Shepard, F. P., 1964, Large rectangular cores from submarine canyons and fan valleys: Am. Assoc. Petroleum Geologists Bull., v. 48, no. 2, p. 225-231.

Butts, Charles, 1915, Geology and mineral resources of Jefferson County, Kentucky: Kentucky Geol. Survey, ser. 4, v. 3, pt. 2, $270 \mathrm{p}$.

1922, The Mississippian series of eastern Kentucky: Kentucky Geol. Survey, ser. 6, v. 7, 188 p.

Chowns, T. M., and Elkins, J. E., 1971, Origin of geodes from the Fort Payne Formation, Woodbury, Tennessee [abs.]: Geol. Soc. America Abs. with Programs, v. 3, no. 5, p. 303.

1974, The origin of quartz geodes and cauliflower cherts through the silicification of anhydrite nodules: Jour. Sed. Petrology, v. 44 , no. 3, p. 885-903.

Clarke, M. K., 1969, The Farmers Siltstone: a flysch-like deposit in northeastern Kentucky: Lexington, Ky. Univ. Kentucky, unpub. M. S. thesis, $69 \mathrm{p}$.

Cline, L. M., 1970, Sedimentary features of late Paleozoic flysch, Ouachita Mountains, Oklahoma, in Lajoie, J., ed., Flysch sedimentology in North America: Geol. Assoc. Canada, Spec. Paper 7, p. 85-101.

Conant, L. C., and Swanson, V. E., 1961, Chattanooga Shale and related rocks of central Tennessee and nearby areas: U.S. Geol. Survey Prof. Paper 357, 91 p.

Conkin, J. E., 1954, Hyperammina kentuckyensis n. sp. from the Mississippian of Kentucky, and discussion of Hyperammina and Hyperamminoides: Cushman Found. Foram. Research Contr., v. 5 , pt. 4 , p. $165-169$.

1956, Hyalostelia ancora Gutschick in the Mississippian of Indiana and Kentucky: Am. Midland Naturalist, v. 56, no. 2, p. $430-433$.

1957, Stratigraphy of the New Providence Formation (Mississippian) in Jefferson and Bullitt Counties, Kentucky, and fauna of the Coral Ridge Member: Bulls. Am. Paleontology, v. 38, no. 168 , p. 109-157.

1960, Mississippian smaller Foraminifera of southern Indiana, Kentucky, northern Tennessee, and south-central Ohio: Cincinnati, Univ. Cincinnati, unpub. Ph. D. thesis, 413 p.

Conkin, J. E., and Conkin, B. M., 1968, Scalarituba missouriensis and its stratigraphic distribution: Kansas Univ. Paleont. Contr., Paper 31, $7 \mathrm{p}$.

1972, Guide to the rocks and fossils of Jefferson County, Kentucky, southern Indiana, and adjacent areas: Lousiville, Ky., Univ. Louisville Printing Services, 331, p., 51 pl.

Coulter, H. W., and Migliaccio, R. R., 1966, Effects of the earthquake of March 27, 1964, at Valdez, Alaska: U.S. Geol. Survey Prof. Paper 542-C, $36 \mathrm{p}$.

Daly, R. A., 1936, Origin of submarine canyons: Am. Jour. Sci., 5th ser., v. 31 , no. 186 , p. $401-420$.
Dunbar, C. O., and Rogers, John, 1957, Principles of stratigraphy: New York, John Wiley and Sons, $356 \mathrm{p}$.

Dzulynski, Stanislaw, and Simpson, Frank, 1966, Experiments on interfacial current markings: Geologica Romana, v. 5, p. $197-214$.

Englund, K. J., 1968, geology and coal resources of the Elk Valley area, Tennessee and Kentucky: U.S. Geol. Survey Prof. Paper $572,59 \mathrm{p}$.

Ericson, D. B., Ewing, Maurice, and Heezen, B. C., 1952, Turbidity currents and sediments in North Atlantic: Am. Assoc. Petroleum Geologists Bull., v. 36, no. 3, p. 489-511.

Ewing, Maurice, Ericson, D. B., and Heezen, B. C., 1958, Sediments and topography of the Gulf of Mexico, in Weeks, L. G., ed., Habitat of oil-a symposium: Tulsa, Am. Assoc. Petroleum Geologists, p. 995-1053.

Fisk, H. N., 1961, Bar-finger sands of Mississippi delta, in Peterson, J. A., and Osmond, J. C., eds., Geometry of sandstone bodies-a symposium, 45th Ann. Mtg., Atlantic City, N.J., 1960: Tulsa, Am. Assoc. Petroleum Geologists, p. 29-52.

Folk, R. L., 1954, The distinction between grain size and mineral composition in sedimentary-rock nomenclature: Jour. Geology, v. 62 , no. 4 , p. $344-359$.

1968, Petrology of sedimentary rocks: Austin, Tex., Hemphill's, $170 \mathrm{p}$.

Gorsline, D. S., and Emery, K. O., 1959, Turbidity-current deposits in San Pedro and Santa Monica basins off southern California: Geol. Soc. America Bull., v. 70, no. 3, p. 279-290.

Gutenberg, Beno, 1939, Tsunamis and earthquakes: Seismol. Soc. America Bull., v. 29, no. 4, p. 517-526.

Gutschick, R. C., 1954, Sponge spicules from the Lower Mississippian of Indiana and Kentucky: Am. Midland Naturalist, v. 52, no. 2, p. 501-509.

Haner, B. E., 1971, Morphology and sediments of Redondo submarine fan, southern California: Geol. Soc. America Bull., v. 82, no. 9, p. 2413-2432.

Häntzschel, Walter, 1962, Trace fossils and Problematica, in Moore R. C., ed., Treatise on invertebrate paleontology-Pt. W, Miscellanea: New York, Geol. Soc. America (and Univ. Kansas Press) p. W177-W245.

Harms, J. C., and Fahnestock, R. K., 1965, Stratification, bed forms, and flow phenomena (with an example from the Rio Grande), in Middleton, G. V., ed., Primary sedimentary structures and their hydrodynamic interpretation-a symposium: Soc. Econ. Paleontologists and Mineralogists Spec. Pub. 12, p. 84-115.

Harrison, J. E., and Grimes, D. J., 1970, Mineralogy and geochemistry of some Belt rocks, Montana and Idaho: U.S. Geol. Survey Bull. 1312-O, 49 p.

Hasson, K. O., 1972, Lithostratigraphy of the Grainger Formation (Mississippian) in northeast Tennessee: Knoxville, Tenn., Univ. Tennessee, unpub. thesis, $170 \mathrm{p}$.

Heezen, B. C., and Drake, C. L., 1964, Grand Banks slump: Am. Assoc. Petroleum Geologists Bull., v. 48, no. 2, p. 221-225.

Heezen, B. C. and Ewing, Maurice, 1952, Turbidity currents and submarine slumps, and the 1929 Grand Banks earthquake: Am. Jour. Sci., v. 250 , no. 12 , p. $849,873$.

Heezen, B. C., and others, 1964, Congo submarine canyon: Am. Assoc. Petroleum Geologists Bull., v. 48, no. 7, p. 1126-1149.

Hjulstrom, Filip, 1939, Transportation of detritus by moving water, in Trask, P. D., ed., Recent marine sediments: Tulsa, Okla., Am. Assoc. Petroleum Geologists, p. 5-51 (Reprinted in: Soc. Econ. Paleontologists and Mineralogists Spec. Pub. 4, 1955).

Houtz, R. E., 1962, The 1953 Suva earthquake and tsunami: Seismol. Soc. America Bull., v. 52, no. 1, p. 1-12.

Hrabar, S. V., Kepferle, R. C., Klekamp, C. T., Pryor, W. A., and Potter, P. E., 1971, Knifley sandstone: early Mississippian infralittoral sandstone body [abs.]: Am. Assoc. Petroleum Geologists Bull., v. 55, no. 2, p. 344-345. 
Huang, Ter-Chien, and Goodell, H. G., 1970, Sediments and sedimentary processes of eastern Mississippi cone, Gulf of Mexico: Am. Assoc. Petroleum Geologists Bull., v. 54, no. 11, p. $2070-2100$.

James, G. W., 1971, Depositional environment of widespread Pennsylvanian black shale (Excello) [abs.]: Am. Assoc. Petroleum Geologists Bull., v. 55, no. 2, p. 345 .

Kearby, J. K., 1971, The Cowbell Member of the Borden Formation (Lower Mississippian) of northeastern Kentucky; a delta front deposit: Lexington, Ky., Univ. Kentucky, unpub. M. S. thesis, $89 \mathrm{p}$.

Kepferle, R. C., 1968a, Geologic map of the Shepherdsville quadrangle, Bullitt County, Kentucky: U.S. Geol. Survey Geol. Quad. Map GQ-740, scale 1:24,000.

1968b, Turbidites in the Lower Mississippian Borden Formation of central Kentucky [abs.]: Geol. Soc. America Spec. Paper 115 , p. 390-391.

1969, Geologic map of the Samuels quadrangle, north-central Kentucky: U.S. Geol. Survey Geol. Quad. Map GQ-824, scale 1:24,000.

1971, Members of the Borden Formation (Mississippian) in north-central Kentucky: U.S. Geol. Survey Bull. 1354-B, 18 p.

1972a, Geologic map of the Valley Station quadrangle and part of the Kosmosdale quadrangle, north-central Kentucky: U.S. Geol. Survey Geol. Quad. Map GQ-962, scale 1:24,000.

1972b, Geologic map of the Brooks quadrangle, Bullitt and Jefferson Counties, Ky.: U.S. Geol. Survey Geol. Quad. Map GQ-961, scale 1:24,000.

1972c, Stratigraphy, petrology, and depositional environment of the Kenwood Siltstone Member, Borden Formation (Mississippian), Kentucky and Indiana: U.S. Geol. Survey open-file report and Cincinnati, Ohio, Univ. Cincinnati, unpub. Ph.D. thesis, 233 p., 12 pls., 42 figs.

-1974, Geologic map of parts of the Louisville West and Lanesville quadrangles, Jefferson County, Kentucky: U.S. Geol. Survey Geol. Quad. Map GQ-1202, scale 1:24,000.

Klein, G. deV., 1974, Estimating water depths from analysis of barrier island and deltaic sedimentary sequences: Geology, v. 2, no. 8 , p. 409-412.

Krumbein, W. C., and Garrels, R. M., 1952, Origin and classification of chemical sediments in terms of $\mathrm{pH}$ and oxidation-reduction potentials: Jour. Geology, v. 60 , no. 1, p. 1-33.

Krumbein, W. C., and Sloss, L. L., 1963, Stratigraphy and sedimentation [2d ed.]: San Francisco, W. H., Freeman and Co., 660 p.

Kuenen, P. H., 1953, Significant features of graded bedding: Am. Assoc. Petroleum Geologists Bull., v. 37, no. 5, p. 1044-1066.

-1964, Deep sea sands and ancient turbidites, in Bouma, A. H., and Brouwer, A., eds., Turbidites: Amsterdam, Elsevier, p. 3-33.

Lane, N. G., 1973, Paleontology and paleoecology of the Crawfordsville fossil site (Upper Osagian: Indiana): California Univ. Pubs. Geol. Sci., v. 99, 141 p.,21 pls.

Lineback, J. A., 1966, Deep-water sediments adjacent to the Borden Siltstone (Mississippian) delta in southern Illinois: Illinois State Geol. Survey Circ. 401, 48 p.

1968a, Turbidites and other sandstone bodies in the Borden Siltstone (Mississippian) in Illinois: Illinois State Geol. Survey Circ. 425, 29 p.

1968b, Subdivisions and depositional environments of New Albany Shale (Devonian-Mississippian) in Indiana: Am. Assoc. Petroleum Geologists Bull., v. 52, no. 7, p. 1291-1303.

-1969, Illinois basin-sediment-starved during Mississippian: Am. Assoc. Petroleum Geologists Bull., v. 53, no. 1, p. 112-126.

McBride, E. F., 1962, Flysch and associated beds of the Martinsburg Formation (Ordovician), central Appalachians: Jour. Sed. Petrology, v. 32, no. 1, p. 39-91.
McBride, E. F., Weidie, A. E., and Wolleben, J. A., 1971, Deltaic origin of Difunta group (Late Cretaceous to Paleocene) Parras basin, Coahuila and Nuevo Leon, Mexico [abs]: Am. Assoc. Petroleum Geologists Bull., v. 55, no. 2, p. 352.

Martinsson, Anders, 1970, Toponomy of trace fossils, in Crimes, T. P., and Harper, J. C., eds., Trace fossils: Geol. Jour., Spec. Issue 3, p. 323-330.

Mathews, W. H., and Shepard, F. P., 1962, Sedimentation of Fraser River delta, British Columbia: Am. Assoc. Petroleum Geologists Bull., v. 46, no. 8, p. 1416-1443.

Meckel, L. D., 1970, Paleozoic alluvial deposition in the central Appalachians: a summary, in Fisher, G. W., Pettijohn, F. J., Reed, J. C., Jr., and Weaver, K. N., eds. Studies of Appalachian geology-central and southern: New York, Interscience Publishers, p. 49-67.

Meischner, K. D., 1964, Allodapische Kalke, Turbidite in Riff-nahen Sedimentations-Becken, in Bouma, A. H., and Brouwer, A., eds., Turbidites: Amsterdam, Elsevier, p. 156-191.

Moore, B. R., and Clarke, M. K., 1970, The significance of a turbidite sequence in the Borden Formation (Mississippian) of eastern Kentucky and southern Ohio, in Lajoie, J., ed., Flysch sedimentology in North America: Geol. Assoc. Canada Spec. Paper 7, p. 211-218.

Moore, G. T., and Asquith, D. O., 1971, Delta: term and concept: Geol. Soc. America Bull., v. 82, no. 9, p. 2563-2567.

Nicoll, R. S., and Rexroad, C. B., 1975, Stratigraphy and conodont paleontology of the Sanders Group (Mississippian) in Indiana and adjacent Kentucky: Indiana Geol. Survey Bull. 51, 36 p., $6 \mathrm{pl}$.

Passega, R., 1957, Texture as characteristic of clastic deposition: Am. Assoc. Petroleum Geologists Bull., v. 41, no. 9, p. 1952-1984.

1962, Problem of comparing ancient with recent sedimentary deposit: Am. Assoc. Petroleum Geologists Bull., v. 46, no. 1, p. 114-118.

Pepper, J. F., de Witt, Wallace, Jr., and Demarest, D. F., 1954, Geology of the Bedford Shale and Berea Sandstone in the Appalachian basin: U.S. Geol. Survey Prof. Paper 259, 111 p.

Peterson, W. L., 1966a, Geologic map of the New Haven quadrangle, Nelson and Larue Counties, Kentucky: U.S. Geol. Survey Geol. Quad. Map GQ-506, scale 1:24,000.

1966b, Geologic map of the Nelsonville quadrangle, central Kentucky: U.S. Geol. Survey Geol. Quad. Map GQ-564, scale 1:24,000.

1967, Geologic map of the Lebanon Junction quadrangle, central Kentucky: U.S. Geol. Survey Geol. Quad. Map GQ-603, scale $1: 24,000$.

1968, Geologic map of the Cravens quadrangle, Bullitt and Nelson Counties, Kentucky: U.S. Geol. Survey Geol. Quad. Map GQ-737, scale 1:24,000.

1972, Geologic map of the Loretto quadrangle, central Kentucky: U.S. Geol. Survey Geol. Quad. Map GQ-1034, scale 1:24,000.

Peterson, W. L., and Kepferle, R. C., 1970, Deltaic deposits of the Borden Formation in central Kentucky: U.S. Geol. Survey Prof. Paper 700-D, p. D49-D54.

Pettijohn, F. J. and Potter, P. E., 1964, Atlas and glossary of primary sedimentary structures: New York, Springer-Verlag, $370 \mathrm{p}$.

Phleger, F. B., 1951, Displaced Foraminifera faunas, in Turbidity currents and the transportation of coarse sediments to deep water-a symposium: Soc. Econ. Paleontologists and Mineralogists Spec. Pub. 2, p. 66-75.

Picard, M. D., 1971, Classification of fine-grained sedimentary rocks: Jour. Sed. Petrology, v. 41, no. 1, p. 179-195.

Piper, D. J. W., and Normark, W. R., 1971, Re-examination of a Miocene deep-sea fan and fan-valley, southern California: Geol. Soc. America Bull., v. 82, no. 7, p. 1823-1830. 
Potter, P. E., and Pettijohn, F. J., 1963, Paleocurrents and basin analysis: Berlin, Springer-Verlag, 296 p., 30 pls., and New York, Academic Press, 296 p.

Pryor, W. A., Klein, H. M., and Hannan, A. E., 1974, Crinoidal bodies of submarine-debris-flow origin, Early Mississippian, south-central Kentucky [abs.]: Am. Assoc. Petroleum Geologists and Soc. Econ. Paleontologists and Mineralogists Ann. Mtg. Abs., v. 1, p. 72-73.

Rich, J. L., 1950, Flow markings, groovings, and intra-stratal crumplings as criteria for recognition of slope deposits, with illustrations from Silurian rocks of Wales: Am. Assoc. Petroleum Geologists Bull., v. 34, no. 4, p. 717-741.

1951a, Three critical environments of deposition, and criteria for recognition of rocks deposited in each of them: Geol. Soc. America Bull., v. 62, no. 1, p. 1-19.

1951b, Probable fondo origin of Marcellus-Ohio-New Albany-Chattanooga bituminous shales: Am. Assoc. Petroleum Geologists Bull., v. 35, no. 9, p. 2017-2040.

Rich, J. L., and Wilson, W. J., 1950, Paleogeographic and stratigraphic significance of subaqueous flow markings in the Lower Mississippian strata of south-central Ohio and adjacent parts of Kentucky [abs.]: Geol. Soc. America Bull., v. 61, no. 12, pt. 2, p. 1496.

Rusnak, G. A., 1957, A fabric and petrologic study of the Pleasantview sandstone [Ill.]: Jour. Sed. Petrology, v. 27, no. 1, p. 41-55.

Ryan, W. B. F., and Heezen, B. C., 1965, Ionian Sea submarine canyons and the 1908 Messina turbidity current: Geol. Soc. America Bull. v. 76, no. 8, p. 915-932.

Sable, E. G., Kepferle, R. C., and Peterson, W. L., 1966, Harrodsburg Limestone in Kentucky: U.S. Geol. Survey Bull. 1224-I, 12 p.

Schultz, L. G., 1964, Quantitative interpretation of mineralogical composition from X-ray and chemical data for the Pierre Shale: U.S. Geol. Survey Prof. Paper 391-C, 31 p.

Sedimentation Seminar, 1969, Bethel Sandstone (Mississippian) of western Kentucky and south-central Indiana, a submarinechannel fill: Kentucky Geol. Survey, Ser. 10, Rept. Inv. 11, 24 p.

1972, Sedimentology of the Mississippian Knifley Sandstone and Cane Valley Limestone in south-central Kentucky: Kentucky Geol. Survey, Ser. 10, Rept. Inv. 13, 30 p.

Seilacher, Adolf, 1953, Studien zur Palichnologie; I. Über die Methoden der Palichnologie: Neues Jahrb. Geologie u. Paläontologie Abh., v. 96, no. 3, p. 421-452.

-1967 , Bathymetry of trace fossils: Marine Geology, v. 5, nos. 5-6, p. $413-428$.

Shepard, F. P., 1951, Transportation of sand into deep water, in Turbidity currents and the transportation of coarse sediments to deep water-a symposium: Soc. Econ. Paleontologists and Mineralogists Spec. Pub. 2, p. 53-56.

Simons, D. B., Richardson, E. V., and Nordin, C. F., Jr., 1965, Sedimentary structures generated by flow in alluvial channels, in Middleton, G. V., ed., Primary sedimentary structures and their hydrodynamic interpretation-a symposium: Soc. Econ. Paleontologists and Mineralogists Spec. Pub. 12, p. 34-52.

Smith, N. M., 1965, The Sanders Group and subjacent Muldraugh Formation (Mississippian) in Indiana: Indiana Geol. Survey Rept. Prog. 29, 20 p.

Stanley, D. J., and Huang, Ter-Chien, 1971, Multiple origin of hemipelagic mud fill in Mediterranean basin [abs.]: Am. Assoc. Petroleum Geologists Bull., v. 55, no. 2, p. 365.
Stockdale, P. B., 1931, The Borden (Knobstone) rocks of southern Indiana: Indiana Dept. Conserv., Div. Geology, Pub. 98, 330 p. 1939, Lower Mississippian rocks of the east-central interior: Geol. Soc. America Spec. Paper 22, 248 p.

Sullwold, H. H., Jr., 1960, Tarzana Fan, deep submarine fan of Late Miocene age, Los Angeles County, California: Am. Assoc. Petroleum Geologists Bull., v. 44, no. 4, p. 433-457.

1961, Turbidites in oil exploration, in Peterson, J. A., and Osmond, J. C., eds., Geometry of sandstone bodies-A symposium, 45th Ann. Mtg., Atlantic City, N.J., 1960: Tulsa, Am. Assoc. Petroleum Geologists, p. 63-81.

Suttner, L. J., and Hattin, D. E., eds., 1973, Field conference on Borden Group and overlying limestone units, south-central Indiana: Soc. Econ. Paleontologists and Mineralogists, Great Lakes Sec., 3d Ann. Mtg., Bloomington, Ind., 113 p.

Swann, D. H., Lineback, J. A., and Frund, Eugene, 1965, The Borden Siltstone (Mississippian) delta in southwestern Illinois: Illinois Geol. Survey Circ. 386, 20 p.

ten Haaf, Ernst, 1956, Significance of convolute lamination: Geologie en Mijnbouw, n. ser., v. 18, no. 6, p. 188-194.

Thaden, R. E., Lewis, R. Q., Sr., Cattermole, J. M., and Taylor, A. R., 1961, Reefs in the Fort Payne Formation of Mississippian age, south-central Kentucky: U.S. Geol. Survey Prof. Paper 424-B, p. B88-B90.

Thomson, A. F., 1971, Continuity of Pliocene turbidite sandstones, Ventura area, California, with applications to supplemental recovery [abs.]: Am. Assoc. Petroleum Geologists Bull., v. 55, no. 2, p. 366-367.

Visher, G. S., 1965, Use of vertical profile in environmental reconstruction: Am. Assoc. Petroleum Geologists Bull., v. 49, no. 1, p. 41-61.

Walker, R. G., 1967, Turbidite sedimentary structures and their relationship to proximal and distal depositional environments: Jour. Sed. Petrology, v. 37, no. 1, p. 25-43.

-1970 , Review of the geometry and facies organization of turbidites and turbidite-bearing basins, in Lajoie, J., ed., Flysch sedimentology in North America: Geol. Assoc. Canada Spec. Paper 7, p. 219-251.

Warshaw, C. M., and Roy, Rustum, 1961, Classification and a scheme for the identification of layer silicates: Geol. Soc. America Bull., v. 72, no. 10, p. 1455-1492.

Weir, G. W., 1970, Borden Formation (Mississippian) in southeastcentral Kentucky, in Geol. Soc. America, Southeastern Sec., 18th Ann. Mtg., Lexington, Ky., 1970, Guidebook for field trips: Lexington, Kentucky Geol. Survey, p. 29-48.

Weir, G. W., Gualtieri, J. L., and Schlanger, S. O., 1966, Borden Formation (Mississippian) in south- and southeast-central Kentucky: U.S. Geol. Survey Bull. 1224-F, 38 p.

Whitehead, N. H., III, 1973, The stratigraphy and sedimentology of the Floyds Knob bed and Edwardsville Member of the Muldraugh Formation (Valmeyeran), southern Indiana and northcentral Kentucky [abs.]: Geol. Soc. America, Abs. with Programs, v. 5, no. 5 (Southeastern Sec., 22d Ann. Mtg.), p. 450. -1976, The stratigraphy, sedimentology, and conodont paleontology of the Floyds Knob Bed and Edwardsville Member of the Muldraugh Formation (Valmeyeran), southern Indiana and north-central Kentucky: Urbana, Ill., Univ. Illinois, unpub. M.S. thesis, $443 \mathrm{p}$.

Wilson, W. J., 1950, Subaqueous flow markings in the Lower Mississippian strata of south-central Ohio and adjacent parts of Kentucky: Cincinnati, Univ. Cincinnati, unpub. M. S. thesis, 37 p. 